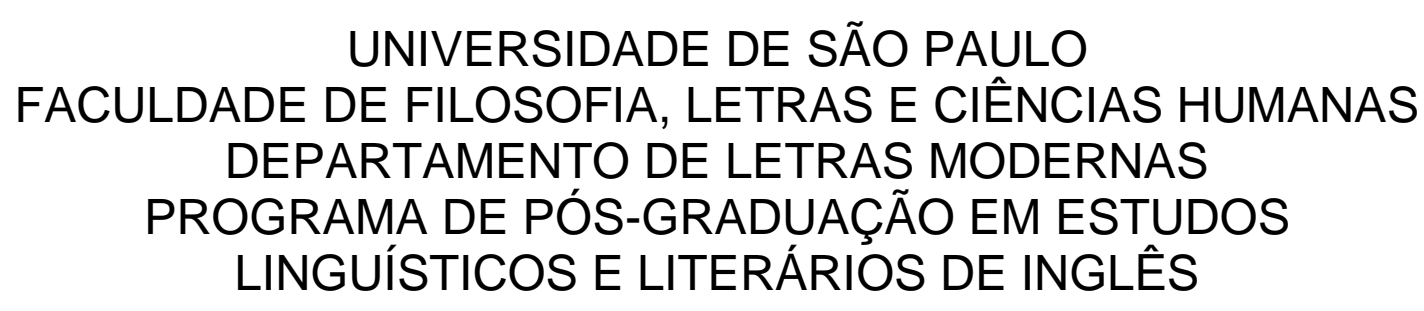

RUBERVAL FRANCO MACIEL

\title{
NEGOCIANDO E RECONSTRUINDO CONHECIMENTOS E PRÁTICAS LOCAIS: A FORMAÇÃO DE PROFESSORES DE LÍNGUA INGLESA E OS DOCUMENTOS OFICIAIS
}




\author{
UNIVERSIDADE DE SÃO PAULO \\ FACULDADE DE FILOSOFIA, LETRAS E CIÊNCIAS HUMANAS \\ DEPARTAMENTO DE LETRAS MODERNAS \\ PROGRAMA EM ESTUDOS LINGUÍSTICOS E LITERÁRIOS DE \\ INGLÊS
}

\title{
NEGOCIANDO E RECONSTRUINDO CONHECIMENTOS E PRÁTICAS LOCAIS: FORMAÇÃO DE PROFESSORES DE LÍNGUA INGLESA E OS DOCUMENTOS OFICIAIS
}

Ruberval Franco Maciel

Tese apresentada ao programa de Pósgraduação em Estudos Linguísticos e Literários de Inglês do Departamento de Letras modernas da Faculdade de Filosofia, Letras e Ciências Humanas da Universidade de São Paulo para a obtenção do titulo de doutor no programa de pós-graduação em Estudos Linguísticos e Literários em Inglês, sob orientação da Profa. Dra. Walkyria Monte Mór. 


\section{BANCA EXAMINADORA}

Profa. Dra. Walkyria Monte Mór (USP)

Presidente

Prof. Dr. Lynn Mario Trindade Menezes de Souza (USP)

Membro

Profa. Dra. Cláudia Hilsdorf Rocha (UNICAMP)

Membro

Profa. Dra. Nara Hiroko Takaki (UFMS)

Membro

Profa. Dra. Simone Bastista da Silva (UFRRJ)

Membro 
Dedico este trabalho às duas professoras colaboradas desta pesquisa que abriram as portas da escola e de suas casas para que eu pudesse ressignificar as minhas teorias, bem como a forma de ver a escola pública. 
"Sempre que os indivíduos julgam as coisas do mundo que Ihes são comuns, há implícitas em seus juízos mais que essas mesmas coisas". (ARENDT, 1954 [2009], p. 278) 


\section{AGRADECIMENTOS}

\section{Pessoais}

À minha orientadora, Professora Dra. Walkyria Monte Mór, pela sua postura, generosidade, confiança, cuidado e seu jeito elegante que the é peculiar de conduzir a orientação, sem imposições arbitrárias no processo da minha formação de pesquisador. Essa atitude contribuiu para que eu descobrisse caminhos não imaginados. Sua presença e seu agir profissional também me inspiram e me mantém atento para a importância da humildade acadêmica, generosidade e autocrítica em relação ao tratamento com os outros, que nem sempre compartilham as mesmas afinidades teóricas. Minhas sinceras gratidão e admiração!

Ao Professor Dr. Lynn Mário Menezes de Souza por fazer com que eu desaprendesse e reaprendesse conceitos e posicionamentos durante suas aulas e, com isso, pude desfazer de algumas amarras que não me permitiam ter outras percepções. Durante o período de doutorado, sentia-me muito honrado quando ele assistia minhas apresentações. Destaco a sua generosidade em dividir espaço em mesas redondas e por fazer comentários, sempre de forma sutil, após as apresentações em alguns congressos.

À Professora Dra. Diana Brydon por me receber como pesquisador visitante no Centro de Globalização e Estudos Culturais onde tive acesso ao acervo bibliográfico, espaço para desenvolver minha pesquisa. Além disso, ela forneceu valiosos comentários em minha produção acadêmica. Reconheço também a sua importância nesse processo por ser uma pessoa audível que também tinha interesse em aprender com o que eu trazia para a discussão.

Ao Bill Brydon pelo apoio técnico durante o processo de coleta de dados, bem como pela solução de questões burocráticas relativas à documentação e à 
hospedagem em Winnipeg no Canadá, bem como pelas preciosas filmagens e divulgação dos trabalhos que apresentei no Brasil e no Canadá.

À Professora Dra. Nara Hiroko Takaki pelas sugestões durante o exame de qualificação, bem como por sua parceria em projetos que nos possibilitaram negociar diferenças e rever condutas e posturas para que nossa colaboração pudesse se solidificar.

À Profa. Dra Vera Menezes de Oliveira e Paiva, a quem tenho muito respeito pelo seu trabalho acadêmico. Em uma conversa informal em Campo Grande me pegou de surpresa ao indagar: "Quando você vai fazer o seu doutorado?" e colocou-se a disposição para escrever uma carta de recomendação para bolsa Fullbright CAPES. Em seguida, verifiquei que o prazo já havia sido encerrado. Após alguns dias, enviou um e-mail sugerindo que eu devesse procurar a Profa. Dra. Walkyria Monte Mór, por ser a pessoa mais apropriada para orientar a temática da minha pesquisa. $O$ resultado deste gesto generoso fez grande diferença na minha formação acadêmica.

Aos colegas do programa pós-graduação em Estudos Linguísticos e Literários de Inglês da USP, em especial, à Andrea Mattos e à Ana Paula Duboc pela harmoniosa convivência durante o período de estágio de doutorado sanduíche em Winnipeg-Canadá em 2009/10. Andrea e sua família, companhias agradáveis nos momentos fora da universidade. Ana Paula com quem convivi mais diretamente e, com isso, aprendemos muito um com o outro durante esse tempo.

À secretária do programa de Pós-graduação, Edite Mendez $\mathrm{Pi}$, por sua competência na conduta de questões burocráticas do Departamento de Letras Modernas.

Às duas professoras que colaboraram com esta pesquisa.

Aos amigos Karla Costa, Fabríco Ono e Roseli Grubert pelas conversas bem humoradas, pelas trocas de experiências e pelas discussões acadêmicas. 
Aos colegas que participaram do grupo de estudo da Profa. Dra. Walkyria Monte Mór, bem como aos do grupo do Prof. Dr. Lynn Mario Menezes de Souza, com os quais aprendi muito na USP.

Aos demais colegas com os quais compartilhei questões acadêmicas e conversas valiosas. Com alguns, após as aulas, e outros, nos eventos acadêmicos: Luiz Henrique Magnani, Samara Marreiro, Renata Quirino, Vanderlei Zacchi, Flávia Benfatti, Marlene Souza, Simone Batista da Silva, entre outros.

Ao meu primo Fernando Franco Serpa por ter realizado as transcrições dos inúmeros encontros com as professoras e os alunos que participaram da pesquisa.

Ao Junior pelo apoio no processo final de revisão e formatação do trabalho.

\section{Institucionais}

À Universidade de São Paulo por possibilitar quatro anos de estudo de excelência.

À Universidade Estadual de Mato Grosso do Sul por me conceder licença remunerada para que eu pudesse me dedicar à pesquisa.

À FUNDECT (Fundação de Apoio ao Desenvolvimento do Ensino, Ciência e Tecnologia do Estado de Mato Grosso do Sul) por me conceder bolsa de estudo durante três anos.

Ao programa ELAP (Emerging Leaders in the Americas Programme) do governo canadense por me proporcionar bolsa para realizar o estágio doutorado sanduíche na Universidade de Manitoba no Canadá. 
Ao Centro de Globalização e Estudos Culturais da Universidade de Manitoba por me ceder espaço para estudo e acervo bibliográfico.

À Escola Estadual José Maria Hugo Rodrigues em Campo Grande, representada pelas diretoras Maria Aparecida Acosta e Marly Pedão Mina.

Ao SSHRC (Social Sciences and Humanities Research Council of Canada) que financiou alguns dos estudos e apresentações que realizei, por meio da participação no projeto Brazil-Canada Knowledge Exchange - developing transnational literacies, dirigido pela Profa. Dra. Diana Brydon, Universidade de Manitoba, Canadá. 


\section{SUMÁRIO}

INTRODUÇÃO

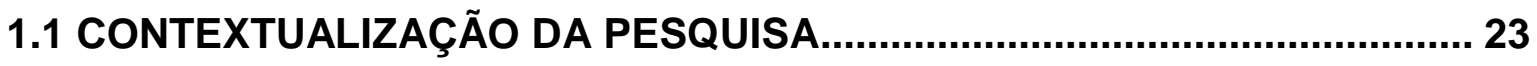

1.1.1 O desenho inicial e as mudanças ocorridas ............................................ 25

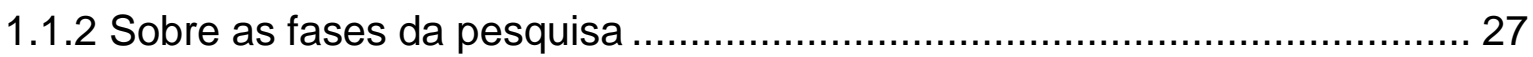

1.1.2.1 Primeira fase: (re) interpretação das propostas curriculares .................... 27

1.1.2.2 Segunda fase: negociação de conceitos para implementação................. 27

1.1.3 IDENTIFICAÇÃO DO CONTEXTO ESCOLAR ........................................ 30

1.1.3.1 Sobre as professoras colaboradoras ................................................. 31

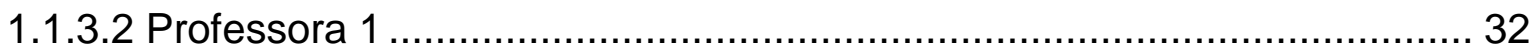

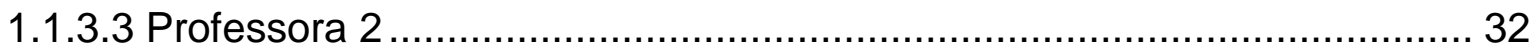

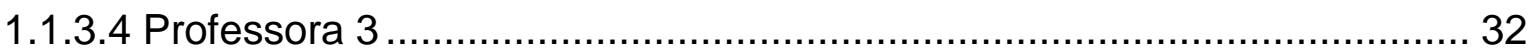

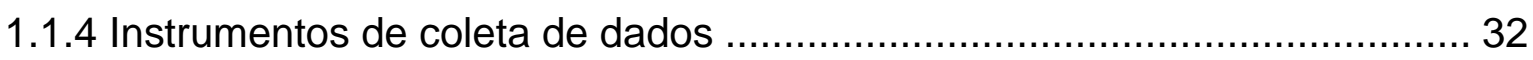

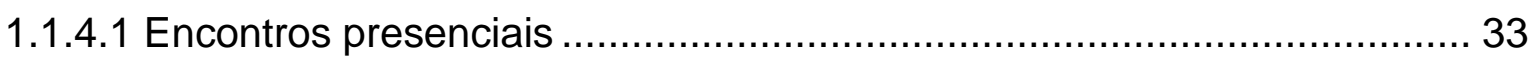

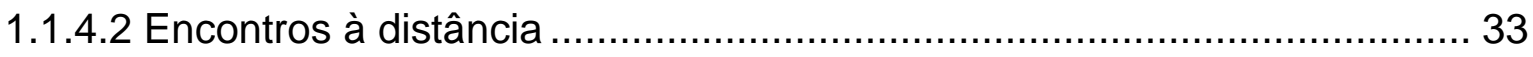

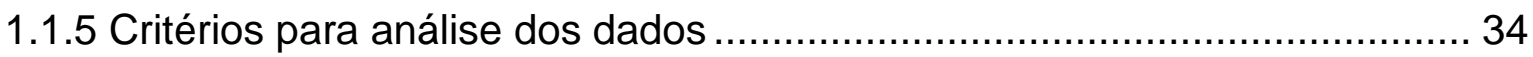

1.1.6 Procedimentos para análise dos dados ............................................... 34

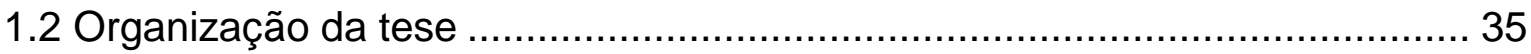

\section{CAPÍTULO I}

1. GLOBALIZAÇÃO, EDUCAÇÃO E FORMAÇÃO DE PROFESSORES DE

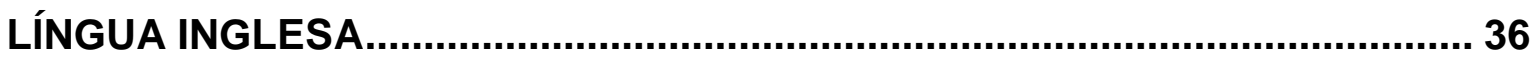

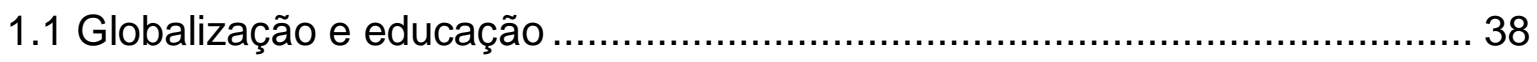

1.20 papel da língua inglesa como língua da globalização ............................... 45

1.3 A língua inglesa em uma sociedade globalizada e implicações para as

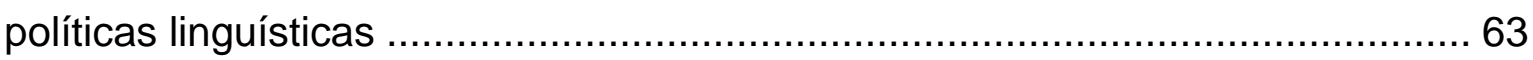

CAPÍTULO II

2. DOCUMENTOS CURRICULARES ORIENTADORES OU DESORIENTADORES DA PRÁTICA DO PROFESSOR DE LINGUA

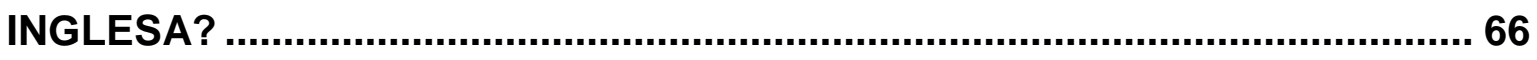

2.1 Políticas linguísticas e formação de professores de inglês ............................ 69 
2.3 O contexto escolar, os conflitos de objetivos e o ensino da língua inglesa em uma sociedade globalizada

\section{CAPITULO III}

3. SERÁ QUE EU SEI O QUE É BOM PRA VOCÊ?NEGOCIANDO E (RE) CONSTRUINDO POLÍTICAS LINGUISTICAS E CONHECIMENTOS LOCAIS.. 112

3.1 Referencial Curricular para o Ensino Médio: Língua Inglesa - Estado de Mato Grosso do Sul.

3.1.2 Orientações Curriculares para o Ensino Médio: Língua Inglesa (MEC)

3.20 conhecimento local

3.3 Será que ainda sei o que é bom pra você? A lógica de emancipação revisitada.

3.3.1 Emancipação e formação critica de professores

3.3.2 A lógica da emancipação revisitada

CONSIDERAÇÕES FINAIS

REFERÊNCIAS BIBLIOGRÁFICAS

ANEXOS

Anexo 1 Referencial curricular do Estado de Mato Grosso do Sul Anexo 2 Paralelo entre o Referencial Curricular do Estado de MS e as OCEM-MEC - Língua Inglesa 


\section{LISTAS DE FIGURAS}

Figura 1: Os três círculos propostos por Krachru .................................51

Figura 2: Slide apresentado pela professora 1 ..................................135

\section{LISTA DE TABELAS}

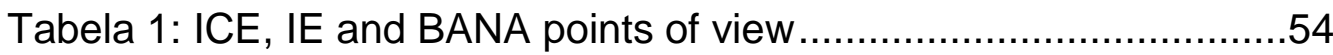

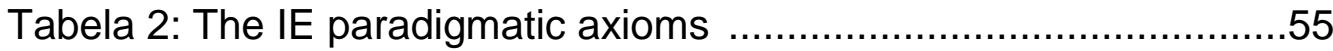

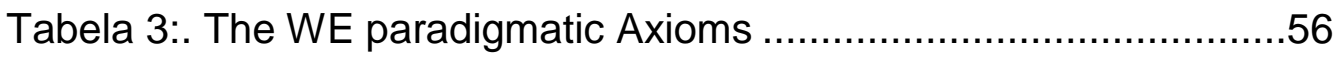

Tabela.4: The ELF paradigmatic axioms ..........................................

\section{LISTA DE ABREVIATURAS}

LE: Língua Estrangeira

MS: Mato Grosso do Sul

OCEM: Orientações curriculares para o Ensino Médio

PCN: Parâmetros Curriculares Nacionais

Convenções para apresentação dos dados e transcrições

[...] supressão

$P$ : pesquisador

P1: professora 1

P2: professora 2

P3: professora 3 


\section{RESUMO}

A presente pesquisa de natureza qualitativa com características colaborativa e etnográfica crítica buscou investigar a formação de professores de língua inglesa via dois documentos oficiais voltados para o segmento do ensino Médio (as Orientações Curriculares para o Ensino Médio - Língua Inglesa e o Referencial Curricular para o Ensino de Língua Inglesa do Estado de Mato Grosso do Sul). O trabalho fundamentou-se principalmente nos estudos sobre globalização, educação, letramentos, linguística aplicada, políticas linguísticas e filosofia. Por meio de um trabalho colaborativo de três anos com três professoras de inglês, os dados foram coletados de gravações em áudio dos momentos de interação entre o pesquisador e as professoras colaboradoras na fase de discussão dos documentos oficiais. Foram ainda utilizados nas análises dos dados um palestra proferida pelas professoras, entrevista, diário de campo gravação dos depoimentos dos alunos, bem como o depoimento da diretora da escola. A análise fundamenta-se principalmente nos seguintes enfoques abordados neste trabalho: a descrição do contexto de ensino aprendizagem na escola participante; a verificação do que a discussão dos documentos oficiais pode informar sobre a prática das professoras; a discussão do ensino da língua inglesa em uma sociedade globalizada; a verificação sobre o conhecimento local e reconstrução deste a partir de um trabalho colaborativo entre escola pública e universidade e, por fim, o debate sobe a lógica de emancipação revisitada na formação de professores.

Palavras-chave: formação de professores; políticas linguísticas; letramentos; globalização; ensino da língua inglesa. 


\begin{abstract}
The current research of qualitative nature with collaborative and critical etnography characteristics aimed at investigating teacher education based on two official documents both addressed to the high school segment (Orientações Curriculares para o Ensino Médio - Língua Inglesa; Referencial Curricular para o Ensino de Língua Inglesa do Estado de Mato Grosso do Sul). The work particularly focused on globalization, education, literacies, applied linguistics, language policy and philosophy. Under a three year collaborative work with three English teachers, data were gathered from audio recordings during the moments of interactions between the researcher and the teachers in the phase of document discussion. Furthermore, analyses have relied on lecturers delivered by the teachers, interviews, diaries and recordings of students' reports as well as the school principal's recorded reports. Analyses have addressed the following aspects raised in this study: Description of school teaching and learning contexts; investigation of what discussion of official documents can inform about teachers' practices; discussion of English language teaching in a globalized society; local knowledge reconstruction through the collaboration between public school and university and, lastly, the logic of emancipation was revisited in the analysis of teacher education.
\end{abstract}

Key words: teacher education, language policy; literacies; globalization; English language teaching. 


\section{INTRODUÇÃO}

Aluna: Bom [...] a minha experiência [...] eu comecei a aprender inglês [...] foi aqui na escola mesmo primeiro e tive uma experiência muito boa, gostei mesmo, a primeira ideia foi gostar mesmo do inglês e principalmente ter facilidade. Só que tem professores que estimulam nosso conhecimento e professores que estagnam a nossa vontade de aprender, agente acaba não criando curiosidade, vontade saber para a língua, e entrar em contato com o novo, com uma coisa que a gente não conhece é fantástico, principalmente se o professor sabe estimular isso. A [professora 2] começou a dar aula [...] a gente notou uma diferença bem drástica de uma professora para outra e ela tem um dinamismo muito bom e ela consegue mostrar pra gente onde o inglês é importante, e não só aprender a gramática, o que o componente curricular que o governo tá pedindo e sim mostrar que o inglês é útil, que a gente vê [...] entramos em contato com o inglês que é a linguagem mundial, então ela mostra que é necessário aprender inglês mas mais do que legal é útil pra nos e que pode enriquecer nosso conhecimento e que nos faz mais críticos.

Ela trabalha muito com as atualidades, coisas que estão acontecendo principalmente que estão dentro do nosso cotidiano, coisas que agente fala normalmente, textos que são sempre com temas que a gente convive [...] que a gente sabe e que agente tem contato. Nunca é uma coisa irreal ou que a gente não tem noção e sempre do cotidiano do que agente passa mesmo. Começa aqui na sala de aula e depois vai e depois vai ampliando. Ela sempre tenta assim [...] passar uma ideia inicial na sala de aula, com textos com uma proposta e depois ela leva pra sala de vídeo ou para a sala de informática, mostrando outras coisas: vídeos [...] Discuti muito e pede pra gente arriscar mesmo que agente não saiba muito, ela pede pra ariscar [....] no começo do ano ela pediu pra escrevermos um texto sobre nos mesmos, que é mais difícil do que até mesmo escrever em português e é difícil no inglês também, mas foi assim, foi um sucesso, as pessoas falando sobre si mesmas [...] a gente mostra o que agente entendeu [...]

Inicio esta tese com o depoimento de aluna de escola pública que

descreve com entusiasmo a sua experiência de aprender inglês, bem como a atuação de sua professora, fruto de um trabalho colaborativo entre escola pública e universidade. Com essa narrativa, convido o leitor desta tese a iniciar a reflexão a respeito dos estudos sobre formação de professores de língua inglesa. É bastante comum as pesquisas que investigam as escolas públicas brasileiras, bem como o discurso de grande parte da população brasileira, 
relatarem o lado negativo do ensino público. Busco aqui, inicialmente, ilustrar que a colaboração pode mostrar outros discursos, sobretudo em relação ao comprometimento de professores, bem como abordar suas angústias no processo de deslocamento de práticas locais, com base na negociação via documentos oficiais.

A presente pesquisa possui um caráter interdisciplinar com ênfase nos trabalhos da educação, pós-colonialismo, estudos sobre globalização, letramentos e políticas linguísticas. Esses enfoques têm apresentado fundamentos importantes para discutir educação na sociedade contemporânea. Embora tenham despertado interesses da área de linguística aplicada, são ainda relativamente pouco explorados no Brasil, no que se refere à formação de professores e ensino de línguas.

As investigações que se dedicam ao estudo das línguas estrangeiras e da formação de professores, durante muito tempo, deram ênfase às habilidades linguísticas, aos métodos e abordagens, aos aspectos formais e cognitivos da linguagem. Neste sentido, Cummins e Davison (2007) apontam que todos esses enfoques são aspectos importantes a ser considerados pelos legisladores e pelos educadores. No entanto, os autores observam que quando as questões técnicas ${ }^{1}$ de eficácia são analisadas de forma isolada dos contextos, dos propósitos e das políticas linguísticas, elas possuem poucas contribuições, pois reduzem o ensino de línguas a um conjunto de prescrições.

A tradição de pesquisa também se reflete na forma colonialista de como a linguística aplicada tem sido tratada por alguns conselhos editoriais de revistas especializadas. Nelas, os temas relacionados às questões críticas

\footnotetext{
${ }^{1}$ Ver Silva (2013), sobre a discussão de duas visões de formação: a técnica e o ensino crítico.
} 
sobre ensino de línguas são pouco contemplados. Neste aspecto, Kumaravadivelu (2006) afirma que tais profissionais beneficiam a visão tradicional do "centro" sobre língua, cultura e ensino. Como alternativa, o autor propõe uma mudança de foco do olhar moderno para as filosofias pósmodernas, que desafiam as hegemonias e buscam formas alternativas para expressão e interpretação. Essas considerações sobre a tradição de pesquisa me fazem refletir e buscar outras possibilidades sobre a pesquisa na formação de professores.

Um dos aspectos que me chamou atenção para complementar à discussão desta tese sobre a interface entre a formação de professores e as políticas linguísticas foi o conceito de conhecimento $\mid$ local $^{2}$, pois direciona o foco de pesquisa para questões situadas, conforme discuto mais adiante neste capítulo. Todavia, não busco aqui um aspecto inédito sobre teorias em si, ou ainda replicar estudos consolidados pela tradição de pesquisa. Proponho, no entanto, ressignificar os conceitos sobre conhecimento local que têm sido utilizados nos estudos culturais, nas questões identitárias e nas políticas linguísticas para reconceituá-las para a formação de professores.

Ressalto, ainda, que a investigação sobre o conhecimento local não é novo na academia e tem sido utilizado por várias áreas, principalmente nas ciências sociais e humanas, como nos estudos pós-coloniais, na política pública, na geografia humana e, mais recentemente, na linguística aplicada. Esses estudos, segundo Norton (2010), receberam uma grande contribuição

\footnotetext{
${ }^{2}$ Outros autores como Bhabha e Menezes de Souza, por exemplo, preferem adotar o conceito de conhecimento contextual. Canagarajah (2005) afirma que o conhecimento local também pode ser chamado de contextual, conforme utilizado por Bhabha e Menezes de Souza. Para esta tese, mantenho o conceito de conhecimento local.
} 
dos etnógrafos, devido à impossibilidade de separar o conhecimento de seu contexto e processo de construção de significados em relação a fatores sociais, econômicos e políticos que moldam a prática social. Para Norton (opt. cit., p. 8), o conhecimento local refere-se às "maneiras de saber pelas quais as pessoas negociam seus próprios termos que estão tipicamente fora das fronteiras dos paradigmas aceitáveis ou dominantes", fundamentados pela familiaridade pessoal e derivado de experiência vivida.

Na esfera da linguística aplicada, Canagarajah (2002, 2005, 2006) aponta que o empirismo inspirado pelo iluminismo levou a uma crise do conhecimento local e que "o modernismo estabeleceu redes de trabalhos geopolíticos e uma economia mundial que incentiva a divisão de vida e, com isso, todas as comunidades são pressionadas a uma marcha de uniformização para obtenção do progresso" (2002, p. 245). Essa visão de avanço favorece o conhecimento ocidental como sinônimo de conhecimento global, colocando o conhecimento local em segundo plano, através de um processo de hibridação e adaptação. Deste modo, associo o aspecto abordado por Canagarajah sobre padronização, aos modelos eurocêntricos de formação de professores, com base em métodos e em prescrições de competências, seguindo um modelo de língua e linguagem que privilegiam variantes e noções de culturas e ideologias de países do norte.

Nesse sentido, Canagarajah (2005), Kumaravadivelu (2006) e Rajagopalan (2004) referem-se à exportação de metodologias para o ensino de língua inglesa conforme o modelo ocidental europeu e norte americano de produção e disseminação de materiais do centro para a periferia, como uma forma de continuação do imperialismo ocidental. As pesquisas com base nas 
filosofias pós-coloniais, no entanto, questionam essa supremacia e abrem espaço para desconstruir do modelo do falante nativo e para repensar a aplicação de metodologias que privilegiam o modelo de ensino de língua e cultura influenciado pela visão ocidentalizada que busca homogeneizar as práticas locais.

Neste mesmo raciocínio, o aspecto de natureza contraditória, gerado pelo efeito da globalização, é reconhecido por teóricos da globalização e pós-colonialistas. Appadurai (2000), por exemplo, afirma que o problema central das interações globais são as tensões entre a homogeneização e heterogeneização cultural. Como contra discurso, Mignolo (2000) sugere o conceito de 'border thinking', ou seja, outra maneira de pensar, que visa o deslocamento dos modelos considerados universalmente válidos nas perspectivas eurocêntricas e ocidentais. Embora Appadurai e Mignolo não se refiram diretamente ao aspecto educacional, suas discussões podem ser ressignificadas para a formação de professores de línguas estrangeiras para compreender o aspecto mais macro relacionado à língua.

Ainda sobre o conceito de conhecimento local, os primeiros trabalhos sobre letramentos abordaram esse aspecto nas primeiras investigações sobre letramento oral (Gee, 1990). Na última década, essa perspectiva foi abordada na difusão das pesquisas lideradas pelo New London Group e suas preocupações educacionais, relatados nos trabalhos de Gee (2003), Kress (2004), Cope e Kalantzis (2000), Lankshear e Knobel (2003) e, mais anteriormente, Street (1995). O conhecimento local também pode ser associado ao trabalho sobre hip hop de Pennycook (2007). O autor aponta para uma perspectiva global, transcultural em defesa da inclusão do conhecimento 
local sob a forma de 'hiphopgrafia'. Esse movimento demonstra as possibilidades de inserção de alunos em práticas de letramento em comunidades marginalizadas, mas também não se limita exclusivamente ao universo da escola.

Além disso, o silenciamento do aspecto local é reforçado pelas políticas públicas influenciadas pelo discurso da globalização. Sobre esse aspecto, Hoveid e Hoveid (2008, p. 127) criticam que "os conceitos neoliberais e o pensamento instrumental defendem que a qualidade na educação seja concebida como algo a ser primariamente garantida pela avaliação dos alunos em testes de habilidades com foco em objetivos e resultados." Essa visão tende a reduzir a educação a algo onde as soluções técnicas são mais valorizadas e onde tem mais possibilidade de serem adotadas.

Em busca de um desenho de pesquisa que leve em consideração a complexidade das políticas públicas para o ensino de línguas no Brasil e na formação de professores, optei por uma metodologia de pesquisa de caráter qualitativo. As pesquisas qualitativas de formação de professores, conduzidas na sala de aula, segundo Cummins e Davison (op. cit., p. 964), tipicamente enfocam "os comportamentos instrucionais, os modelos de interações entre professores e alunos, os processos de ensino-aprendizagem, os resultados associados com diferentes tipos de linguagem e atividades de letramento", ou seja, direcionam para os aspectos observáveis e, até mesmo mensuráveis por um pesquisador externo. Há, neste sentido, uma relação dialética entre sujeito e objeto, bem como a comprovação de hipóteses pré-estabelecidas pelo pesquisador. $\mathrm{O}$ trabalho proposto às professoras, nesta pesquisa, possui uma relação dialógica e isso tem contribuído para rever minha formação tradicional 
de formação de professores seguindo um modelo mais ortodoxo de emancipação.

Uma das características da pesquisa qualitativa, segundo Duff (2007) é sua possibilidade de explorar perspectivas e interpretações internas, ao invés de apenas confiar no que pode ser observado ou mensurado do lado de fora, como em paradigmas de pesquisas mais tradicionais. Professores como participantes internos em relações educacionais têm o potencial de "ver do lado de dentro" esses relacionamentos. Seus olhares de dentro não podem ser duplicados por aqueles que estão em uma posição externa, como é geralmente o caso dos pesquisadores externos. Por outro lado, durante o processo, podem surgir questões que não eram aparentes, mas potencialmente identificáveis por aqueles que estão distanciados. Nesse sentido, Duff (op. cit.) aponta que a pesquisa qualitativa tem o potencial de unir as micro e as macro análises, as perspectivas de dentro e de fora sobre as questões de determinados fenômenos que, de outra perspectiva, não seriam observáveis.

A presente pesquisa também apresenta características da etnográfica crítica. Neste sentido, Canagarajah (2009) aponta que a pesquisa etnográfica para o estudo das políticas linguísticas pode desenvolver teorias que informem como a língua é praticada em contextos localizados, demonstrando, assim, o ponto de vista da própria comunidade num nível micro. Neste raciocínio, esta pesquisa não adota a visão positivista racional dominante que norteia as políticas de planejamento linguístico, baseadas nos objetivos das necessidades, processos e produtos. Desenvolver pesquisa informada pela etnografia, por outro lado, pode informar sobre o conhecimento local do professor, tais como as experiências, o cotidiano da sala de aula, a formação 
acadêmica, bem como verificar o que pode emergir quando uma proposta curricular institucional entra em contato com esse conhecimento local.

O interesse em investigar a formação de professores por meio das políticas públicas para o ensino da língua inglesa tem sido objeto de pesquisa desde o meu estudo de mestrado sobre implementação de inovação curricular. O termo inovação (Maciel, 2001) que utilizei na pesquisa anterior foi ressignificado para esta pesquisa para conceito de política crítica de línguas, com base em Pennycook (2009). O foco no tema também se justifica pelo atual processo de 'fast policymaking', termo apresentado por Rizvi e Lingard (2010), para descrever o que tem acontecido nas políticas educacionais numa escala global. Esse processo pode ser identificado no contexto brasileiro pelo lançamento de várias propostas curriculares, sem o devido investimento na formação de professores, transformando-se, assim, em políticas simbólicas.

Com o lançamento de vários documentos direcionados para o mesmo segmento, os professores de língua inglesa se depararam com novos e velhos conceitos, tais como competências e habilidades, referenciais curriculares, letramentos, letramento crítico, multimodalidade, gramática, vestibular, globalização, cosmopolitismo, sequência didática, abordagem comunicativa, gêneros textuais, listas de conteúdos prescritivos, documentos abertos para reinterpretação local, entre outros aspectos. Embora os documentos oficiais visem nortear o planejamento dos professores, com mais ou menos controle, as implicações de tais propostas não têm sido foco de investigação na formação de professores de línguas, dado o número reduzido de dissertações e teses, bem nos temas dos grupos de pesquisa sobre essa temática e nas publicações de revistas especializadas da área. 
A partir dessas considerações iniciais proponho, por meio desta pesquisa, responder aos seguintes questionamentos:

1) Qual é o contexto de ensino e aprendizagem da escola participante da pesquisa?

2) $\mathrm{O}$ que a interpretação de dois documentos oficiais pode informar sobre a prática dos professores de inglês?

3) $\mathrm{O}$ que as discussões com as professoras revelam sobre o ensino da língua inglesa para uma sociedade globalizada?

4) De que maneira o conhecimento local pode ser reconstruído a partir da colaboração na implementação de documentos oficiais?

A partir dessas questões, busco investigar um processo colaborativo na negociação e reconstrução dos conhecimentos locais a partir de documentos oficiais. Mais especificamente, com esse estudo proponho identificar o contexto de ensino de língua inglesa no ensino médio da Escola Estadual J. M. H. R.; verificar a influencia da globalização na discussão sobre o ensino da língua inglesa na escola investigada; investigar os objetivos das professoras em relação ao ensino da língua inglesa no segmento do ensino médio e analisar o processo de negociação e reconstrução dos conhecimentos das professoras para o contexto local a partir dos documentos oficiais.

Para tanto, proponho uma investigação de natureza qualitativa, com aspectos da etnografia crítica, conforme descrevo a seguir.

\subsection{CONTEXTUALIZAÇÃO DA PESQUISA}

A presente pesquisa, de natureza qualitativa, possui característica etnográfica, com ênfase na perspectiva colaborativa interpretativa. Esta 
escolha, segundo Heigham e Sakui (2010, p. 93), permite ao pesquisador "explorar como as pessoas criam, sustentam, mudam e transmitem seus valores compartilhados, crenças e comportamentos." Associo a esse conceito o trabalho de investigar o processo de leitura e interpretação de dois documentos oficiais e a prática da sala de aula a partir de um trabalho colaborativo.

Ao me referir à característica etnográfica, não adoto para essa pesquisa a versão da etnografia tradicional que possui um grande foco na cultura do grupo, no desconhecido, no 'exótico', que considera a característica local sem interferir no processo, mudando gradativamente do contexto desconhecido e passando a considerar o conhecido. Com base em Heigham e Sakui (2010), refiro-me a outra possibilidade cuja perspectiva tradicional foi revisitada, passando por uma espécie de 'metamorfose' da visão clássica, para a incorporação de outras possibilidades como a etnografia crítica, a etnografia feminista, a etnografia focada, a etnografia confessional, a auto-etnografia, a etnografia virtual, entre outras.

Assim, para este trabalho, aproprio-me do conceito de etnografia crítica, conforme apontado por Angrosino (2007), por representar uma descrição mais próxima à característica do trabalho aqui apresentado. $\mathrm{O}$ pesquisador, nessa visão, considera os pequenos grupos que não estão fisicamente em uma mesma localização, mas que compartilham características particulares e se comunicam por meio de ferramentas online. Associo essa questão de característica e localização à escola, cujo grupo de professores está inserido num mesmo espaço institucional, com suas identidades teóricas distintas e que atuam em diferentes contextos de salas de aula e, no caso desta pesquisa, norteados por um mesmo documento oficial. Ao invés de grupo 
investigado, utilizo o conceito de comunidade investigada, por descrever melhor a complexidade dos participantes da pesquisa. Logo, a noção de comunidade não se amplia para todos os participantes da escola, mas apenas às professoras engajadas no trabalho colaborativo.

Nesse processo, destaco o papel da autocrítica como aspecto importante aos objetivos do etnógrafo. Para Menezes de Souza (1992) apud Takaki (2011, p. 33), a autocrítica é "a capacidade de avaliar suas próprias lentes culturais que influenciam a leitura dos processos e dos resultados de uma determinada pesquisa." Com isso, a incompletude e as mudanças fazem parte do repertório do etnógrafo que considera as vicissitudes do processo de negociação das interpretações e da prática do professor.

\subsubsection{O desenho inicial e as mudanças ocorridas}

A pesquisa no seu desenho inicial objetivava propor um curso de formação continuada, com apoio da Associação de Professores de Mato Grosso do Sul (APLIEMS), direcionado aos professores de escolas estaduais do ensino médio de Campo Grande-MS. O referido curso buscaria sensibilizar os professores sobre aspectos relacionados ao papel da língua inglesa no ensino médio, para posteriormente propor um segundo curso destinado a professores voluntários para se discutir os documentos oficiais visando a ressignificação para o contexto local, conforme anteriormente exposto na justificativa. No entanto, no início de 2009, uma professora, da Escola Estadual J. M. H. R. na cidade de Campo Grande-MS, ao tomar conhecimento de que haveria a proposta de um curso de formação continuada, colocou-se a disposição para um trabalho específico com sua escola. 
Após esse contato inicial, a professora reuniu-se com todos os professores da disciplina de língua inglesa, bem como com a direção da escola para verificar o interesse na participação do projeto. Porém, antes da finalização dos trabalhos do ano letivo de 2008, já havia sido realizada uma reunião com todos os professores lotados na disciplina de língua Inglesa da escola, bem como com a vice-diretora. Naquele momento, todos demonstraram interesse e mencionaram que a proposta só poderia ser viabilizada se houvesse disponibilidade no horário de planejamento dos professores. Foi sugerido, então, que os encontros poderiam ocorrer no dia do planejamento quinzenal às segundas-feiras.

Sendo assim, no início do ano letivo de 2009, dos cinco professores que estavam presentes na reunião do ano anterior, três se voluntariaram devido à compatibilidade de horário. Os encontros aconteceriam conforme combinado na reunião de 2008. Como eu ministrava aulas em um campus universitário localizado no interior do estado de Mato Grosso do Sul, essas reuniões foram renegociadas para encontros individuais e coletivos conforme disponibilidade do grupo. Após dois meses de trabalho, uma das participantes, por motivos de saúde, licenciou-se e definiu-se, então, o número de participantes em duas professoras colaboradoras. A seguir, descrevo: 1) as fases da pesquisa, bem como 2) identificação do contexto escolar e, por fim, 3) Os instrumentos de coleta de dados, os encontros presenciais e à distância, os procedimentos para a análise dos dados, bem como a organização da tese. 


\subsubsection{Sobre as fases da pesquisa}

O estudo foi composto por duas fases principais. A primeira referese à identificação do contexto escolar e a interpretação dos documentos e a segunda relaciona-se à negociação das teorias e reinterpretação para o contexto local, conforme descrito a seguir.

\subsubsection{Primeira fase: (re) interpretando as propostas curriculares}

Durante a primeira fase foram realizados encontros para discutir dois documentos oficiais para o segmento do ensino médio: os Referenciais Curriculares para o Ensino de Língua Inglesa do estado de Mato Grosso do Sul e as Orientações Curriculares para o Ensino Médio-Língua Estrangeira (OCEMLE) - língua inglesa, propostas pelo Ministério da Educação. Essa fase teve início em março de 2009 e término em agosto de 2009. O principal foco foi verificar a percepção das participantes em relação aos dois referidos documentos oficiais e como as minhas percepções teóricas poderiam interferir no contexto em questão. As análises dos documentos oficiais serão apresentadas mais adiante nos capítulos 1 e 2 .

\subsubsection{Segunda fase: negociação de conceitos para implementação}

Esta fase ocorreu no período de setembro a dezembro de 2009. Durante esse período, retomamos alguns conceitos dos documentos oficiais como, por exemplo, novos letramentos, multiletramentos, local/global, inclusão/exclusão, competências e habilidades e os conteúdos prescritos, entre outros aspectos. A partir das discussões, demos início a um processo de aplicação de alguns projetos temáticos, que refletiam os dois documentos lidos, 
após a reinterpretação desses para o contexto local. A pesquisa foi desenvolvida em cinco salas de primeiro ano e duas turmas de segundo ano do ensino médio, dos períodos matutino e vespertino durante o segundo semestre de 2009.

No ano seguinte, a proposta foi ampliada para todas as turmas do ensino médio dos dois períodos em que as professoras participantes ministram aulas. Durante o ano de 2010, não houve acompanhamento direto das atividades como ocorreu no ano anterior. Essa medida foi tomada com o objetivo de promover a agência das professoras e, ao mesmo tempo, evitar eventuais interferências do pesquisador como 'um processo emancipatório de forma vertical'. No entanto, visando dar continuidade ao trabalho colaborativo entre o pesquisador e as professoras pesquisadas, foram realizados encontros mensais no primeiro e no segundo semestre. Esses encontros ratificaram o interesse das professoras que estavam em período de elaboração das atividades. Nesse, discutia-se o cumprimento do referencial curricular de MS, embora de forma diferenciada, contemplando as necessidades locais da comunidade envolvida. Foram trabalhados temas que possibilitavam contemplar atividades sobre o letramento crítico, conforme discuto no capítulo 3, entre outros aspectos sugeridos nas OCEM-LE, sendo este um dos documentos analisados nesta investigação.

Para essa fase colaborativa, realizamos encontros [as mencionadas professoras e o investigador] sob a forma de vídeo conferência semanal via skype e MSN. A utilização dessas ferramentas se deve ao fato de que eu estava como bolsista no Centro de Globalização e Estudos Culturais da Universidade de Manitoba - Canadá, o que demandou a utilização de recursos 
tecnológicos síncronos para a viabilização de nossa comunicação e do processo de coleta de dados. Os encontros foram gravados e transcritos, totalizando 500 páginas de transcrição de dados. Essa experiência me remete à discussão de Edward e Usher (2008) sobre os trabalhos colaborativos e o uso de tecnologias digitais. Os autores mencionam que o século $X X I$ é marcado pela complexidade e pela natureza em rede das interações. Essas demandam, cada vez mais, colaborações, levando-se em consideração as necessidades de comunidades específicas. Assim, por meio do ciberespaço, os participantes não mais necessitam estar num mesmo local, mas potencialmente disponíveis em uma escala nacional ou global. Em outras palavras, embora eu estivesse no Canadá a estudo e as professoras colaboradoras no Brasil, isso não representou um impedimento para a continuidade do cronograma proposto, pois a comunicação mediada com a utilização de recursos tecnológicos permitiu a interação síncrona durante quatro meses.

Após os dados coletados sobre a interação com as professoras, houve a segunda fase da pesquisa: para cada contexto (sala de aula) de aplicação do projeto foram entregues cinco diários para que os alunos do ensino médio relatassem, ao final das aulas, as suas percepções sobre o processo de aprendizagem nas aulas. Além dos diários, no final do semestre letivo, foram realizadas entrevistas para retomar alguns aspectos que não foram explicitados nas narrativas presentes nos diários.

No final do ano 2010, novas entrevistas foram realizadas com alunos das duas professoras participantes do projeto. Inicialmente não seria considerada a inclusão desses dados na pesquisa [participação desses 
alunos]. No entanto, a partir do andamento do processo colaborativo com as professoras, verificamos a necessidade de incluir os relatos dos alunos sobre as proposições das atividades. Os relatos indicaram que os alunos perceberam mudanças significativas na aprendizagem com a aplicação da proposta pedagógica, bem como no aspecto de formação crítica, proporcionada pela escolha dos temas apresentados, conforme discuto nesse trabalho.

\subsubsection{IDENTIFICAÇÃO DO CONTEXTO ESCOLAR}

A pesquisa foi desenvolvida em uma escola da rede estadual de ensino do Estado de Mato Grosso do Sul, situada em região periférica da cidade de Campo Grande-MS. A escola atende a um total de 1.600 alunos e, por isso, é considerada a segunda escola na capital de MS em número de alunos, distribuídos no ensino fundamental e médio. Com relação à estrutura física, a escola tem 6.750 metros quadrados, sendo 2.470 metros de área construída, das quais dispõe de vinte e seis salas de aula, duas quadras cobertas, uma biblioteca não informatizada, uma sala áudio visual equipada apenas com vídeo e aparelho de CD, um laboratório de informática com vinte e seis computadores.

Verifica-se que na escola, a disponibilidade da única sala de tecnologia depende do agendamento prévio do professor. Para as aulas de língua inglesa, as professoras dispõem de uma sala convencional de carteiras organizadas em filas e recursos tais como lousa, giz e retroprojetor. Quando há necessidade de uso de áudio e vídeo, os alunos são encaminhados para a sala de vídeo. Na ocasião da pesquisa, a escola pública não dispunha de livros didáticos para a disciplina de língua inglesa, uma vez que ainda não havia sido 
contemplada pelo Plano Nacional do Livro Didático (PNLD), embora ofereça esse material para a maioria das outras disciplinas do currículo.

\subsubsection{Sobre as professoras colaboradoras}

Descrevo, a seguir, o perfil das professoras participantes da pesquisa, com relação à formação acadêmica, os contextos educacionais, bem como a carga horária de trabalho semanal.

\subsubsection{Professora 1}

A professora graduou-se em Letras no ano de 2004 e concluiu o curso de especialização em Língua Inglesa em 2006. Pertence ao quadro de professores efetivos da Secretaria Estadual de Educação do Estado de Mato Grosso do Sul e possui uma carga-horária de vinte horas de trabalho semanais. Além disso, no início dessa pesquisa em 2009, a professora também ministrava aulas na rede particular no segmento do ensino fundamental e médio orientado com material apostilado. Aos sábados a professora frequentava um curso livre de língua inglesa.

Os dados iniciais apontam que havia conflitos de objetivos da professora em relação à função da língua inglesa na escola pública e particular. As narrativas também evidenciaram que a professora verificava haver mais empenho dos alunos na escola particular. No entanto, no segundo ano da pesquisa, a professora optou por trabalhar apenas no contexto público e assumiu aulas na sala de tecnologia, lotando-se, assim, em 40 horas aula de contrato na escola da rede estadual. 


\subsubsection{Professora 2}

Graduou-se em Letras no ano 2000 e em 2009, no primeiro ano da pesquisa, estava em fase de conclusão de um curso de especialização em língua inglesa. Pertence ao quadro de professores efetivos da Secretaria Estadual de Educação do Estado de Mato Grosso do Sul, com carga-horária de vinte horas-aula semanais. Além disso, a professora também ministrava outras vinte aulas no ensino fundamental da rede municipal de Campo Grande. No período noturno a professora ministrava aulas em um curso livre de língua inglesa. A partir do segundo ano da pesquisa a professora também optou por trabalhar apenas na rede pública.

\subsubsection{Professora 3}

Esta professora, por problemas de saúde, não participou da segunda fase da pesquisa. Porém, as narrativas da participação da professora nos primeiros encontros são consideradas na análise e discussão dos dados.

\subsubsection{Instrumentos de coleta de dados}

A pesquisa transcorreu em duas fases principais. A primeira foi

realizada com encontros presenciais no primeiro semestre de 2009 , e a segunda com encontros online durante o semestre seguinte. Após essas duas fases, houve encontros presenciais esporádicos. Durante esses períodos, os seguintes instrumentos de coleta de dados foram utilizados. 


\subsubsection{Encontros presenciais}

Durante os meses de março a junho de 2009, foram realizados encontros semanais, para a discussão dos objetivos do ensino da língua inglesa no ensino médio, e posteriormente a leitura dos dois documentos oficiais (estadual e nacional) para o segmento do ensino médio. Para a realização da pesquisa, foram estabelecidos encontros presenciais e a distância, utilizando-se assim, diferentes instrumentos de coleta de dados. Essas reuniões foram gravadas em áudio e transcritas.

\subsubsection{Encontros à distância}

Durante os meses de setembro a dezembro de 2009, em função do período de estágio sanduíche no Centro de Globalização e Estudos Culturais na universidade de Manitoba no Canadá, foram realizadas teleconferências, com característica da etnografia virtual, utilizando-se as ferramentas MSN e Skype, como opção para a realização das interações síncronas à distância. No total foram transcritas dezesseis horas de gravações.

O MSN palavra, abreviação de The Microsoft Network, é uma das ferramentas da Microsoft utilizada para capturar sons e imagens na comunicação pelo meio virtual e permite que vários usuários interajam ao mesmo tempo em tempo real. Essa ferramenta geralmente é utilizada para a comunicação e o entretenimento e não possui custos de ligação para o usuário. Foi escolhida por apresentar familiaridade de uso entre os participantes. Esse aspecto ligado a netnografia possibilitou que pudéssemos estar em vários locais, sem que a pesquisa fosse interrompida ou que houvesse problemas de se estabelecer comunicação regularmente. 


\subsubsection{Critérios para análise dos dados}

Para a análise das questões que emergiram durante o processo colaborativo, recorro a uma perspectiva qualitativa interpretativa, com base na filosofia pós-estrutural. Nesse sentido, não é o objetivo dessa tese identificar a essência de um determinado fenômeno sob investigação. Ao contrário, a representação neste trabalho será vista como necessariamente incompleta, uma premissa que representa uma ética para lidar com a interpretação. Assim, Cilliers (2003) também sugere que as narrativas sejam analisadas com 0 cuidado de uma interpretação como um processo inacabado e complexo. Com base em Kuntz (2010, p. 424), interpreto que da mesma forma que as teorias pós-estruturalistas de linguagem e identidade sugerem que "nossas identidades estão sempre em processo, na medida em que negociamos as narrativas de nossas instituições sociais", a pesquisa também precisa refletir esse processo. Em outras palavras, são as narrativas que definem e redefinem os objetivos, as hipóteses, as escolhas teóricas, bem como o recorte para análise, sempre em um processo inacabado.

\subsubsection{Procedimentos para análise dos dados}

Para situar o leitor, utilizarei a letra $\mathrm{P}$ para me referir a minha participação como pesquisador e as letras P1 e P2 para indicar as narrativas da professora 1 e da professora 2, respectivamente. Optei por não criar pseudônimos, pois me sinto incomodado como leitor de atribuir ao outro nome às participantes uma vez que houve um envolvimento profissional e comprometimento entre os nossos trabalhos. Embora a professora 3 não tenha 
feito parte das discussões até o final da primeira fase, utilizarei a abreviação P3 para registrar a contribuição da referida professora.

\subsection{Organização da tese}

Este trabalho apresenta-se organizado em três capítulos. Inicialmente a introdução busca situar o leitor sobre o desenho da pesquisa, bem como descrever a comunidade investigada e apresentar os dois documentos oficiais que norteiam a discussão dos encontros com as professoras. O primeiro capítulo expõe uma fundamentação teórica sobre a interface da globalização com a educação e o ensino da língua inglesa. $O$ capítulo dois descreve o contexto escolar, bem como a percepção das professoras sobre o objetivo de ensinar a língua inglesa no ensino médio. 0 capítulo três discute os dois documentos oficiais para o ensino médio e a sua relação para a prática das professoras. Aborda, ainda, a formação de professores com ênfase no conceito de conhecimento local via documentos oficiais. Por fim, o capítulo revisita o termo emancipação e formação crítica de professores de inglês.

Por meio desse estudo, reitero a minha expectativa de contribuição para a área de letramentos, ensino de línguas e formação docente. Entendo que essa pode ser identificada na relevância dos dados e análises que refletem o conhecimento local, a formação dos professores participantes e a motivação destes diante das mudanças pessoais, pedagógicas e profissionais num momento social e histórico que requer transformações. Saliento ainda que, como pesquisador, professor, cidadão e pessoa interessada nessa área e outras afins, observo um processo de mudança em minha própria perspectiva, construída ou reconstruída ao longo do trajeto da pesquisa. 


\title{
CAPÍTULO I
}

\section{GLOBALIZAÇÃO, EDUCAÇÃO E FORMAÇÃO DE PROFESSORES DE LÍNGUA INGLESA}

\begin{abstract}
P1: Nós temos desafios [...] os problemas que nós temos em sala de aula, que o nosso aluno, ele está diferente, ele está com outro perfil, ele é... justamente pela globalização, pelas novas tecnologias de informação, até pelas mudanças ocorridas na nossa sociedade, a gente vê que o nosso aluno está diferente.
\end{abstract}

O relato da professora acima em relação às mudanças no perfil de aluno acentuadas pela globalização e pelas novas tecnologias de informação, bem como a sua angústia acentuada pelo distanciamento entre a realidade da escola e do cotidiano dos alunos foram as primeiras questões que emergiram nesta pesquisa. Sobre esse assunto, vários autores (Edwards, Usher 2008; Suárez-Orosco 2004; Rocha, 2012; Mattos, 2011; Souza, 2011; Maciel, 2010, 2011; Monte Mór, 2012, entre outros) apontam que transformações de natureza econômica, tecnológica e social no século XXI, ocorridas na sociedade, têm desafiado a educação e, consequentemente, as políticas públicas educacionais para o ensino de línguas estrangeiras a desenvolver novas possibilidades no planejamento de propostas curriculares, bem como novos desenhos para a formação de professores.

Embora as línguas estrangeiras, no sistema educacional brasileiro, tenham conquistado espaço no currículo escolar com a regulamentação da LDB 9496, que instituiu a sua obrigatoriedade como disciplina no currículo, por questões de poder, de tradição e de oferta de professores nessa área, a língua 
inglesa ocupou o lugar majoritário comparado com as outras línguas estrangeiras que não detêm o mesmo destaque. Esse prestígio também se dá em função do status que ocupa como língua franca no contexto da globalização.

Observo que os documentos oficiais também contribuem para reforçar a hegemonia da língua inglesa. Identifico em um dos documentos oficiais abordado nessa pesquisa, que o ensino da língua inglesa na escola é frequentemente justificado por se tratar da língua oficial da globalização, bem como no discurso de professores, conforme ilustrado no início desta sessão. Neste capítulo, discuto alguns aspectos relacionados à interface da globalização e educação, bem como as implicações para a formação de professores de inglês a partir de discussões durante o processo colaborativo com as professoras bem como os relatos dos alunos ao serem entrevistados por este pesquisador. Busco, então, responder a seguinte pergunta de pesquisa:

0 que as discussões com as professoras revelam sobre 0 ensino da língua inglesa para uma sociedade globalizada?

O discurso de inclusão da disciplina de língua inglesa como ferramenta para conectar ou "incluir" o aluno em um mundo globalizado é bastante comum em vários outros documentos oficiais. Monte Mór (2007) critica esse argumento ao afirmar que as políticas linguísticas não devem se limitar à função instrumental de letramento. Para a autora, o ensino de língua inglesa deveria, na prática, ter um compromisso político e crítico em relação ao seu papel no currículo escolar como disciplina formadora. Nesse sentido, apresento, na sequência, os estudos sobre globalização e suas interfaces com 
a educação e o ensino de línguas. Em seguida, discuto a interface das políticas linguísticas e a formação de professores via documentos oficiais.

\subsection{Globalização e educação}

A palavra globalização ou, no francês, mundialização, representa uma das metáforas que tem sido usada pelos teóricos para abordar as transformações na sociedade. Além da globalização, vários outros conceitos como pós-fordismo, modernidade tardia, capitalismo rápido, sociedade em rede (Castells, 1999), digimodernismo (Kirby, 2009), entre outros, são empregados na literatura para descrever as mudanças sociais. No entanto, para delimitar esse estudo, optei pelo termo globalização como uma abordagem guardachuva para discutir a relação entre educação e ensino de línguas neste capitulo.

A escolha também se justifica pela percepção da relevância do tema durante o estágio de doutorado sanduíche que realizei no Centro de Globalização e Estudos Culturais no Centro de Globalização e Estudos Culturais na Universidade de Manitoba no Canadá. Meu interesse nessa temática já havia sido despertado ao cursar uma disciplina oferecida pelo departamento de Letras Modernas da USP, sobre o título de globalização e conhecimento transcultural, por ocasião da vinda da professora visitante, doutora Diana Brydon, a esse departamento. A partir dessas duas experiências, busco reinterpretar conceitos e significá-los para as políticas públicas voltadas para o ensino de línguas e para a formação de professores de língua inglesa. 
A globalização, segundo Becker (2009), é o termo dominante usado para descrever muitas mudanças, principalmente no que se refere às culturas nos últimos 100 anos. Dewey e Jenkins (2010, p. 94) situam a globalização como "uma nova ordem pós-tradicional, forjando novas identidades, instituições e maneiras de viver." Os teóricos têm apontando consenso com relação ao fluxo de capital global de pessoas e de produtos culturais (mídia, música, língua) que tem aumentado drasticamente nos últimos anos. Por outro lado, apesar do aspecto da desterritorização, a globalização também fortalece o debate em relação à preocupação com segurança, fronteira, imigração, entre outros, principalmente nos países mais afetados pelas diásporas. No contexto do ensino de línguas, a primeira versão costuma estar presente nos diálogos entre globalização e ensino de línguas segundo uma lógica de conformidade que privilegia a visão do centro sobre a periferia e justifica o ensino de inglês, segundo uma visão colonial. Essa lógica é identificada nas narrativas das professoras, conforme é apresentada no capítulo 2.

Os historiadores frequentemente se remetem à globalização como um dos maiores fenômenos sociais da humanidade e dependendo do lócus de enunciação, há divergências sobre a origem do referido fenômeno. Os estudos apontam que a globalização pode ter emergido com as grandes navegações, ou no período das colonizações e ocupações, ou nas fragmentações territoriais ocorridas na segunda metade do século XX ou pode, ainda, ter eclodido com o advento das novas tecnologias de comunicação e informação. Se considerarmos as várias perspectivas, a globalização não é um fenômeno novo. O que tem de contemporâneo, segundo, Zamanathan, Norton e Pennycook (2010, p. 1), é sua "fase, fortalecida pelos avanços na informação e 
na mídia tecnológica." O enfoque histórico não é, no entanto, a preocupação desse estudo. Portanto, limito-me a discutir apenas as questões relacionadas à presença da globalização na educação e no ensino da língua inglesa.

O fenômeno da globalização, conforme Brydon e Coleman (2008) têm contribuído para aumentar a diversidade local influenciada pelos contatos nas fronteiras culturais, bem como pelo rápido intercâmbio de produtos e informações. Essas trocas nunca são neutras e possuem profundos impactos nas esferas locais e globais. Os autores sugerem a compreensão desses processos seja a partir das lentes da autonomia, com olhares de diferentes perspectivas acadêmicas como a sociologia, a literatura comparada, os estudos culturais, a economia, entre outras.

Neste sentido, uma proposta de estudo com enfoque interdisciplinar, nas visões de Brydon e Coleman (2008), pode possibilitar diferentes olhares para as questões específicas de cada disciplina. Contudo, a interdisciplinaridade geralmente encontra dificuldades de se abordar as interrelações: a história, por exemplo, se detém nas origens da globalização; a economia no impacto econômico e social; a geografia, nas mudanças na produção e no espaço; o pós-colonialismo, nas formas políticas da cultura e do capitalismo transformacional e globalizado; os estudos linguísticos de Inglês, no papel da língua inglesa como uma força globalizante; a sociologia, na revolução da tecnologia da comunicação e informação e estruturas sociais, entre outras disciplinas.

Embora essas áreas de pesquisa tenham enfocado diferentes aspectos relacionados à globalização, tais como os citados anteriormente, uma das questões fundamentais para se falar de sociedade, ainda pouco abordada, 
é a interface da globalização com a educação e nesta, em menor proporção ainda, estão as políticas linguísticas e formação de professores, aos quais esta tese se propõe a investigar.

Sobre o aspecto educacional, Zong (2009, p. 73) afirma que "as rápidas mudanças globais desde a década de 90 têm acelerado a interdependência global na economia, na tecnologia, na política e na cultura" e, em função disso, têm possibilitado perspectivas globais para a formação de professores. Contudo, o autor questiona o propósito de se ensinar em uma perspectiva global, sobretudo com relação aos elementos de uma formação de professores com foco e escopo orientados globalmente, por silenciar os aspectos locais e reforçar modelos globais.

No entanto, pode haver aspectos de interdependência, como por exemplo, o objetivo de contemplar os conteúdos além das disciplinas, ou seja, a preocupação de contemplar "uma abordagem mais holística que ofereça ao aluno um entendimento de si mesmo e seus relacionamentos com a comunidade mundial", conforme apontado por Zong (2009, p. 74). A partir dessa perspectiva, entendo que o ensino da língua inglesa ${ }^{3}$, assim como outras disciplinas do currículo, pode contribuir para formar professores para "construir pontes entre as fronteiras culturais", ou seja, pode contribuir para 'formar' cidadãos que sejam capazes de se comunicar e colaborar com outros que tenham atitudes, valores, conhecimentos e maneiras de fazer coisas diferentes de suas próprias. Associo a essas ideias a proposta das Orientações Curriculares para o Ensino Médio - língua inglesa, principalmente no que se

\footnotetext{
${ }^{3}$ Refiro-me aqui à visão pós-colonial, ligado a grupo dos World Englishes.
} 
refere ao desenvolvimento do letramento crítico, conjuntamente com o ensino de línguas estrangeiras.

Embora haja vários estudos sobre a globalização, principalmente os que fornecem um debate sobre 0 relacionamento entre o capitalismo e a democracia, Ives (2006, p. 124) aponta que as pesquisas sobre o papel da língua nesse processo ainda é pequeno, sobretudo no que se refere à interface da "ideologia do individualismo, do seu efeito e de como a língua inglesa é compreendida." Essa questão é evidenciada nos relatos das professoras sobre os aspectos ideológicos de se aprender inglês, principalmente relacionado a uma questão individual e neoliberal.

P2: Quem tem mais acesso tem mais poder, tem mais condições de conseguir um emprego, tem mais possibilidades de avançar, de conhecer mais, de ter mais acesso a outras coisas [...] a partir do momento que você tem o conhecimento da língua mesmo.

Sensível ao contexto global, Zong (2009, p. 71) salienta que a educação possui a responsabilidade de "transformar o currículo e a pedagogia" com o propósito de 'formar' os professores para educar a jovem geração no que tange à crescente interdependência global e seu papel na sociedade global emergente, uma questão que é analisada mais adiante. A expansão do processo de globalização tem gerado novos campos de estudos, novas abordagens para a comunicação, novos letramentos, novas redes de trabalho transnacionais e novas abordagens para pesquisa.

Assim, o contexto complexo e interdisciplinar das questões que definem tanto os desafios quanto às oportunidades no mundo contemporâneo demanda que a educação global faça uma ampla reforma escolar. Como 
discuto no capítulo sobre as reformas educacionais, nas últimas duas décadas, as políticas educacionais têm sido sinônimo de mudanças. Contudo, observamos que o fato de haver várias propostas não significa que determinado documento corresponda às novas demandas educacionais.

Por outro lado, quando se tenta contemplar um currículo que considere questões globais, isso não significa que vai haver uma homogeneização de propostas. Isso se justifica porque a globalização cultural trouxe para a sociedade contemporânea, componentes multiétnicos, multiculturais e multilinguais, devido aos movimentos demográficos que Kramsch (2005, p. 15) descreve como "desterritorizados e híbridos". O argumento da autora está mais diretamente ligado aos contextos do norte global em que as escolas têm enfrentado desafios com movimentos de diásporas para os países em desenvolvimento.

No Brasil, salvo os contextos de fronteiras com países da América Latina, a globalização tem seus efeitos mais visíveis no impacto econômico que trouxe para a sociedade a formação de grandes lacunas sociais, entendidas como questões de exclusão social. No entanto, independente do espaço geográfico, a globalização possui impacto na forma em que as pessoas se relacionam, desestabiliza centros de autoridade e segurança, interfere na organização de mercado, contribui para a produção e para a difusão de formas culturais. Em função disso, Brydon e Coleman (2008) sugerem que as bases fundamentais de muitos aspectos das complexidades das condições humanas sejam repensadas.

Com relação aos enfoques de pesquisa na academia, Schole (2005) afirma que a expansão do processo de globalização ajudou a promover novos 
campos de estudos, novas abordagens para a educação, novos letramentos e novas formas de evidências científicas. O crescimento de redes transnacionais tem transformado as abordagens para a pesquisa, bem como para o ensino e para a aprendizagem. As novas possibilidades de pesquisa na globalização aumenta a agência do pesquisador, pois permite revisitar os estudos disciplinares mais restritos.

Os currículos que tomam como base o impacto da globalização, segundo Schole (Ibid.), deveriam levar em consideração alguns aspectos, como por exemplo, a cidadania global que pode oportunizar que os aprendizes se engajem como cidadãos globais ou consumidores de valores globais de justiça social ${ }^{4}$, bem como fazer uso das novas tecnologias de informação e comunicação nas novas epistemologias digitais.

Além disso, numa revisão nas tradições educacionais na construção de conhecimento, Lankshear et al (1996) questionam o papel da escola tradicional que incentiva o aluno a extrair o sentido do texto e representar o significado canônico. Nesse tipo de escola, o professor, por sua vez, representa a autoridade em termos de interpretação e precisão. Essa visão de conhecimento e sentido se contrapõe com os pressupostos das novas epistemologias. Estas indicam que o significado é mais aberto, diverso e é automonitorado; logo, não há significados que precisam ser 'desvendados'. Assim, o significado é negociável e negociado pelo usuário. O aprendiz não interpreta simplesmente os significados, mas também colabora ativamente na

\footnotetext{
${ }^{4}$ Destaco que quando se aborda o conceito de justiça social, é importante que o leitor leve em consideração as epistemologias do sul, conforme aponta Souza e Santos (2007).
} 
criação dos significados. Esse desenvolvimento pode torná-lo mais capaz de determinar suas próprias trajetórias na aprendizagem.

O ciberespaço em que a linguagem digital se constrói não afeta apenas as pedagogias em si, mas a identidade dos aprendizes, pela forma em que estes constroem o conhecimento. Contudo, Edwards e Ursher (2008) argumentam que para alguns aprendizes, devido à tradição, esses novos ambientes podem não ser interpretados como formas legitimadas de construir conhecimento. Essa questão também pode ser associada ao discurso de professores e de pais que, dependendo da concepção epistemológica que compreendem e defendem, prezam pela manutenção desta no contexto educacional.

\subsection{O papel da língua inglesa como língua da globalização}

A língua inglesa tem contribuído para a disseminação do conceito de globalização. Mais incisivamente, Omoniyi e Saxena (2010) apontam que a língua não apenas é considerada como crucial para o processo de globalização, mas é, sobretudo, o que dá vida a esse fenômeno. Por questões principalmente econômicas, Yano (2009) alega que "uma vez que a interação entre as pessoas no mundo se tornou mais próxima e mais frequente, essa interação requer que as pessoas ganhem conhecimento de uma língua em comum". O inglês, principalmente por questões de presença de poder econômico se transformou na língua mais estudada no mundo, conforme afirma Graddol (2006).

Essas questões podem ser identificadas em vários contextos das relações sociais, bem como nas relações comerciais: nas marcas dos produtos, 
na padronização das publicações científicas, na homogeneização cultural da indústria cinematográfica e da música, no ranqueamento das universidades que são pontuadas pelas publicações em língua inglesa, na expansão dos cursos livres de línguas, nos discursos hegemônicos de progresso e ascensão a um poder simbólico, entre outros aspectos. Assim, mundialmente, a língua inglesa tem conquistado um espaço no currículo das escolas.

Embora todos esses exemplos ilustrem uma questão contemporânea da presença da língua inglesa no ensino, para compreender melhor esse processo, Pennycook (2007) chama atenção para o contexto histórico, mais especificamente para a relação entre o ensino da língua inglesa e o colonialismo. O autor argumenta que essa relação ocorre em função de três fatores: o primeiro é devido à expansão do império inglês e norte americano. 0 segundo possui uma razão política e econômica, que advém do aumento do império norte americano como nova potência mundial e do enfraquecimento do império inglês. Seus reflexos podem ser identificados na expansão do ensino da língua, nos métodos de ensino, nos materiais didáticos com questões ideológicas de relações coloniais ou neocoloniais e da língua inglesa numa visão imperialista. O último aspecto refere-se às questões culturais que reforçaram as práticas e as crenças do colonialismo que reproduzem imagens do idioma inglês como língua e cultura superiores, conforme pode ser identificado no excerto a seguir:

P: Vamos discutir então o documento [...] sobre o status do inglês como língua global [...]

P2: Sim, ele coloca que a língua estrangeira também ajuda o aluno a ter conhecimento da língua dominante [...] 
P: E o que você acha dessa língua dominante? Qual é o status que o documento coloca em relação ao inglês? Quando afirma que temos uma língua dominante, que implicação isso tem?

P2: Quem tem mais acesso tem mais poder, tem mais condições de conseguir um emprego, tem mais possibilidades de avançar mais, de ter mais acesso a outras coisas a partir do momento que você tem o conhecimento da língua mesmo. Então, por exemplo, ele diz o seguinte, que os subalternos, a maneira que eles tem que servir [...]

$P:$ Quem são os subalternos?

P3: São pessoas mais humildes, são as pessoas que não têm condições financeiras para se desenvolver em um país capitalista. Então ele diz o seguinte, uma das ferramentas dos subalternos terem acesso, crescerem, mudam a sua própria vida é ter conhecimento de outra língua, que é a língua estrangeira, que é o inglês, que ele considera a língua dominante.

$P$ : O que você acha disso P2?

P2: Eu não acho que é por esse caminho. Eu acho que é para o conhecimento pessoal do aluno, para o conhecimento de novas culturas, como uma forma de comunicação com outras pessoas, não como o objetivo de ensinar uma língua dominante, não é por aí não. Para formar cidadãos mais críticos [...] que podem participar de todo tipo de discurso [...] a nível de mundo [...]

O discurso da professora 2 aproxima-se mais da acepção língua de acesso e participação na sociedade, conforme visão de Graddol (2006). Para o autor, a língua inglesa é discursivamente legitimada como uma das habilidades essenciais na formação para a sociedade de hoje, juntamente como a habilidade de uso das novas tecnologias da informação. Nesse contexto, o ensino da língua inglesa privilegia o modelo dos "falantes nativos", como o ideal a ser alcançado. Dewey e Jenkins (2010), dentro do contexto dos world 
Englishes, apontam que a língua inglesa está inserida em uma interação mais complexa e multifacetada do localismo e do globalismo e que vai muito além do que uma simples habilidade de inserção em um mundo globalizado. Para eles, a força desse idioma está relacionada à maneira pela qual o local é remoldado e renegociado sob pressões de diferentes contextos globais. Na interação com as professoras, a língua inglesa ligada ao inglês mundial está mais voltada como um capital intelectual do que variedades linguísticas que são moldadas ou remoldadas em função do local, conforme a discussão a seguir.

P: Então aprender essa língua dominante [...] que isso vai levar a um aprofundamento intelectual, será que aprender língua inglesa garante um aprofundamento intelectual? Será que os que não falam língua estrangeira estão em uma posição inferior aos que conhecem?

P2: Olha, em um plano inferior não está, mas acredito que quem tem conhecimento de língua inglesa tem um conhecimento muito maior, ele vai ter um relacionamento maior, ele vai ter sim um aprofundamento maior.

$P:$ Mas será que quem tem conhecimento só da língua materna é menos intelectual do que tem o conhecimento de outra língua?

P2: Mas só que é tradução [...] que quando você conhece, você faz a leitura e tem a sua interpretação, então quando a gente lê a tradução de um determinado assunto, de uma determinada informação interpretada por outra pessoa [...] eu acredito que quem aquele que domina outra língua tem uma superioridade [...] pode não ser tão grande.

Pesquisadores como Seidlhofer (2009), Jenkins (2003), Widdowson (2010), Pennnycook (2007), Canagarajah (2005) afirmam que o aumento internacional do uso do Inglês requer que a presença desse idioma seja 
considerada para além do contexto do falante nativo. Desse raciocínio, emerge a percepção de que a língua inglesa não pertence apenas aos falantes dos países em que esse idioma é a língua materna. Sobre esse aspecto, apresento um excerto em que essa questão emergiu na discussão dos dois documentos oficiais:

P: Como a gente tinha falado hoje de manhã, discutindo o documento do estado, onde aparecia: "O inglês está conectando o mundo", falava do inglês como língua global ai eu fiz uma pergunta pra vocês: se o inglês é uma língua global, de quem é essa língua? De ninguém? É de todos? E falar em cultura, se esse inglês representa todos, por que a gente vai trabalhar com a cultura do americano ou do britânico? se é global. E o que os alunos acham disso? E o que vocês acham disso? [retomando a discussão do encontro anterior]

P1: Eles acham que é a cultura americana.

P2: Eu pensava assim e fui mudando, porque eu fiquei um ano fora, depois eu tive a oportunidade de retornar e fui vendo que o inglês é um meio de comunicação, então não é meu, não é seu, é de todos. Por que qual o objetivo de se aprender inglês? É você ter um inglês perfeito ou para usar para chegar em alguma coisa? Percebi que a concepção está mudando, várias formas de falar uma mesma coisa, justamente aquilo que você falou no começo, algo global. Mas os alunos carregam isso com eles, porque eles não tiveram a oportunidade de conversar com alguém ou precisar do inglês como fonte para alguma coisa.

O relato da professora 2 possui uma identificação com o círculo em expansão de Kachru. Sobre esse aspecto a quem pertence o inglês e suas questões ideológicas, o autor apresentou um modelo para divisão dos falantes 
da língua Inglesa em três círculos: o círculo interno, o círculo externo e o círculo em expansão, conforme ilustrado pela figura a seguir:

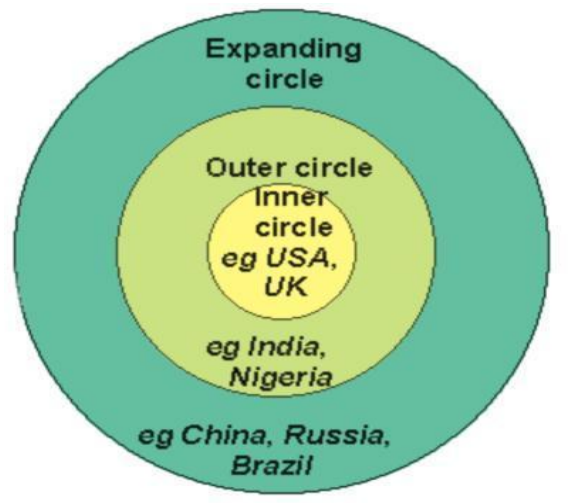

Figura 1: Os três círculos propostos por Kachru (1984)

O primeiro deles - o circulo interno - refere-se à tradição monolíngue, de maioria branca, que representa a primeira onda de diáspora das ilhas britânicas. Esses são considerados como fornecedores de regras normativas, tais como modelo adequado ou correto a ser ensinado e aprendido, conforme apontam Park e Wee (2009).

O segundo - o circulo externo - contempla a segunda onda de diáspora e está relacionado à história do colonialismo de países falantes de língua inglesa, nos quais a língua inglesa possui o status de língua oficial. Assim, pode ser considerada a língua materna ${ }^{5}$, mas sofre influência do contato com línguas locais. O contato com outras línguas proporcionou o surgimento dos novos tipos de língua inglesa que são distintos do círculo interno.

O último dos três - o círculo em expansão - não possui status oficial e serve principalmente como ferramenta de comunicação internacional. Nele, identificam-se características vistas também como formas de imperialismo

\footnotetext{
${ }^{5}$ Menezes de Souza (2012) afirma que o conceito de língua materna é problemático uma vez que pressupõe homogeneização.
} 
cultural. São exonormativas e dependem da norma tradicional. Caracterizamse pelo desejo da aprendizagem da língua inglesa com base no padrão do círculo interno.

Embora seja bastante influenciado pelos estudos pós-coloniais, esse modelo tem recebido críticas. Park e Wee (2009, p. 390), por exemplo, afirmam que essa nomenclatura não obteve sucesso para promover a consciência dos reais contextos. Além disso, essa relação é bastante orientada no que tange à ideia de estado-nação, como se os vários países pudessem ser divididos em três categorias. Assim, há uma correlação entre as questões históricas e o status sociolinguístico do inglês em um dado país. Com isso, perpetuam-se as desigualdades e as dicotomias que tanto se objetivou a combater, tais como a noção de falante nativo e não nativo. Além disso, essa visão contraria a noção de heterogeneidade, apontada por Pennycook (2007). Segundo o autor, a heterogeneidade tende a aumentar como reflexo da globalização, uma vez que um efeito chave é o aumento do fluxo de objetos, incluindo, conforme Appadurai (2000, p. 05) "as ideologias, as pessoas e os produtos, as imagens e as mensagens, as tecnologias e as técnicas". Considera-se, então, que a língua não está isenta dessas questões.

Este modelo, segundo Seidlhofer (2010, p.35), é incapaz de "informar ou explicar o volume da comunicação", entre o número cada vez mais crescente de falantes não nativos no mundo hoje. Além disso, Pennycook (2010) também questiona a relevância de tal modelo para representar as variedades no contexto da globalização onde as identidades não são préestabelecidas ou necessariamente ligadas a políticas nacionalistas. Neste sentido, apesar da tentativa de Kachru de buscar legitimar outras variedades 
de inglês, o modelo proposto deixou de lado muitas formas híbridas de inglês local.

Por outro lado, Kachru trouxe para academia um olhar para as diferentes variedades da língua inglesa no mundo. Apresentou, ainda, um vocabulário conceitual para abordar as questões complexas da relação entre a estrutura linguística e sua ampla economia política.

Apesar de seu prestígio como língua internacional, em termos educacionais, a língua inglesa ainda possui fortes ideologias relacionadas à variante padrão dos falantes nativos como modelo a ser ensinado. Essa concepção pode ter consequências ideológicas, tanto para o professor, quanto para o aluno. O professor pode ocupar uma posição hierarquicamente inferior ao nativo em termos de sotaque e especialidade. $\mathrm{O}$ aluno, por sua vez, pode assumir o papel daquele que está em busca de alcançar a variante do falante nativo, sobretudo do aspecto anglo-americano. Mesmo que o enfoque fosse as variantes do círculo interno, a partir de uma visão que considera o aprendiz como colonizado, seria ingênuo pensar que se possa garantir um modelo, devido às várias variantes que cada contexto possui.

Pakir (2009) apresenta uma tabela para descrever as implicações do inglês, apropriando-se de duas visões propostas por Pennycook descritas nas colunas um e dois (2002) e acrescenta uma terceira sobre as implicações pedagógicas que o Inglês do círculo interno, Inglês como Língua Internacional e BANA (British, Australian, North American) possuem como visões, conforme exemplificado abaixo.

\begin{tabular}{|l|l|l|}
\hline Visão da expansão global do & $\begin{array}{l}\text { Implicações para cultura e } \\
\text { Inglês }\end{array}$ & Implicações Pedagógicas \\
\hline
\end{tabular}




\begin{tabular}{|l|l|l|}
\hline Celebração colonial & $\begin{array}{l}\text { Inglês: uma língua herdada } \\
\text { útil }\end{array}$ & $\begin{array}{l}\text { Ensinar Inglês para aqueles } \\
\text { que podem apreciá-lo }\end{array}$ \\
\hline Modernização & $\begin{array}{l}\text { Inglês: uma ferramenta } \\
\text { crucial para a modernização }\end{array}$ & $\begin{array}{l}\text { Ensinar Inglês para } \\
\text { modernizar o mundo }\end{array}$ \\
\hline Liberalismo Laissez-faire & $\begin{array}{l}\text { Inglês: uma ferramenta } \\
\text { funcional para propósitos } \\
\text { pragmáticos }\end{array}$ & $\begin{array}{l}\text { Ensinar Inglês é um negócio: } \\
\text { dar as pessoas o que elas } \\
\text { querem }\end{array}$ \\
\hline
\end{tabular}

Tabela 1: ICE, IE and BANA points of view (In: Pakir 2009, p.226)

As três visões do inglês internacional (colonial, modernização e liberalismo) implicam uma "ferramenta comunicativa de poder" na qual subjaz uma das ideologias da globalização. Nela, o idioma inglês se transformou em um produto legitimado que incentiva a proficiência linguística segundo 0 modelo do círculo interno. Em termos pedagógicos, o quadro a seguir apresenta outras questões relacionadas ao inglês internacional.

\begin{tabular}{|l|l|l|l|}
\hline Abordagem & Expoentes & Objetivos & Pesquisa e Prática \\
\hline (ELT/EFL) & Prator/Quirk & Ensinar variedades & Currículos, \\
Foco: proficiência linguística & & estabelecidas do & metodologias, materiais \\
Defensores: TESOL, & & Inglês (Padrão & e avaliação com base \\
IATEFL & & Inglês ou Padrão & em BANA \\
& & Americano) & \\
\hline
\end{tabular}

Tabela 2: The IE paradigmatic axioms (In: Pakir 2009, p.228)

O modelo internacional está sendo questionado no século XXI por paradigmas emergentes como World English e English as a Lingua Franca. A principal crítica se refere à preocupação em garantir a proficiência linguística, segundo o modelo do círculo interno. Neste sentido, busca-se reduzir as "deficiências" do aprendiz e justifica-se com a diminuição do sotaque pelos argumentos das teorias linguísticas de aquisição como a interlíngua e 
fossilização, que foram bastante difundidas nas décadas de 80 e 90 . Além disso, destaca-se a visão monocultural percebida no ensino de inglês como língua estrangeira que beneficia principalmente a variante inglesa ou norte americana. Além do conceito do Inglês internacional, os termos inglês mundial e inglês como língua franca são outros aspectos discutidos por Pakir (2009) para foco de pesquisa e práticas pedagógicas.

Dos três círculos apontados por Kachru, o Inglês Mundial (World English) está mais relacionado ao círculo em expansão. Segundo Botton (2004), o termo funciona como um rótulo guarda-chuva de todas as variedades da língua inglesa, defendida pela expressão 'new Englishes'. Pakir (2009) esclarece que no âmbito da linguística aplicada, o termo world Englishes refere-se particularmente a uma ampla abordagem para o estudo da língua Inglesa no mundo. Os estudos nessa perspectiva são particularmente associados aos trabalhos de Kachru e outros teóricos que utilizam o paradigma world Englishes, conforme resumido no quadro a seguir.

\begin{tabular}{|c|c|c|c|}
\hline Abordagem & Expoentes & Objetivos & Pesquisa e Prática \\
\hline $\begin{array}{l}\text { (ELT/ESL/EFL) } \\
\text { Foco: realidades } \\
\text { sociolinguísticas } \\
\text { Defensores: } \\
\text { IAWE, College of } \\
\text { World Englishes }\end{array}$ & $\begin{array}{ll}\text { Kachru (1982, } & 1983, \\
1986, \quad 1996) ; & \text { Smith } \\
(1981, & 1988) ; \\
\text { Lowenberg } & (1984) ; \\
\text { Pakir (1994, 1997); } & \text { (1984) } \\
\text { Bautista (1997) }\end{array}$ & \begin{tabular}{|lr} 
Promover & a \\
pluralidade do Inglês e \\
a & 'criatividade \\
bilíngue' & do circulo \\
externo: & valorização \\
do & conhecimento \\
bilíngue &
\end{tabular} & 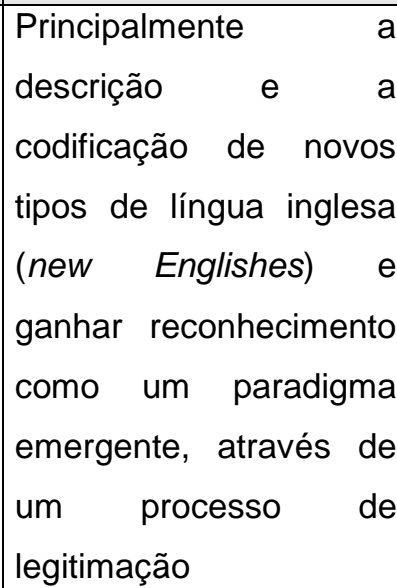 \\
\hline
\end{tabular}

Tabela 3: The WE paradigmatic Axioms (In: Pakir 2009, p.228)

Diferentemente do Inglês como língua internacional, portanto, o inglês mundial preocupa-se com outros aspectos que não sejam meramente 
linguísticos: consideram-se, então, as realidades sociolinguísticas, as questões ideológicas que subjazem à aprendizagem da língua inglesa, bem como às dimensões culturais de seus usuários.

O último termo, Inglês como língua franca, influenciado por pesquisadores pós-colonialistas, é definido como uma língua de contato entre pessoas que não compartilham de uma mesma língua materna, nem de uma mesma cultura nacional. Neste caso, a língua inglesa é utilizada como língua estrangeira de comunicação, conforme apontado Seidlholfer (2004). Similarmente, Jenkins (2009) define língua franca como uma língua de escolha em comum entre os falantes de diferentes contextos de língua e cultura. Neste sentido, a autora aponta que World English (WE) e English as a Lingua Franca (ELF) possuem têm grandes identificações.

No entanto, esse argumento, segundo Modiono (2009), excluiria os falantes nativos e, portanto, a noção do idioma Inglês como lingua franca deveria ser revisada. O autor então sugere que "uma língua franca é uma língua que tem uma considerável utilidade em contextos multiculturais, entre pessoas com diferentes perfis" (ibid, p. 212). Se considerarmos essa perspectiva, a noção de inclusão promove uma adaptação entre os três círculos. Apesar da tentativa de se ampliar a discussão de Kachru que então possui três círculos bem definidos, o termo língua franca implica uma forma de homogeneização. Esse argumento, segundo Pennycook (2010), perde a crítica de que "precisamos reagir não apenas às novas condições da pósmodernidade, mas também ao imperativo pós-moderno de repensar a língua" (ibid., p. 196). Isso sugere a necessidade de articular um novo sentido de história e localização, evitando-se as narrativas de expansão, transição, 
desenvolvimento e origem, e partir disso, considerar a multiplicidade, a heterogeneidade e as simultaneidades históricas que a narrativa dominante tenta cristalizar. Pakir (2009), a seguir, exemplifica as implicações do termo lingua franca.

\begin{tabular}{|c|c|c|c|}
\hline Abordagem & Expoentes & Objetivos & Pesquisa e Prática \\
\hline $\begin{array}{l}\text { (ELT/EFL) } \\
\text { Foco: } \\
\text { conectividade e } \\
\text { comunicação } \\
\text { menos o aspecto } \\
\text { língua cultural do } \\
\text { Inglês } \\
\text { Internacional } \\
\text { Defensores: } \\
\text { IAWE, College of } \\
\text { World Englishes }\end{array}$ & $\begin{array}{ll}\text { House } & (1999) ; \\
\text { Seidholfer } & (2001 ; \\
2004 ; 2006) ; & \text { Jenkins } \\
(2000 ; 2004 ; 2006)\end{array}$ & 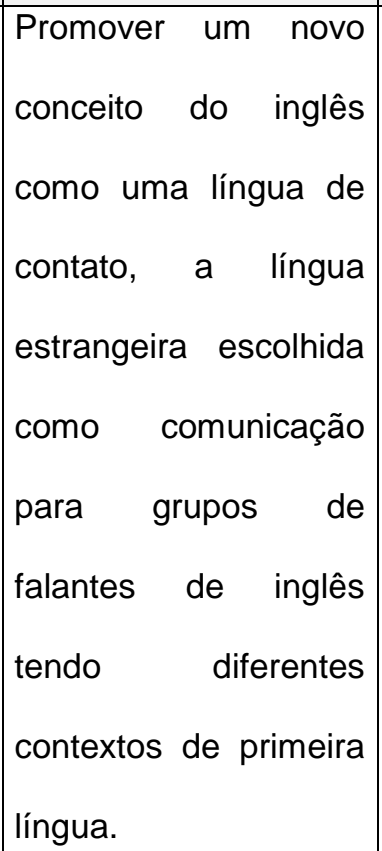 & $\begin{array}{l}\text { Definições e contexto de } \\
\text { parâmetro; } \\
\text { Descrição e codificação; } \\
\text { Fonologia; } \\
\text { Léxico-gramática; } \\
\text { Características distintas } \\
\text { de ELF; } \\
\text { Supra-características. } \\
\text { Ex. A pragmática. }\end{array}$ \\
\hline
\end{tabular}

Tabela 4: The ELF paradigmatic axioms (In: Pakir 2009, p.229)

A partir da perspectiva apontada por Parkir (2009), tanto o inglês mundial quanto a língua franca possuem quatro características principais: enfatizar a pluralidade do inglês; buscar um reconhecimento de variedade; aceitar que a língua muda e se adapta a novos contextos e enfatizar as estratégias discursivas do conhecimento bilíngue do inglês.

Essas premissas estão relacionadas ao efeito da globalização e ao status da língua inglesa nos quais os vários falantes buscam posse ${ }^{6}$ em relação à língua. Embora cada termo tente acomodar os falantes em categorias, o nome mais distinto é o inglês internacional, pois este delimita

\footnotetext{
${ }^{6}$ Em Inglês ownership.
} 
mais claramente a quem a língua pertence (círculo interno). Já o inglês mundial e o inglês como língua franca, apesar das similaridades apontadas, também podem ser diferenciados em alguns aspectos. $O$ inglês mundial inclui todos os usuários dos três círculos e o inglês como língua franca, por outro lado, opta pelo círculo em expansão que não possui as mesmas características que os círculos interno e externo.

No contexto da globalização, adotar o Inglês Internacional seria legitimá-lo como poder simbólico. No entanto, adotar o paradigma do inglês mundial (World Englishes), que considera o hibridismo linguístico e a atuação pós-colonial, parece estar em conformidade com o círculo externo ou em expansão. Os pesquisadores, influenciados pela visão Kachruana de pluralidade de Inglês em três esferas de usuários, apontam as limitações do círculo interno em termos metodológicos a começar pelas nomenclaturas English as a Second Language (ESL) e English as a Foreign Language (EFL), pois implica a uma relação de posse atribuída à língua.

Retomo a discussão com as professoras que, no relato anterior, reportaram que os alunos entendiam que a língua inglesa estaria relacionada a dois falantes: os americanos e os britânicos. No entanto, com o passar do tempo e do enfoque das professoras com menos ênfase às questões estruturais, e com mais enfoque em temas comparativos e críticos, as visões dos alunos parecem mudar em relação ao status do inglês. A seguir, destaco um relato da professora 2 sobre a sua percepção em relação às diferenças em suas aulas:

P: E quando você começa a trabalhar com temas agora, que você me mostrou há pouco, como você acha que os alunos se sentem em relação à língua inglesa? 
P2: Eles têm um porquê, eles estão vendo que é um meio, acho que eles deixam até de lado a questão de ser americano ou britânico, eles estão vendo que eles podem falar com o mundo usando essa língua, o inglês. Até a questão do erro é vista de forma diferente, veem uma oportunidade de tentar aprender e que o erro é bem vindo também.

Para finalizar a discussão dos três termos, pode-se dizer que eles se referem a diferentes perspectivas. O primeiro, inglês internacional, enfatiza a ideologia padrão, ou seja, torna o falante nativo como ponto de partida. Esse conceito tem sido criticado por pesquisadores como Phillipson (1992), Pennycook (2002), entre outros, pois representa à longa "glorificação" da língua inglesa.

O segundo, inglês mundial, enfatiza a importância das realidades sociolinguísticas, ou seja, considera que a língua muda e se adapta. Essa pluralidade mostra formas híbridas dos "new Englishes", com múltiplas vozes pela liberação linguística, defendida por Kachru.

O último, Inglês como língua franca, limita-se ao círculo em expansão que não possui semelhanças de usuários que utilizam o idioma inglês como língua de comunicação. Este modelo, conforme Pennycook (2010) negligencia o caráter inclusivo e plural do fenômeno mundial do inglês. O autor ainda aponta que a academia precisa ir além da simples questão de pluralização (English versus Englishes), uma vez que deixa de lado os aspectos relacionados à escala e epistemologia e enfatiza a ideia da conectividade associada à língua inglesa.

No que se refere à relação entre língua e cultura em termos de 'fluxo' e 'contra fluxo', observa-se uma tensão entre o global e o local. Essa 
tensão, segundo Graddol (1997), produz o surgimento do inglês global, ou seja, é internacionalmente orientado, mas localmente situado conforme apontado por Pakir (2009). Nessa visão, o idioma inglês local e inglês global podem ser vistos tanto como internacional ou língua franca.

A dicotomização global-local, centro-periferia também é discutida pelo sociolinguísta Blommaert (2010), referindo-se, especificamente, ao contexto da linguagem. Ao invés de global e local, ele sugere o termo translocal, por não remeter a uma noção geral como é o caso da palavra glocalização que, por sua vez, sugere a interferência do global sobre o local. 0 autor (Ibid, p. 79) vê "a localidade transportada na localidade" e que as localidades necessariamente não se tornam mais globais ou desterritorizadas, por causa dos padrões de translocalização". Além disso, ele também demonstra o seu desconforto com a visão de globalização na qual o local é apenas usado como algo estável e tradicional, bem como as visões pelas quais a localidade é vista como efeito da desterritorização.

Esses argumentos limitam a globalização como algo de natureza primariamente relacionada à diáspora, ao invés de formas de mobilidades semióticas. Elas podem ser identificadas, conforme Blommaert (2010, p. 79), "nas formas, nas imagens, nos discursos e nos padrões de conduta que se tornam relocalizadas nos padrões existentes". Em outras palavras, elas permanecem localizadas em suas estruturas, mas sofrem mudanças graduais, e, dessa forma, o velho coexiste com o novo, tornando-se, então, relocalizado.

O processo de mistura do velho com o novo se torna um veículo de inovação cultural. Assim, Blommaert (2010, p. 80) afirma que "as línguas e os discursos se movem pelos entre espaços cheios de regras, normas, hábitos e 
convenções, adaptando-se, então, às regras, às normas, aos hábitos e às convenções de tais localidades antes de se mover em suas trajetórias". Com isso, o autor sugere um novo olhar para a sociolinguística, uma vez que a globalização força a referida área a repensar a sua visão clássica e reconsiderá-la como uma sociolinguística de recursos móveis. Neste sentido, com a translocalização, a pesquisa não se detém apenas aos modelos tradicionais que levavam em consideração os repertórios dos falantes da língua, dispostos de forma fixa no tempo e no espaço, conforme apontado por Kachru. Como alternativa, o autor propõe, então, a sociolinguística da mobilidade. Esta possibilidade também se estende ao estudo da língua inglesa como algo não fixo e homogêneo, ou seja, algo integrante desse fluxo da globalização ou translocalização.

Além dos três círculos de Kachru e da sociolinguística da mobilidade de Blommaert $(2003,2010)$ discutidos neste trabalho, dois outros enfoques também mostram possibilidades de se abordar as variedades da língua inglesa: as três grandes ondas de diásporas relacionadas à expansão língua inglesa e o conceito de worldliness.

As três grandes ondas de diásporas relacionadas à língua inglesa e suas relações com a sociolinguística da colonização e globalização são discutidas por Omoniyi e Saxena (2010). A primeira delas refere-se aos falantes da diáspora neolocal que se relocalizaram como falantes de inglês como nação (Canadá, Nova Zelândia, Austrália). Nesses locais, o inglês é a língua oficial e, com isso, marginaliza as outras línguas locais mesmo que elas sejam consideradas primeira língua. A segunda representa as ex-colônias inglesas (Nigéria, Índia, Hong Kong) e as ex-colônias dos Estados Unidos 
(Filipinas, Guam e Porto Rico). Nesses locais, o inglês ocupa espaço nas políticas linguísticas e, no caso das Filipinas possui o status de língua oficial. A terceira onda representa uma subcultura, devido às forças econômicas e políticas (China, Brasil, Japão).

A partir das três ondas de diásporas, Omoniyi e Saxena (2010) desconstroem a categoria de circulo interno e externo. Para os autores (ibid, p. 5), "o conceito de círculo externo é uma construção sociolinguística específica ao território" e, desta maneira, não consegue capturar as migrações e fluxos transculturais facilitados pelas novas mídias. Esse argumento também se aplica à categoria do círculo interno, no qual novas variantes da língua inglesa circulam nos contextos multilíngues. Esta constatação não foi contemplada em nenhum dos três círculos proposto por Kachru, uma vez que não levam em consideração a hibridação, a assimilação, a integração ou outra forma de socialização característica da globalização.

Assim, a língua inglesa não estaria diretamente ligada à história da colonização, mas estaria, no entanto, associada aos novos centros da economia global. Paradoxalmente, os países tidos como emergentes são os que mais sofrem influências da variante do circulo interno ou da primeira onda de diáspora em relação às atitudes ou às preferências. Este fato, segundo Omoniyi e Saxena (2010), reforça a ideologia de que o sotaque britânico ou americano estaria relacionado a uma hierarquia superior.

A outra proposição para o estudo da língua inglesa apontada por Pennycook (2010) é o conceito de worldliness. O autor se fundamenta no argumento de que a globalização e a língua inglesa precisam ser consideradas fora da moldura nacionalista - com seus modelos fixos de cultura, identidade, 
espaço e língua - que fundamentou os modelos do século XX. Assim, citando Hardt e Negri (2000), Pennycook (2010) se remete a uma nova forma de pensar, com base em uma mudança de perspectiva: enquanto o imperialismo representava a expansão do território, a globalização, por outro lado, representa a descentralização e desterritorização.

Nessa ótica, Pennycook (2010) aponta que worldliness oferece outras lentes para compreender os vários aspectos relacionados à língua, ou seja, worldliness representa uma crise intelectual, cultural e política do projeto euro-americano de modernidade e de direito linguístico. Para tanto, o autor (ibid, p. 2010, p. 201) aponta que quatro objetivos principais devem ser levados em consideração ao se adotar a perspectiva de worldliness:

levantar informações importantes sobre como o poder opera na relação com o estado-nação e, em particular, como a governança é alcançada pela língua; repensar a ontologia da língua como um constructo colonial/modernista; questionar narrativas ou epistemologias imperialistas, direitos linguísticos, língua franca ou world Englishes; apontar para formas locais, situadas, contextuais e contingentes de compreensão sobre línguas e políticas linguísticas.

Essas considerações produzem, portanto, um questionamento filosófico local, situado, essencialista e anti-fundamentalista para as narrativas canônicas. Associo essa relocalização dos temas ao conceito de conhecimento local apresentado por Canagarajah (2006, 2009) e Norton (2010), conforme discuto no capitulo 2. Além disso, na educação, os estudos dos novos letramentos, descritos por Cope e Kalantzis (2000) também apresentam a preocupação com as práticas de trabalho pós-fordista, como nos novos tempos, com as hierarquias horizontais, com as novas tecnologias e mídias 
que impactam nas formas de letramentos. Nas políticas educacionais, essas questões foram contempladas nas Orientações curriculares para o ensino médio, a ser expandido mais adiante.

\subsection{A língua Inglesa em uma sociedade globalizada e implicações para as políticas linguísticas}

A língua inglesa desempenha um papel importante na sociedade globalizada. Dependendo da posição de ensino assumida, esta pode ter uma função neocolonialista ou explorar uma perspectiva mais crítica. Nessa segunda visão, os estudos pós-coloniais consideram o contexto global, mas propõem um olhar sobre as comunidades locais. Eles questionam o padrão do círculo interno e sugerem que as variedades localizadas de língua e cultura sejam consideradas na educação formal.

As teorias pós-coloniais retomam o conceito de que a língua inglesa pertence a todos e ao mesmo tempo a ninguém, conforme apontado por Rajagopalan (2007) que defende a resistência ao imperialismo cultural emanado do ocidente em posição de poder. Nessa perspectiva, os teóricos pós-colonialistas buscam promover uma mudança do ensino de monoculturação para a multiplicidade linguística e cultural. Em outras palavras, o pertencimento da língua franca é um pré-requisito para a autodeterminação.

Dado o impacto da globalização, alguns autores apontam que os objetivos do ensino da língua inglesa no currículo precisam ser reconsiderados como língua franca em uma perspectiva pós-colonial, associada com bem público apontado conforme defendido por Jordão (2009) e com a democracia global, discutido por Kurosawa (2009). No entanto, as propostas curriculares 
voltadas para o ensino da língua inglesa, ao longo dos anos, têm dado destaque ao processo cognitivo, dissociado do contexto social e local.

Sobre as propostas curriculares e as implicações para a prática dos professores, Gimenez (2006) aponta que há dois mundos paralelos: o mundo dos documentos oficiais e o mundo real da sala de aula. Segundo a autora, as diretrizes parecem não ter nenhum impacto real. Isso em parte se justifica pela forma como as políticas educacionais são apresentadas. Em geral, são propostas como políticas simbólicas, que de acordo com Rizvi e Lingard (2010), não são acompanhadas do devido investimento na implementação e na formação continuada. No entanto, esses reflexos dependem de como são apresentados.

Para que o documento possa fazer sentido para o professor, Monte Mór (2007) afirma que as propostas curriculares não deveriam ser vistas pelos professores como um aspecto formal de documento. A autora propõe, para tal, que sejam reinterpretados localmente. Outro aspecto é levantado por Gimenez (2008) com relação ao uso dos documentos na formação inicial. Segundo a autora (ibid, p. 32), os "formadores de professores não estão necessariamente conscientes desses documentos ou raramente os levam em consideração no planejamento e implementação das aulas".

No que se refere ao papel educacional da língua inglesa, Fabrício e Santos (2010, p. 95) apontam que "muitos professores têm ensinado a língua sem a consciência de seus papéis educacionais e políticos na expansão das questões de valores e poderes representados pela língua, como se os domínios socioculturais e políticos fossem alheios a eles." Esse fato também pode ser usado como justificativa para que as escolas, tanto as públicas quanto 
as privadas, deem prioridade à visão instrumental da língua e, assim, não abram possibilidades para aspectos críticos globais ou locais.

As transformações causadas pela globalização, segundo SuárezOrozco e Qin-Hilliard (2004, p. 02), “requererá que os jovens desenvolvam novas habilidades que estão muito além do que a maioria dos sistemas educacionais pode oferecer". Para esses estudiosos, os alunos necessitam desenvolver visões mais amplas para estarem informados, engajados e críticos para o novo milênio, com novas habilidades cognitivas, sensibilidades interpessoais, engajados tanto com o contexto local como transnacional. 


\title{
CAPÍTULO II
}

\section{DOCUMENTOS CURRICULARES: ORIENTADORES OU DESORIENTADORES DA PRÁTICA DO PROFESSOR DE LÍNGUA INGLESA? ${ }^{7}$}

\begin{abstract}
P1: Nós tínhamos conhecimento só do referencial curricular da rede estadual, das orientações curriculares do MEC, não. Então era óbvio que nós seguiríamos o referencial curricular estadual, mas após o conhecimento das OCEM nossa prática mudou.
\end{abstract}

P2: Porque a gente não tinha uma orientação, eu acho que a realidade do professor brasileiro é chegar à escola, pegar as aulas e já entrar naquela rotina e deixar de lado documentos, teorias.

P1: Confunde bastante, como eu falei, a gente chega a trabalhar com a prática no nosso dia a dia, e quando a gente se depara com esses documentos a gente tem vários conflitos, não condizem com a nossa realidade.

A sociedade atual é caracterizada por um período de rápidas mudanças em diferentes contextos. As transformações têm redefinido novas formas de relacionamento, de trabalho e da vida social, conforme apontam Kalantízis e Cope (2005). Em função disso, vários setores da sociedade, incluindo a educação, têm buscado ainda que, em alguns contextos apenas no

\footnotetext{
${ }^{7}$ Ao ler o título desse capítulo, o leitor talvez possa esperar uma resposta fechada para tal questionamento. Ressalto, no entanto, que não é meu propósito estabelecer uma visão binária sobre a temática em questão, apenas busco problematizar para a relação entre o lançamento de diretrizes e a prática do professor.
} 
papel, redefinir suas práticas em relação às diferentes formas de aprender, de ensinar, de trabalhar e de se relacionar.

Sensível a essas questões, algumas iniciativas foram propostas pelo Ministério da Educação, por intermédio da secretaria de educação básica, buscando redesenhar o currículo escolar ${ }^{8}$ ao lançar documentos importantes para as escolas, como por exemplo, os dois vigentes para os ensinos fundamental e médio: os Parâmetros Curriculares Nacionais de 1998 e as Orientações Curriculares Nacionais de 2006, respectivamente. Além desses, diversos outros foram lançados nas esferas estaduais. Para ilustrar, tomo como base, de forma aleatória, alguns estados brasileiros durante o período de uma década que corresponde de 2002 a 2012: Paraná (2008; 2012), São Paulo (2007), Espírito Santo (2011), Minas Gerais (2008). Desses estados, o de Mato Grosso do Sul foi o que mais lançou diretrizes curriculares.

Desses estados, o de Mato Grosso do Sul foi o que mais lançou diretrizes Curriculares. Somente para o Ensino Médio foram três documentos propostos em 2004, 2008 e 2012. Desses três, nenhum possui uma interface com as propostas do Ministério da Educação (PCNEM,1999; PCNEM+, 2001; OCEM, 2006) ou ainda com o Plano Nacional do Livro Didático (2009, 2010).

Apesar de tantos documentos, ao acompanhar o trabalho de professores via estágio supervisionado no curso de letras, bem como por meio de cursos de formação continuada ou ainda pelas discussões em congressos

\footnotetext{
${ }^{8}$ Embora eu tenha brevemente mencionado algumas mudanças apontadas por Cope e Kalantízis, apenas as Orientações Curriculares para o Ensino Médio - OCEM-LE 2006 mencionam tais preocupações. Esse documento amplia a visão de linguagem proposta nos PCN-LE, 1998, conforme discuto com mais detalhes mais adiante neste trabalho.
} 
nacionais, percebo que as diferentes proposições ainda estão bem longe de serem implementadas como sugeriram os autores dos vários documentos.

Neste sentido, Gimenez (2009, p.43) afirma que há dois mundos paralelos: o dos documentos oficiais e o da sala de aula. Para a autora, as diretrizes têm sido insatisfatórias uma vez que "não tratam diretamente das questões prementes para professores e alunos, questões essas geralmente vinculadas às condições de ensino/aprendizagem nas escolas (classes numerosas, recursos escassos, tempo, etc.)". Além disso, verifiquei em uma pesquisa cujo foco foi investigar como os professores reagiam a um processo de inovação curricular (Maciel, 2001) que apenas o lançamento de documentos não garante sua aplicação na sala de aula. Para que as propostas pudessem ser implementadas, os professores relataram que outras ações, seguidas ao lançamento, poderiam ser importantes, como por exemplo, investimento em formação continuada, em infraestrutura, materiais didáticos, colaboração de profissionais da área, entre outras. No entanto, mesmo que todas essas questões fossem atendidas por parte das secretarias de educação, toda proposta pode ser passível de resistência ou de rejeição como aponta Canagarajah (2005). Para o autor, as pesquisas sobre políticas linguísticas fundamentadas no modelo neoclássico e no modelo crítico subestimam a agência humana no processo de elaboração e implementação das políticas, conforme discuto mais adiante neste capítulo.

Embora esse assunto possa ter implicações para a prática do professor, os estudos em formação de professores que levam em consideração a complexidade da relação entre as políticas educacionais e a prática de sala de aula, mais especificamente, como elas são "negociadas e (re)construídas no 
processo de implementação", segundo Menken e Garcia (2010, p.1), é ainda pouco explorada na área da formação de professores de línguas estrangeiras.

Após essa breve consideração, tomo como base dois questionamentos para direcionar a discussão neste capítulo:

Qual é o contexto de ensino e aprendizagem da escola participante da pesquisa?

O que a discussão de dois documentos oficiais pode informar sobre a prática dos professores de inglês?

Antes de apresentar os dados em consonância com as duas questões acima, faço um levantamento de como as políticas linguísticas têm sido abordadas como foco de investigação para a formação de professores.

\subsection{Políticas linguísticas e formação de professores de inglês}

As pesquisas sobre as políticas linguísticas em contexto internacional, durante muito tempo, de acordo com May (2008), estiveram associadas à concepção estruturalista de se conceber língua. Essa perspectiva, segundo a autora, voltava-se para os aspectos abstratos do estudo da língua, e particularmente enfatizava a preocupação com a resolução de 'problemas' imediatos relacionados aos contextos pós-coloniais da África, da Ásia e do Oriente Médio. Visava-se a unificação das línguas nacionais para se alinhar ao desenvolvimento das sociedades ocidentais. Neste período - que compreende as décadas de 60 e 70 - os estudos não levavam em consideração as condições políticas e sociais nas quais as línguas estavam inseridas. 
Pode-se dizer que durante essa fase, não havia nas pesquisas a preocupação de se criticar ou de se questionar os processos históricos que levavam a hierarquização das línguas dos falantes de grupos de maioria ou de minoria. Assim, a política linguística estava diretamente ligada à política do nacionalismo moderno e sua ênfase no estabelecimento das línguas nacionais e na homogeneização linguística vinculada à modernização e à ocidentalização. Neste sentido, a epistemologia europeia, também chamada de iluminismo, fundamentada na versão de desenvolvimento, acreditava ser capaz de 'resolver' os problemas de outros contextos do mundo. Essa visão etnocêntrica, conforme Said (2004), ignorava muitas realidades de outros países.

Para Jönsson (2010), é importante se admitir que o entendimento eurocêntrico da modernidade não apenas foi introduzido por acadêmicos e agentes do ocidente, mas também por intelectuais locais que consideravam o ocidente como modelo de modernidade e desenvolvimento. Em função disso, muitas elites não ocidentais eram e continuam sendo altamente influenciadas pelas ideias ocidentalizadas de desenvolvimento. No entanto, a noções de unidade e totalidades, os conceitos transcendentais de crença sobre conhecimento são contingentes quando se busca problematizar, entre outros aspectos, os seguintes questionamentos: Por que pensamos da forma como pensamos? Por que construímos certas visões particulares da realidade? Segundo o interesse de quem se apoiam determinadas normas e valores que tomamos como verdade? Ou ainda, o saber crítico poderia ser mais global com as interfaces do local, para se tentar responder onde estamos, por que estamos e a quem estamos servindo? Esses questionamentos são importantes 
para se discutir as interfaces das políticas linguísticas, dos planejamentos linguísticos e do ensino de línguas.

Ao pesquisar sobre políticas linguísticas, três termos são bastante recorrentes nas discussões: planejamento linguístico, políticas linguísticas e política linguística crítica. Amplio essa discussão ao acrescentar um quarto termo - letramento crítico das políticas linguísticas - pois acredito ser mais apropriado para o locus de investigação, neste capítulo.

Planejamento Linguístico (PL): termo usado principalmente nas décadas de 50 e 60, pode-se dizer que duas palavras-chave podem resumi-lo: intervenção e controle. Neste sentido, Tollefson (2009) se refere ao planejamento linguístico como esforços deliberados para interferir na estrutura, na função e na aquisição das línguas. Nos debates sobre a educação, uma discussão frequente sobre esse aspecto é o questionamento sobre que variedade deveria ser usada como meio de instrução em uma determinada comunidade, ou ainda, que línguas estrangeiras deveriam ser obrigatórias no currículo escolar. Por questões de poder, na escolha da variedade 'padrão', leva-se mais em consideração as que possuem mais prestígio. Identifico esse assunto nos questionamentos sobre que variante de inglês o professor fala, bem como na escolha feita pela escola ao priorizar uma ou duas línguas estrangeiras, como é o caso do inglês ou espanhol no Brasil. Em outras palavras, elas se tornam padronizadas como resultado de um processo social complexo no qual os grupos sociais moldam as atitudes linguísticas e, assim, as normas linguísticas são codificadas em dicionários, gramática, e posteriormente, legitimadas nos documentos oficiais, na mídia, nas escolas, entre outros contextos. 
Esse tipo de abordagem para o planejamento linguístico, segundo Blommaert (1999), não leva em consideração a agência humana, a intervenção política, o poder ou, ainda, a autoridade de uma ideologia nacional específica. Shohamy (2006, p. xv), por sua vez, argumenta que a "língua é dinâmica, pessoal e sem fronteiras definidas". Apesar disso, há sempre grupos e indivíduos que querem controlá-la e manipulá-la para promover ideologias políticas, sociais, econômicas e pessoais. Assim, a língua "é usada para criar filiações de grupos (nós/eles), para demonstrar inclusão e exclusão, para demonstrar lealdade e patriotismo, para demonstrar status econômico (haves/have nots) e classificação de pessoas e identidades pessoais" (Ibid, p. xv). Com isso, cria-se uma forma de controle, valorizando-se algumas variantes legitimadas como corretas, puras, próximas ao nativo.

A autora utiliza o termo mecanismos que, segundo ela, é definido como ferramentas da política linguística. Eles podem ser identificados nas sinalizações de rua, nas avaliações escolares, na política linguística da escola, nos testes de cidadania, entre outros. Levando em conta essas questões, Shohamy (2006) amplia o conceito de planejamento linguístico para políticas linguísticas.

Políticas Linguísticas: esse termo, segundo Ricento (2009, p. 13), despertou o interesse na academia da década de 70 até 90, principalmente de pesquisadores "com o interesse de compreender o papel da língua na reprodução das desigualdades social e econômica, influenciados pelas teorias críticas e pós-modernas". Os acadêmicos começaram a questionar os aspectos enfatizados pelos trabalhos anteriores do grupo do planejamento linguístico que reforçavam nomenclaturas como falante nativo, língua materna, 
competência comunicativa, ligados às teorias modernistas. Essas terminologias, no entanto, eram incoerentes com os contextos multilíngues existentes no mundo ou até mesmo dentro do próprio país.

Devido à complexidade das políticas linguísticas, Shohamy (2006) propõe que elas sejam consideradas em seu contexto mais amplo, ou seja, que sejam interpretadas por meio dos diversos mecanismos que são usados por vários grupos, particularmente aqueles de autoridade. Assim, não se limitam às políticas formais declaradas. A autora complementa que a política linguística é "o organismo primário para organizar, gerenciar e manipular os comportamentos da língua uma vez que consiste de tomadas de decisões sobre línguas e seus usos na sociedade" (Shohamy, 2006, p. 45). Neste sentido, é difícil estabelecer uma fronteira definida entre planejamento e política. Pode-se dizer que as políticas são menos intervencionistas e fornecem os fundamentos filosóficos e ideológicos, mas não estabelecem os passos de como se chegará ao objetivo final. Além disso, dependendo do contexto, há diferenças que podem aproximar ou distanciar os dois termos. Na prática, as políticas linguísticas se materializam em documentos, em leis e em regulamentações. No entanto, as políticas linguísticas não podem ser vistas apenas como declarações, mas que sejam avaliados os dispositivos que são usados para perpetuar as práticas linguísticas sejam elas implícitas ou explícitas.

Ao concluir, Shohamy (2006, p. 164) enfatiza que a política linguística é um "fenômeno muito mais complexo em que múltiplas agendas são surgidas, apresentadas, discutidas, negociadas e combatidas de maneira complexa e não previsível". A autora sugere que se considerem as várias 
entidades e categorias envolvidas no processo como, por exemplo, os indivíduos, os grupos, as nações, o transnacionalismo, ou ainda, outras ramificações que ainda podem ser desconhecidas.

Política Linguística Crítica: o movimento que buscou uma vertente de orientação epistemológica mais crítica, conforme Ricento (2009), surgiu no início da década de 80. Três críticas fundamentais foram levantadas pelo grupo da política linguística crítica em relação ao planejamento e política linguística que tomava como base os fundamentos acadêmicos ocidentais que assumiam: ideologias sobre: 1. A natureza da língua - finita, estável, padronizada, instrumento de comunicação gerenciada pelo governo. 2. Monolinguísmo e homogeneidade cultural como exigências necessárias para o progresso social e econômico, modernização e unidade nacional e seleção de língua como uma questão de "escolha racional" na qual todas as opções estejam igualmente disponíveis para todos ou que poderiam ser tornadas igualmente disponíveis. (RICENTO, 2009, p. 15)

Neste sentido, a política linguística crítica busca investigar como as ideologias são promovidas. As pesquisas nesta perspectiva, segundo Shohamy (2006), buscam analisar como fronteiras linguísticas são criadas na tentativa de se ter línguas puras, de se provocar inclusão ou marginalização de grupos, entre outros aspectos que violam os direitos pessoais e promovem práticas não democráticas.

A vertente ideológica, conforme Tollefson (2009), possui influência da linguística aplicada crítica que abarca a análise do discurso, os estudos de letramento crítico e a pedagogia crítica. $\mathrm{O}$ autor ainda relata que o termo crítico na política linguística critica possui três questões interrelacionadas: 
A primeira está associada às pesquisas tradicionais dominantes que valorizam as questões técnicas como o desenvolvimento de terminologias. As pesquisas, nesta vertente, não se preocupam com os aspectos políticos e sociais que afetam as políticas linguísticas. Tollefson (2009) denomina essa pesquisa tradicional como neoclássica que visa resolver problemas de comunicação em contextos multilíngues para aumentar a participação econômica e social das comunidades de minorias nos programas ligados à modernização de países em desenvolvimento, como na África do Sul. A crítica feita a esse enfoque é que a política linguística esteve ligada à política de desenvolvimento e, com isso, promoveu os interesses dos grupos dominantes e criou várias formas de desigualdades sociais e, consequentemente, levou ao descrédito da academia em relação às pesquisas sobre as políticas linguísticas tradicionais.

A segunda, conforme Tollefson (2009), está relacionada ao enfoque de pesquisas que visam à mudança social e à justiça social. Nela, as investigações buscam examinar o papel das políticas linguísticas com relação às desigualdades sociais, políticas e econômicas com a finalidade de se reduzir as várias formas de desigualdades. Inclui, entre elas, a preocupação com a revitalização das línguas indígenas e das heritage languages na tentativa de se obter justiça social. Tollefson (2009) também enfatiza que essa vertente possui a preocupação tanto com a ética quanto com a metodologia de pesquisa. Neste sentido, não há um distanciamento entre o objeto e o pesquisador, ou seja, não se fundamenta na objetividade do pesquisador como é o caso dos enfoques mais tradicionais. 
A terceira está ligada a pesquisas influenciadas pela teoria crítica. Nela, os estudos visam desvelar como as desigualdades são criadas e sustentadas. Investigam-se os processos pelos quais a desigualdade social é produzida e sustentada e busca-se reduzir a desigualdade com o intuito de trazer justiça social. As desigualdades aqui, segundo Tollefson (2009, p. 43) são vistas como "invisíveis devido aos processos ideológicos que naturalizam as condições do sistema social humano". Na teoria crítica, conceitos como poder são institucionalizados, como por exemplo, pelo intermédio de instituições como a escola que pode contribuir para a reprodução da desigualdade. Nesta vertente, segundo Tollefson (2009), os estudos visam repensar a teoria marxista e neomarxista sob a influência dos trabalhos de Bourdieu (1991), Foucault (1979), Gramsci (1988), Habermas (1987,1988), entre outros.

Apesar dos três significados possuírem características distintas, Tollefson (2009) destaca que eles não são mutuamente exclusivos e que a maioria das pesquisas reflete todos eles. $\mathrm{O}$ autor ainda explica que a teoria crítica influenciou as políticas linguísticas principalmente por dois aspectos aceitos pelos pesquisadores desta área: primeiro, devido às categorias estruturais como classe, raça e gênero por representarem fatores centrais na explicação da vida social, presentes nas pesquisas tradicionais. Segundo, porque considera que a epistemologia e a metodologia de pesquisa são inseparáveis dos padrões éticos e do compromisso com justiça social. Tollefson (2009) remete a Habbermas e seu argumento sobre o método crítico e a importância da avaliação auto-reflexiva da relação do pesquisador com os 'outros' são objetos de investigação. Além disso, destaca o próprio 
questionamento do termo pesquisa que remete à visão imperialista e colonialista europeia que coloca em desvantagens outros conhecimentos locais. Assim, na reavaliação da metodologia de pesquisa, alguns posicionamentos são importantes, conforme um levantamento feito por Tollefson (2009) ao resumir os questionamentos de alguns teóricos sobre esse assunto:

Como as diferentes comunidades discursivas, incluindo as os pesquisadores de políticas linguísticas estabelecem e mantém suas formas preferidas de conhecimento? (BLOMMAERT, 1996); O que conta como perguntas de pesquisa legítimas, metodologias de pesquisa aceitáveis e formas persuasivas de evidencias? (WILLIAMS e MORRIS, 2000); Que responsabilidades éticas os pesquisadores tem no processo de pesquisa? (SMITH, 1999); Como as formas preferidas de conhecimento são criadas e sustentadas entre os grupos afetados pelas políticas linguísticas? (CANAGARAJAH, 2002) Que papeis os 'Outros' deveriam desempenhar no processo de pesquisa, especialmente em avaliar a pesquisa? (RYON, 2002).

(TOLLEFSON, 2009, p. 45)

Nessas discussões, o fator de convergência dos pesquisadores é de que as pessoas que vivenciam a política deveriam ter o papel principal nos processos de elaboração das políticas como um princípio de participação democrática.

Letramento Crítico das Políticas Linguísticas: diferentemente de se buscar desvelar verdades e ideologias com influência da teoria crítica conforme discutido anteriormente, o letramento crítico das políticas linguísticas estaria voltado para o estudo das políticas linguísticas e a formação de professores, comprometido em investigar de que maneira elas são interpretadas, 
negociadas, resistidas ou reconceituadas conforme a tradução do conhecimento local/contextual dos professores. Inclui, ainda, a preocupação ética com postura autocrítica do pesquisador em assumir as suas próprias interpretações como parte integrante do processo colaborativo interpretativo em sua relação com o outro - o professor colaborador. Essa atitude busca ressignificar a atuação colaborativa do pesquisador para ampliar a sua percepção do contexto investigado em contato com o outro.

Embora haja várias perspectivas sobre letramento crítico (Luke e Freebody, 1997; Morgan, 2011, entre outros), optei por ressignificar três autores brasileiros: Freire (1996 [2002], 2005), Menezes de Souza (2011), abordados neste capítulo 2, e Monte Mór $(2011,2012)$ no capítulo 3. Apropriome de Freire $(2005)^{9}$ para fundamentar que o letramento crítico das políticas linguísticas tem o compromisso de estar com o mundo e, com isso, enfatizo a tomada consciência do pesquisador em relação a si mesmo em sua relação com o outro. Para o autor:

[...] a possibilidade de termos consciência do mundo e uma consciência de nós mesmos [...] se não fosse possível que um não eu de todos, um não eu, que era o mundo, consistisse eu. Quer dizer, foi exatamente o mundo, como contrário de mim que disse a mim você é você. E foi exatamente este eu que ficou eu, pela contradição do mundo como um teu meu, que me fez dizer que o mundo é este. Então a consciência do mundo, a consciência da presença do contrário, criou em mim uma consciência de mim. (FREIRE, 2005, p. 252)

\footnotetext{
${ }^{9}$ A partir de Menezes de Souza (2011), que ressignifou Freire (2005) para redefinir letramento crítico, vi também a possibilidade de ampliar a discussão para a interface entre políticas linguística e a formação de professores.
} 
Refiro-me a consciência das minhas concepções teóricas como pesquisador e como esta pode ser recontextualizada em contato com o outro [não-eu] diferente do eu [individualizado]. Essa postura também pauta-se no compromisso ético e não violento de impor ao professor colaborador as identidades teóricas do pesquisador como respostas imediatas para os desafios apontados pelo professor, segundo uma lógica emancipatória vertical (RANCIÈRE, 2010) conforme discuto no capítulo três, durante o processo colaborativo de discussão dos documentos oficiais.

Complementando o argumento acima, Menezes de Souza (2011, p. 131) afirma que "um passo importante para perceber a conexão entre o 'não eu' coletivo e o 'eu' no processo educacional de desenvolver a consciência crítica está na [...] importância de aprender a escutar/ouvir". O autor aqui discute a relação entre autor e leitor como sujeitos sociais que possuem percepções a partir dos seus contextos sócio-históricos. Neste raciocínio, o letramento crítico estaria comprometido em abordar como isso possui efeito no papel interpretativo. Para o letramento crítico das políticas linguísticas, recontextualizo as palavras autor e leitor de Menezes de Souza para pesquisador e professor. Nessa ótica, destaco principalmente a importância do pesquisador saber ouvir o outro e a si mesmo em um trabalho colaborativo. Para tanto, remeto-me a outra obra de Freire (2002) para fundamentar este posicionamento:

Não é falando aos outros, de cima para baixo, sobretudo, como se fôssemos os portadores da verdade a ser transmitida aos demais, que aprendemos a escutar, mas é escutando que aprendemos a falar com eles, mesmo que, em certas condições, precise falar a ele. O que jamais faz quem aprende a escutar para poder falar com é falar impositivamente. Até 
quando, necessariamente, fala contra posições ou concepções do outro, fala com ele como sujeito da escuta de sua fala crítica e não como objeto de seu discurso. O educador que escuta aprende a difícil tarefa de transformar o seu discurso, às vezes, necessário, ao aluno, em uma fala com ele. (FREIRE, 2002 [1996], p. 127)

No processo de escuta do professor, o pesquisador não procura identificar um problema levantado no processo colaborativo e, em seguida, buscar emancipar o outro com respostas prontas para o contexto que lhe é desconhecido. Implica, todavia, na escuta sensível para se tentar compreender o contexto do outro, para se identificar questões não imaginadas e para se perceber como o conhecimento local pode interferir nas percepções do pesquisador e vice versa. Em alguns momentos de interação, como ocorreu nesta pesquisa, o professor espera que o pesquisador escute as suas ansiedades e angústias em relação aos desafios do dia a dia da escola e lhe aponte alternativas. Neste tipo de situação, o pesquisador, imbuído de um sentimento emancipatório, pode sentir a necessidade de apresentar respostas prontas. Entretanto, tal procedimento pode não contribuir para o processo de construção de agência do professor e, ainda tal postura estaria associada à impositividade apontada por Freire (2002).

Essa discussão é ampliada por Menezes de Souza (2011) que destaca a importância da escuta ao abordar leitura crítica como um processo de ler o outro se lendo. Embora o autor se refira à leitura de textos, vejo aqui uma possibilidade de se remeter à política linguística crítica que considera o processo colaborativo na negociação de diretrizes curriculares. 
O processo de ler criticamente envolve [...] aprender a escutar as próprias leituras de textos e palavras. Isso quer dizer que ao mesmo tempo que se aprende a escutar, é preciso se ouvir escutando [...] então, em desempenhar dois atos simultâneos e inseparáveis: (1) perceber não apenas como o autor produziu determinados significados que tem origem em seu contexto e seu pertencimento sócio-histórico, mas ao mesmo tempo, (2) perceber, como leitores, a nossa percepção de significados e seus contextos socio-históricos e os significados que dele adquirimos. (MENEZES DE SOUZA, 2011, P. 132)

Identifico os dois aspectos levantados pelo autor sobre as diferentes percepções deste pesquisador e das professoras durante o processo de negociação de implementação de temas conforme as premissas do letramento crítico. A partir das discussões com elas, comecei a aprender a ouvir me ouvindo. Comecei a perceber nesse processo que algumas das minhas observações eram distantes do contexto da sala de aula das professoras. Embora eu estivesse bem intencionado ao apontar temas e textos para se abordar o letramento crítico nas aulas de inglês, o fato de termos contextos de formação sócio-históricos distintos, bem como experiências de sala de aula diferentes, os temas sugeridos pelas professoras demonstravam estar mais em consonância com as questões do dia a dia da escola no processo de ressignificação e implementação das propostas. No excerto a seguir, exemplifico essa percepção. Em um dos encontros, eu sugeri o tema violência a partir de um texto que abordava a corrupção dos soldados no Rio de Janeiro. $\mathrm{Na}$ negociação, as professoras ressignificaram minha proposta e identificaram o contexto de violência na escola e, a partir disso, a aula abordou diversos outros tipos de violência. Contemplaram com isso os problemas relacionados aos aspectos de violência na escola e na comunidade. 
P: Esse texto [...] talvez dê para começarmos por ele ou pelo menos podemos usar como uma proposta inicial [...] o que vocês acham?

P1: Eu acho que até pode interessar o $2^{\circ}$ ano que é mais maduro, até porque nós estamos com problema na escola. Acho que poderíamos trabalhar com a questão da violência dentro da escola [...] seria interessante.

$P$ : Como vocês gostariam de abordar na escola?

P2: Porque esse texto é típico lá do Rio.

$P$ : É do Rio, mas não quer dizer que o que está sendo abordado só aconteça lá.

P2: Há pouco tempo [...] na semana passada a TV mostrou uma inspetora de uma escola de São Paulo incentivando a filha a brigar dentro da escola. Ela falava assim: Bate minha filha, faz o que eu te ensinei em casa, dá um chute na cara dela. Aí isso teve uma repercussão bem grande aqui entre os alunos. $E$ um problema que temos aqui na escola. Ontem mesmo chamaram a patrulha por uma briga de menina. Agora não sei o link que a gente pode fazer desse texto com essa questão da violência aqui.

$P$ : Mas não precisa ser este texto, trouxe este para ver como a gente pode trabalhar a questão da violência, da inserção da multimodalidade, do letramento crítico [....]

P1: Então, porque a gente pode mostrar o trailer do Tropa de Elite e entrar neste texto e daí desse texto a gente pode fazer um link e chamar atenção para a violência na escola. Porque isso vai gerar uma discussão bem grande [...] Eles tem várias histórias de violência para contar.

$P$ : E também pode expandir o tema violência para vários contextos.

P2: Porque não temos favelas em Campo Grande como descritas no texto.

P1: Ou entrar na internet e acessar os jornais locais, todos têm manchetes de violência. 
P2: Eu acho que primeiro o texto e depois vamos para a sala de vídeo porque ai começa a estabelecer relação com o texto [...]

$P:$ Não tem receita, depende do seu contexto [...]

P1: Porque o vídeo vai despertar uma discussão. Ai depende [...] também tem que ver o conceito deles de violência né?

$P$ : Isso é interessante porque estávamos partindo do pressuposto do que a gente achava né?

P2: Eu acho que essa questão da violência [...] a gente iria fazer um trabalho bem legal se a gente voltasse para a violência na escola, eu ainda penso assim.

A perspectiva do letramento crítico das políticas linguísticas possui interface com a discussão de Menken e Garcia (2010). Para esses autores, não é possível compreendermos as políticas linguísticas sem estudarmos as práticas situadas. Afirmam, ainda, que independentemente do tipo de política ou contexto educacional, há sempre espaço para contestação, enfatizando-se, assim, o aspecto da agência dos que recebem os documentos. Nesse sentido, as noções de percepção crítica dos professores, bem como a escuta cuidadosa do pesquisador são dois aspectos importantes no processo de negociação dos documentos no processo colaborativo. Para tanto, Monte Mór (2012) acrescenta que as políticas linguísticas não podem ser dissociadas da educação. Para a autora, não se trata mais de se olhar para modelos do passado, uma vez que a época atual não prioriza modelos convergentes, aceitando as heterogeneidades linguísticas, culturais e sociais entendendo, portanto, ser mais importante saber lidar com os conflitos e contradições.

Outro aspecto bastante relevante é levantado por Menezes de Souza (2012) ao afirmar que política pressupõe comunidade: "se política pressupõe comunidade, para se ter uma comunidade precisamos ter 
homogeneidade porque comunidade é sempre um desejo de se excluir a diferença" (em vídeo). No entanto, o autor esclarece que comunidade apenas enfatiza o que temos em comum e que igualdade não é sinônimo de homogeneidade e afirma que esses aspectos são muito difíceis de serem contemplados nas políticas. O autor então indaga: "como as políticas podem considerar a heterogeneidade no nível regional sem serem apenas objetos simbólicos? Não saber como usar é uma questão de não saber traduzir?". Percebo que a preocupação com a homogeneização e padronização está presente no documento do Referencial Curricular para o Estado de Mato Grosso do Sul. No entanto, mesmo com todos os mecanismos da secretaria de educação que tentam garantir tal padronização, como os planejamentos pautados em listas de conteúdos pré-estabelecidos, não há garantias que isso irá acontecer, uma vez que a implementação depende das lentes culturais do professor. Por outro lado, quando o documento é mais aberto para reinterpretações, como é o caso das OCEM, os professores relatam que precisam de algo que thes dizem como fazer. Menezes de Souza (2012) complementa que o desafio não é o do documento em si, mas um problema das nossas epistemologias que nos fazem olhar para a homogeneidade dos documentos. $\mathrm{O}$ autor sugere que precisamos quebrar este ciclo e olhar para as línguas, e aqui, remeto aos documentos, de outra maneira. Neste sentido, o trabalho com o letramento crítico das políticas linguísticas a partir de uma lógica horizontal de colaboração nas pesquisas demonstradas neste estudo pode contribuir para quebrar esse olhar para os documentos. 


\subsection{O contexto escolar, os conflitos de objetivos e o ensino da língua inglesa em uma sociedade globalizada}

Após a discussão sobre políticas linguísticas e os principais enfoques de pesquisa, retomo as duas perguntas de pesquisa:

\section{Qual é o contexto de ensino e aprendizagem da escola} participante da pesquisa?

O que a discussão de dois documentos oficiais pode informar sobre a prática dos professores de inglês?

Durante o primeiro semestre de ano de 2009, busquei registrar o contexto do ensino médio da escola em questão, bem como investigar os objetivos das professoras em relação ao ensino da língua inglesa neste segmento. Essas categorias foram identificadas após os encontros. Durante os primeiros encontros com as professoras, dois aspectos importantes emergiram. O primeiro levantou o conflito de objetivos sobre o ensino do inglês na escola. O segundo evidenciou o ceticismo das professoras em relação ao lançamento de vários documentos voltados para o mesmo segmento e como isso se refletiu nas identidades teóricas das professoras.

O desafio de se trabalhar com salas heterogêneas foi uma das principais preocupações das professoras em relação ao contexto de ensinoaprendizagem da escola. Nesse cenário, o desnivelamento linguístico dos alunos parecia causar desconforto nas professoras, conforme o relato a seguir.

P2: O problema [...] principalmente o primeiro ano, aqueles que ficaram parados há 10, 15, 20 anos não acompanham o pessoal mais jovem, por mais que ele não tenha um baixo rendimento, não acompanha, não vai. Essa às vezes é a nossa angústia, ou você para tudo e começa do zero por causa daquele ou você não sabe quem você socorre. $E$ como as salas são muito heterogêneas né, então a gente fica assim. Eu 
gosto muito de trabalhar com texto né [..] mas aí fica difícil. (grifos do pesquisador)

A partir deste excerto, ao mencionar que uma das alternativas para o direcionamento das aulas seria iniciar o planejamento da aula a partir do nível 'zero', interpreto que a preocupação principal da professora 2 era em relação ao ensino da língua inglesa com foco na gradação. O conhecimento do aluno tido como nulo parece estar associado à forma tradicional de mensuração da língua, de unidades simples para as mais complexas. A partir desse depoimento, também posso inferir que há comprometimento da professora em buscar uma alternativa para que o aluno acompanhe 0 andamento das aulas. Contudo, a situação de heterogeneidade dos alunos causa desconforto para as professoras investigadas. A partir dessa consideração inicial, a aprendizagem da língua poderia ser considerada como um processo gradativo. Associo essa situação às constatações apontadas por Monte Mór (2011, p.66), ao discorrer que o ensino de língua estrangeira tem sido tradicionalmente pautado por "uma sequência definida de prioridade", com ênfase no enfoque linguístico, de forma linear. Nessa perspectiva, o aluno começa a estudar as estruturas mais simples e, gradativamente, passa para as estruturas mais complexas. Essa questão também foi identificada no referencial do primeiro ano (ver anexo 1), no qual os conteúdos são dispostos bimestralmente conforme uma sequência linear de gradação apresentada em forma de tópicos gramaticais.

O enfoque dos conteúdos pautados na gradação também foi evidenciado por outra participante durante a discussão. A professora 1 exemplifica o caso de alunos transferidos de outras escolas que não acompanham os demais estudantes da turma. 
P1: Então [...] é o que ela falou, por que daí você tem que começar do básico. Eles chegam aqui sem vocabulário nenhum [...] Eu coloquei um questionário de sondagem pra ver a turma [...] ele coitado fica perdido [...] Mas no caso desse aluno ele vai ter que carregar um dicionário agora, o que eu posso fazer? Eu não posso voltar a turma parar para ensinar o vocabulário básico por causa de um aluno que eu tenho ali, né. Então ele vai ter que dar os pulos dele. (grifos do pesquisador)

Semelhantemente à professora 3 , a professora 1 reflete a preocupação em relação aos alunos provenientes de outras escolas que não acompanham a turma da escola em questão. Novamente, a alternativa encontrada pela professora seria iniciar o planejamento das aulas a partir do nível básico. Por outro lado, ela demonstra que essa alternativa poderia prejudicar a aprendizagem dos demais alunos. Parece haver certa exclusão dos alunos que possuem dificuldades em acompanhar a aula, uma vez que 0 enfoque das aulas estaria direcionado ao aspecto linguístico. Para compensar o desconhecimento do léxico, o dicionário foi uma ferramenta encontrada para minimizar tal dificuldade.

Essas constatações refletem uma tradição educacional de como os conteúdos têm sido comumente considerados. Nesse sentido, Monte Mór (opt. cit.) e Morin (2000) criticam o problema do ensino tradicional e apontam dois princípios que regem a consciência cientifica: a redução e a separação. Associo essas duas perspectivas às considerações das professoras pesquisadas, exemplificadas pelas expressões "sem vocabulário nenhum, começar do básico, questionário de sondagem". Esses argumentos ilustram a tentativa de mensuração que é uma das características do princípio da redução 
que, segundo Morin $(2008, p .88)$, "tende a limitar o conhecimento a algo que seja "mensurável e quantificável". Não busco, contudo, criticar a posição das professoras por determinadas escolhas. Evidencio, a partir desse excerto, que as questões apontadas por Morin e Monte Mór são muito fortes nos contextos pedagógicos, bem como na distribuição dos conteúdos dos livros didáticos, em propostas curriculares como foi exemplificado no anexo 1.

Embora a gradação tenha sido apontada nos dois excertos anteriores, a Professora 2 demonstra consciência desse fato, conforme pode ser identificado no excerto a seguir:

P2: Na verdade, dessa forma a gente tem que entender que 0 ensino é fragmentado em segmentos. Então inglês é pior ainda. Matemática: o aluno estuda e não sabe o que viu antes. Português: ele vê a vida inteira a mesma coisa. História: a mesma coisa. Inglês não seria diferente, é pior por ser outro idioma, outra cultura. (grifos do pesquisador)

A partir dessas considerações, a Professora 2 faz uma crítica sobre a fragmentação dos conteúdos e que essa constatação se aplica a várias outras disciplinas, contribuindo, assim, para o fracasso na aprendizagem. Por outro lado, até esse momento da discussão, a professora ainda não apresentava nenhuma outra possibilidade metodológica para o ensino da língua inglesa na escola em questão.

Comparativamente às outras disciplinas, o caso do Inglês parece estar em uma categoria menos favorecida em relação à dicotomia fragmentação e aprendizagem. A situação, segundo o relato, seria agravada por se tratar "de outro idioma, outra cultura". A afirmação levanta uma questão importante sobre o status da língua inglesa, conforme discutido no capítulo 1. 
Ao apontar os pronomes 'outro' e 'outras', a professora demonstra uma visão colonialista da língua, conforme apontado por Pennycook (2007). Nesta perspectiva, o inglês e a cultura estariam representados pelo círculo interno ou externo, conforme a divisão da sociolinguística, proposta por Kachru (1985), apresentada no capítulo anterior. No entanto, ainda é prematuro fazer essa afirmação nesta pesquisa, uma vez que essa interpretação foi apenas inferida a partir dos pronomes outros e outras. Retomo essa discussão mais adiante na interpretação dos documentos oficiais.

A discussão inicial sobre o contexto escolar abriu espaço para se discutir a função da língua inglesa no currículo. Nos excertos a seguir, a falta de perspectiva por parte dos alunos, o foco no vestibular e a dicotomia no público e privado emergiram na interação com as professoras.

P3: Eles não valorizam, eles não veem um porque de aprender uma segunda língua mesmo que você tente mostrar a importância. Eles não sabem o porquê que eles tão aprendendo, para eles, não vão usar isso em lugar nenhum.

P3: Mas o ano passado eu tive problema, porque o aluno falou pra mim que ele não tinha intenção de fazer o vestibular [...]. Ele falou: não interessa, eu vou ser bandido, vou ser traficante. (grifos do pesquisador)

No primeiro excerto, a professora 3 relata a desmotivação dos alunos em aprender a "segunda" língua. O tratamento de segunda língua, apontado pela professora 3 , pode reforçar valores dicotômicos como primeira língua/segunda língua, falante nativo/não nativo conforme apontado por Bhatt (2010) e discutido no capítulo 1. O uso do Inglês, segundo a explicação da professora em relação ao relato dos alunos, estaria limitado à questão espacial: 
"em lugar nenhum". A noção de língua como worldliness, apontado por Pennycook (2010) e Mignolo (2000) em que a língua não estaria ligada à referência de espaço, pertencimento, local de origem, talvez pudesse contribuir para a desconstrução de tal percepção por parte do aluno.

A visão de uso da língua também pode estar associada ao conceito de motivação instrumental, conforme discutido por Norton (2000). Para a autora, essa visão, influenciada pelos modelos de aquisição de língua, estaria relacionada ao aluno ter que aprender uma segunda língua na escola para propósitos utilitários como, por exemplo, para o emprego. Este tipo de enfoque desconsidera a complexidade do processo educacional entre poder, identidade e língua e, com isso, pode não haver o investimento ${ }^{10}$ do aluno.

Apesar da forte tendência que beneficia 0 inglês e exclui outras línguas, o relato do aluno demonstra uma visão contrária ao forte discurso da globalização sobre a necessidade de se falar inglês com o objetivo de se ter acesso e participação no fluxo global de capital econômico e cultural. O valor simbólico, na acepção de Bourdieu (2001), atribuído à língua inglesa é criado e socialmente autorizado por meio de vários tipos de métodos retóricos que asseguram a produção estável de assimetrias linguísticas disciplinares. Para Bhatt (2010, p. 101), o discurso dominante "produz um público, contexto e texto

\footnotetext{
${ }^{10}$ Para Norton (2000, p.10), a motivação estaria relacionada a "propósitos unitários, fixos, e ahistóricos dos aprendizes da língua que desejam acessar recursos materiais que são privilégios dos falantes da língua alvo". Investimento, por outro lado, estaria relacionado ao compromisso dos aprendizes com sua aprendizagem.

A autora usa a metáfora de investimento com base no conceito de capital econômico de Bourdieu: "se o aprendiz investir em uma segunda língua será com o entendimento de que adquirir uma grande variedade de recursos materiais e simbólicos aumentará o valor do seu capital cultural." (Norton, 2000, p. 10)
} 
no qual a estrutura parece ser óbvia." Assim, segundo o relato da professora, o local parece não sofrer efeito da 'doutrinação' do inglês como segunda língua e, com isso, parece não atingir essa comunidade de alunos. Além disso, o terceiro ano do ensino médio pode representar o início do processo de seleção para o ensino superior. No entanto, o relato do aluno não reflete a perspectiva de continuidade dos estudos quando opta por outra perspectiva de trabalho que não seja via educação.

Estas questões me fizeram refletir sobre a função do inglês na escola e, com isso, direcionar a discussão com as professoras sobre os objetivos do inglês na escola. Percebi, também, a necessidade de se propor um trabalho educacional voltado para letramento crítico e, dessa maneira, abrir espaço para discutir questões sobre o papel do inglês e o ensino fragmentado. Até esta etapa do trabalho, eu acreditava que poderia emancipar as professoras e trazer a "luz" para os problemas levantados, conforme uma perspectiva emancipatória tradicional ligada a visão de empoderamento apontada por Jönsson $(2010)^{11}$. No entanto, essas questões foram posteriormente redefinidas pelas próprias professoras que começaram a construir suas próprias agências. Com isso, comecei a perceber como o conhecimento local estava em constante modificação, em processo no qual as verdades são contingentes, conforme discuto na segunda fase da pesquisa.

\footnotetext{
${ }^{11}$ Para a autora, empoderamento representa os esforços de grupos marginalizados para um ambiente livre de desigualdades que os desfavorecem social, político e economicamente, fundamentado por uma visão modernista de desenvolvimento, ligado a categorias de desenvolvido e subdesenvolvido, com atitudes paternalistas que consideram o outro como pessoas que esperam para serem salvas.
} 
A comparação entre o sistema educacional público e o privado foi bastante evidenciada nas discussões. Na primeira fase do projeto, as Professoras 1 e 2, que atuavam tanto no contexto público quanto no privado, demonstravam mais identificação com o setor privado, sendo este o local cuja função do inglês fazia mais sentido. No entanto, a consideração inicial em relação ao local começa a ser redefinido na segunda fase. Os depoimentos a seguir ilustram a primeira fase.

P1: [...] eu tenho 2: a particular e a realidade pública [...] Lá na particular [...] os que entraram pra inglês entraram numa ânsia de querer leitura [...] Aqui [..] mas ele não entende, mesmo você pegando texto, trabalhando com ele, dá as dicas, explica as estratégias, não sei, parece que é outra realidade realmente.

P3: Não veem, são poucos os alunos quem veem o vestibular como foco.

P2: Porque o que eu sinto é que o inglês é muito fragmentado. De repente a gente chega esperando um conteúdo de lá atrás e não tem. Trocam a sequência. Às vezes eu tento trabalhar com uma sequência, mas falta a base lá atrás. (grifos do pesquisador)

As três narrativas demonstram que os alunos do contexto público não manifestavam interesse em continuar os estudos. No primeiro excerto (Professora 1), a habilidade de leitura é destacada com ênfase no aspecto cognitivo. No entanto, o uso de estratégias parece funcionar mais no contexto particular, uma vez que os alunos deste contexto serão submetidos ao exame do vestibular. A leitura, nesse excerto, representa uma visão cognitiva, influenciada pelo modelo psicolinguístico que se preocupa com os "problemas 
de aquisição individual", conforme apontado por Street e Leung (2010, p.303). A partir dessas considerações, a perspectiva etnográfica para compreender as práticas de letramento em contexto situado proposta pelos novos letramentos me ocorreu com uma possibilidade. Essa discussão com as professoras poderia ser futuramente viabilizada a partir da leitura das OCEM. No último excerto, a professora 2 insiste no argumento da fragmentação e admite que mesmo quando adota uma perspectiva de sequência, a aprendizagem parece não ocorrer.

Após as considerações iniciais sobre o contexto da escola, direcionei a discussão para as alternativas encontradas pelas professoras para o ensino da língua inglesa, considerando as dificuldades apontas. A professora 3 relata a tentativa de se ensinar a língua por meio de projetos.

P3: Eu estava falando para Professora 2 [...] ano passado [...] que eu tenho que melhorar meu planejamento [...] de como eu fiz [...] eu fiz sem nem sabe que aquilo ali era um projeto. Então [...] mandei fazer um trabalho todo de folclore, fazer comparações com o folclore de lá, se havia mesmo folclore com o folclore daqui. $O 2^{\circ}$ ano foi trabalhar com o uso da língua [...] quem são aqueles povos. [...] (grifos do pesquisador)

O projeto proposto pela professora relaciona-se ao aspecto cultural da língua por meio de pesquisa utilizando o laboratório de informática. As menções "folclore de lá" bem como "aqueles povos" parecem remeter à referência de língua e cultura britânica ou norte americana. Esta perspectiva de comparação de culturas e língua é uma das sugestões apresentadas no Referencial Curricular do Estado de Mato Grosso do Sul (2006), que aconselha ao professor emitir juízo crítico das culturas e dos povos falantes da língua. (ver 
competências e habilidades no anexo 1). Sobre esse aspecto, Kress (2008) questiona as orientações dos currículos que têm como base transmitir às gerações conteúdos, seja conhecimento ou habilidade, com valores naturalizados.

Neste sentido, Kress (ibid, p. 255), aponta que "não é mais possível ensinar uma língua sem, ao mesmo tempo, ensinar sobre aspectos relevantes da cultura." Em outras palavras, no caso do inglês, a professora 3 faz referência ao 'folclore de lá', 'aqueles povos', e supostamente estaria se referindo ao contexto americano, inglês, australiano, ou algum outro. Kress, então questiona se estamos ensinando a cultura desses locais e levanta as seguintes perguntas: se formos generalizar, que cultura ou aspectos culturais seriam pontos de referência em um contexto global? E nesse contexto, sob o poder de quem? Com que autoridade e como isso é exercido? Parece-me que nesse exemplo apontado na fala da professora 3, o aspecto cultura é visto apenas para explorar as curiosidades sobre semelhanças e diferenças entre as duas culturas. No entanto, não se pode afirmar sobre o 'lá' e o 'outro" com relação ao ponto de referência.

No que concerne ao andamento do projeto, a professora expõe os conflitos que emergem nas aulas, conforme observamos a seguir:

P3: Duas aulas é muito pouco tempo, ainda mais nós que temos que apresentar [...] aí falta tempo para dar o conteúdo da parte gramatical. Aí tem aquela leitura que você vai ter que fazer que acaba não fazendo, aí às vezes não dava para conferir a aula por causa de um acontecimento ou outro, e aí você tinha que fechar o bimestre, você tinha que ter tempo para essas explicações de conteúdo e a nota. (grifos do pesquisador) 
A possibilidade de se adotar uma proposta voltada para projetos não permite a professora cumprir o currículo da escola. A primeira limitação referese ao tempo de aula. Ainda assim, a carga horária da escola se assemelha à realidade da maioria das escolas regulares. O projeto apresenta-se dissociado do aspecto linguístico, tanto do conhecimento sistêmico, como também do textual. Assim, interpreto que o conflito da professora nesta narrativa está em conciliar o projeto temático com os conteúdos curriculares. A seguir, a professora relata 0 insucesso de tal tentativa de se trabalhar com o aspecto cultural.

P3: [...] eu acho que é uma proposta boa, eu acho que eu tive um bom trabalho, mas o que eu percebi é que eu não consegui despertar o interesse de todos [...] Eu tenho que fazer alguma coisa, e não tem o que fazer. E aí você faz, você prepara, você dá a aula, você monta. Eu pesquisei, antes de eles irem lá, eu fui à internet pesquisei todinho. Eu fiz o meu trabalho, então eu sabia mais ou menos o que poderia cair ali, quem eles poderiam escolher. Eu nunca soube tanto de Shakespeare como eu soube ano passado dentro da literatura, então eu sabia que ia cair na mão deles o Shakespeare e eu sabia explica isso para eles [...] (grifos do pesquisador)

Nesse relato, há um paradoxo entre a perspectiva da professora e a receptividade dos alunos em relação ao projeto. De um lado, a professora avalia positivamente o seu trabalho, afirmando que aprendeu muito sobre literatura. De outro, os alunos não corresponderam a esta expectativa. É acentuada, no excerto acima, a preocupação em relação ao controle sobre a produção dos alunos. Embora os alunos estivessem pesquisando no 
ciberespaço, a professora preocupava-se em verificar os possíveis caminhos e até mesmo prever o tipo de perguntas que surgiriam nas etapas de pesquisa.

Interpreto que a frustração da professora 3 poderia estar relacionada a duas questões importantes: a primeira em relação à impossibilidade de controle da professora e a segunda em relação a não conseguir corresponder às expectativa dos alunos. A finalização do projeto resultou na produção oral em português do tema pesquisado. Assim, os alunos desempenhavam um papel mais próximo a de consumidores de informação do que propriamente ao de produtores de significados. O processo de autoria poderia ser possibilitado por um trabalho de letramento digital, pois era o ambiente onde a atividade inicial foi desenvolvida. Assim, associado ao argumento de Lankshear e Knobel (2007), apesar da digitalidade (technical stuff), não houve nesse contexto a percepção da professora quanto à revisão conceitual (ethnos stuff) proposta pelos novos letramentos.

No excerto a seguir, a professora 3 expõe a sua frustração à recepção dos alunos.

P3: Então eu fiz essa pesquisa, aí eu percebo o seguinte: olha o meu caderno tem todinho, quem era o assunto, procurava encaminhar, procurava ver a pesquisa que eles faziam, acompanhava mais ou menos, tinham muitos que não achavam, eu orientava eles para ir por outro caminho. Mas diante disso, você cria uma ansiedade em você, não vou dizer que isso é desgastante, mas é frustrante. Aí você chega diante de uma turma, porque minha maior frustração lá era $o$ $2^{\circ}$ ano, que eu achava que tinha tudo entendeu, era uma coisa legal, uma coisa gostosa. Ainda até meu filho falava assim: Mãe é o que a senhora gosta, você tem que entender que uma coisa é diferente, a senhora é professora e nós somos alunos, então os nossos gostos são diferentes dos seus. 
(grifos do pesquisador)

A partir deste excerto, interpreto que o papel da professora representava $\circ$ modelo de transmissão. Embora o conhecimento nessa atividade apresentava-se de forma distribuída pela característica da pesquisa, mesmo assim, ela orientava os alunos sobre os passos a serem executados. A falta de controle da professora sobre os passos dos alunos causava ansiedade e frustração. Interessante constatar que, para a professora, a atividade era motivadora, para os alunos, no entanto, não houve a mesma satisfação. A partir do início do excerto, interpreto que a professora estava presa ao letramento tipográfico, que de acordo com Gee (2011), possui autoria definida enquanto que o trabalho de pesquisa dentro do ambiente virtual caracteriza-se por uma perspectiva pós-tipográfica. Esta outra perspectiva possui um caráter multimodal, com seus vários modos de representação pelos quais o conhecimento apresenta-se distribuído e possui caráter colaborativo, dinâmico e instável.

No que se refere à escolha do tema, o próprio aluno apontava onde o conflito poderia estar, ou seja, as divergências do que poderia ser importante ou motivador para aquele contexto. A preocupação da professora em transmitir um conhecimento canônico literário, poderia representar um privilégio intelectual para um grupo ou para a própria professora. No entanto, o local demonstrou que esse conhecimento não possuía tanta importância para ele. Diante desse relato, propus a seguinte reflexão para a professora: Qual seria então o gosto desse aluno hoje? Prontamente, a professora respondeu: 
percebe o seguinte professor, que tem lá, tem uns 40 alunos lá no $1^{\circ}$ ano, então de cada fileira tinham uns 2 ali, o restante, visivelmente não estavam interessados. Então aí eu me pergunto, o que eu vou fazer para esse restante? Porque eu vejo assim, eu posso não fazer o mesmo planejamento para turmas diferentes de mesma série, mas eu tenho que ter um norte e também assim [...] e se eu for falar de leitura [...] e se eu for falar de estratégias, e se eu vou aplicar um questionário. Agora eu não me vejo fazendo assim, essa turma gostou desse tipo de coisa, eu vou fazer assim. Já aquela turma não gostou, então eu vou mudar, isso aí eu não consigo. (grifos do pesquisador)

Embora a escola fosse orientada por um currículo prescritivo, com conteúdos distribuídos bimestralmente, o relato demonstra que isso não representa um "norte" conforme problematizado pela professora. A falta de conhecimento sobre a perspectiva do aluno dessa comunidade e as tentativas de implementação de projetos com pouco sucesso causam conflitos na atuação da professora 3. Há preocupação com a mensuração através da aplicação de questionário, bem como a predisposição de propor atividades diferenciadas nas diferentes salas. Contudo, a perspectiva do 'novo' representa um desafio para essa professora que até então não visualizava uma alternativa.

P1: Primeiro a gente precisa conscientizar esse aluno de que aprender uma segunda língua é uma forma de se tornar um cidadão, aí a gente tem que encontrar uma forma, um caminho que ele leve isso à sério, mas a maioria não quer levar isso à sério. (grifos do pesquisador)

A discussão que até então teve um foco linguístico e motivacional, passa agora a se preocupar com o aspecto educacional. No entanto, até o 
momento não se pode identificar que perspectiva em relação ao conceito de cidadania a professora está se referindo. Essa questão é retomada pela professora 1 nessa primeira etapa da pesquisa. Para clarificar 0 posicionamento e como isso se traduziria na aula de inglês, fiz o seguinte questionamento:

$P:[. .$.$] conscientização [..] a primeira parte é de conscientizar,$ aí uma vez que ele (o aluno) está consciente, o que viria a seguir?

A resposta dada não se referia ao aspecto de percepção crítica ou cidadania conforme havia sido proposto anteriormente. A professora questionou apenas a ênfase na estrutura linguística que era dada no ensino fundamental e argumentou que o documento federal não apresentava esta proposta, conforme o excerto a seguir.

P1. Olha professor, é assim, eu olho o lado prático, porque ensinar gramática envolve o EM, se o aluno tem os 4 anos pra aprender toda a gramática? O referencial curricular do MEC quase que em momento algum fala em gramática, na maioria das vezes ele fala em leitura. (grifos do pesquisador)

Naquele momento, percebi que seria oportuno, então, direcionar a discussão para a comparação entre os documentos que supostamente norteariam o ensino da escola em questão.

$P:$ E do Estado?

P1: Eu fiz até um paralelo [...] entre o nosso e o do MEC, organização curricular, como é o nosso e o do MEC. A participação na elaboração do documento, quem participou do MS e quem participou do MEC [...] aqui (MS) dentro tem situações assim, só que o que está aqui para por em prática não tem aqui, tem lá, então o que aconteceu? Se perdeu no 
caminho ou foi feito por pessoas não capacitadas? Porque aqui você não tem muito o que fala, tem que trabalhar gramática, tópicos gramaticais, isso e isso. (grifos do pesquisador) (VER ANEXO 2)

A Professora 1 questiona inicialmente o 'despreparo' da equipe que elaborou o documento oficial de Mato Grosso do Sul. O advérbio aqui, apontado pela professora refere-se a duas seções dos documentos, o das competências e habilidades e a lista de conteúdos (ver anexo 1). O que é sugerido na primeira parte não é contemplado na segunda. A única orientação, interpretada pela professora a partir da listagem de conteúdos do documento, é o foco no aspecto gramatical.

Após a discussão inicial sobre os dois documentos, abordo, então, o papel das tecnologias digitais no processo de ensino aprendizagem de língua inglesa, conforme o trecho abaixo.

P: Tem a questão da tecnologia, o que temos que trabalhar com o ensino médio? [...] antes nós lermos com mais detalhes as duas propostas e abordar outras questões.

P2: Acho que tem que trabalhar a propaganda no geral, revistas, músicas, porque eles têm um estilo, eles gostam de rock, eles gostam de Hip Hop, mas na verdade eles gostam do som, mas não sabem do que tá se tratando, [...] eu estava falando sobre o que é uma estratégia, muitas vezes quando você pega o texto e leva pra sala de aula, para fazer uma atividade, é aula de inglês e tal, eles já não gostam do professor, então eles ficam revoltados e não se ligam no texto e uma das estratégias[...] E aí comecei a trabalhar com eles, por exemplo né, eles andam com camiseta e geralmente tem aluno que chega pra gente e pergunta: "professora, o que tá escrito aqui?". Esses aí são curiosos né, eles querem saber o 
que está escrito, o que é aquilo na camiseta do colega. Aí o outro lá tinha escrito algo do time [...] (grifos do pesquisador)

Em vez de abordar o aspecto relacionado ao uso da tecnologia digital, a professora 2 limitou-se a discutir sobre o aspecto do trabalho com 0 gênero propaganda. A professora também retomou a discussão sobre 0 desinteresse dos alunos. É comum entre as três professoras o trabalho com as estratégias de leitura. No entanto, nos três casos, os alunos parecem não corresponder ao trabalho com o uso de textos. Evidencia-se também que há uma tentativa da professora 2 em contextualizar a aprendizagem por meio de frases de camisetas, mas essa atividade aparentemente se limita a curiosidades sobre o que os alunos usam.

A percepção de que os alunos gostam de hip hop e o desconhecimento do significado do que se canta poderia ser utilizada para explorar os fluxos culturais, bem como a percepção dos world Englishes, discutidos por Pennycook (2007), discutido no capítulo 1. Embora ainda fosse uma discussão inicial, o exemplo da professora sobre o hip hop poderia ser associado às discussões de Pennycook (2010). O autor afirma que embora o hip hop não seja um fenômeno novo, somente o termo possui essa conotação. A partir dessa brecha deixada pelo o aluno, a professora poderia promover uma discussão sobre as escolhas linguísticas, a relação do inglês com as línguas locais, as políticas de identidades e o uso desse produto cultural global e suas interfaces com as lutas de poder, as questões de agência, identidade e representação política e, principalmente, como os falantes organizam um gênero que é simultaneamente global e local, que se conecta a redes transnacionais e como isso faz sentido para esses alunos da escola em 
questão.

No entanto, naquele momento, não considerei oportuno levantar essas questões por se tratar de um espaço em que eu, como pesquisador, pudesse fazer um levantamento do contexto sob investigação, mas também das professoras não sentirem o seu espaço invadido por um externo e que poderia ser retomado quando fossemos abordar o aspecto local e global, levantado pelas OCEM. Como foi muito evidente nas narrativas da professora o trabalho com as estratégias de leitura, questionei então sobre a linguagem oral.

$P$ : E oralidade, é difícil trabalhar no EM, será que é o foco?

P2: Na oralidade eles já chegam com aquela vergonha de falar, travam, você pede pra eles falarem, para repetirem, pede para ele ler alguma coisa, pega e corrige mas ele trava, morrem de vergonha, tudo para não paga mico na frente do colega. Eu já deixo bem claro que ninguém tá ali para rir de ninguém, estão ali para aprender.

P1: Mas é difícil né Professor, com os pequenos é uma maravilha, 6ํㅜ $7^{\circ}$ anos você bota para falar e eles adoram, agora, começou a ficar maiorzinho e pronto, EM esquece. $E$ eles já vem com essa concepção de que eles estão na escola não é para falar o inglês, eles pensam que é igual qualquer disciplina, quando tem aula de geografia você não fica falando de geografia, parece que a impressão que você tem é que para eles é a mesma coisa, você só vai escrever, você não vai nem ler, não vai falar, não vai ouvir. Então você coloca o som para ouvir, numa sala de $\mathbf{4 0}$ alunos, para eles ficarem em silêncio é complicado, aí quando você consegue deixar a sala em silêncio tem o barulho da sala ao lado.

P2: Nada é o gosto deles, o problema é o conhecimento, a segurança no vocabulário, em leitura. Quando eu levo alguma coisa pronta, eu trabalho com eles repetindo, se eu 
começo a fazer perguntas eles me respondem, eles vão respondendo, porque eles tão seguros daquela estrutura, agora se você vai aumenta o seu vocabulário, o porque daquele fim eles não tem segurança e também já ficam com medo de falar. Mas quando você trabalha a estrutura e você cobra ali, eu consigo sim. No $1^{\circ}$ ano eu pergunto só coisas simples, não consigo aumentar mais. Claro que tem salas grandes onde eu consigo pega uns 10, mas aí tem uma aula sim que é gostosa, mas tem a questão da segurança deles também, se eu pergunto alguma coisa do tipo "What kind of..." eles conseguem responde, mas eu ainda acho muito simples. (grifos do pesquisador)

Os três excertos foram unânimes em reportar à dificuldade de se trabalhar a oralidade. A professora 2 apontou o medo como problema principal. Quando abordada de maneira gradativa e estruturada, segundo a professora, há mais participação. A professora 1, por outro lado, destacou que a participação maior acontece nas series iniciais e levanta um fato importante com relação à comparação com as outras disciplinas. A cultura escolar parece não favorecer o desenvolvimento da habilidade oral, tanto auditiva quanto de fala. Assim, a habilidade de escrita é vista como conteúdo.

Sobre esse aspecto, Gee (2011, p. 66) utiliza o termo 'content literacy.' Segundo o autor, o conteúdo é identificado em rótulos como álgebra, biologia, literatura, cujo conhecimento foi produzido com o passar dos anos e foram sancionados e comodificados em livros. Assim, interpreto que no contexto investigado, a cultura grafocêntrica ainda era a única valorizada. Parece haver um conflito entre as culturas tipográficas e pós-tipográficas. Os adolescentes estariam na segunda, mas a escola parece predominar a primeira. 
A partir dessas colocações, direcionei a discussão sobre qual seria então a função do inglês como componente curricular, conforme o excerto abaixo.

P: A professora 1 falou da questão da matemática ou das outras na questão da escrita, não importa a área do conhecimento. E o que vocês acham então que é o papel do inglês na grade comparado com as outras disciplinas? a matemática tem uma função, a geografia tem uma função. Enfim, por certo motivo elas entraram na grade curricular como um conhecimento a ser trabalhado. Então [...] comparando o inglês que nós temos aqui, o que justifica [...] porque vocês acham que tem o inglês na grade da escola, será que é o mesmo inglês do curso de línguas ou será que é uma coisa diferente? Qual a função do inglês na escola?

P3: Eu acredito que o inglês seja para se ter um conhecimento cultural, um conhecimento cultural extra, um conhecimento cultural a mais, até mesmo para haver a comunicação. O inglês é colocado como uma língua que está se globalizando, não está totalmente ainda, mas já é bem maior de todas as línguas, e o que é interessante é eles saberem essa cultura, saberem essa história, essa diversidade que existe. (grifos do pesquisador)

O relato da professora se enquadra no argumento que Saxena e Omonniyi (2010) chamam de hiperglobalista. O posicionamento da Professora 3 de que, em um mundo globalizado, o conhecimento cultural, a facilidade de comunicação e a supervalorização de uma língua perante outra são utilizados para justificar o inglês em uma sociedade que está cada vez mais globalizada. O argumento principal é de que o inglês representa o status de uma língua dominante na escala global, reestruturando as interações e que a estrutura centro-periferia não existe mais. 
Da mesma forma, Georvieva (2010, p. 113) aponta que esse discurso coloca o inglês como "uma característica chave da nova ordem econômica e político-social mundial, tanto como meio e produtor de novas formas de interdependências, um produto e um promotor de globalização." Isso possui implicações, como por exemplo, nas tensões sobre as destruições de línguas menores, conforme apontado por Phillipson (1992). Essa questão também é abordada pela professora 3 ao mencionar 'bem maior que as outras línguas" e em relação ao 'conhecimento extra' como uma espécie de habilidade básica, conforme apontado por Graddol (2006).

A partir do depoimento da professora que salientava a questão cultural, levantei a seguinte colocação: Então aprender estaria mais relacionado a uma contribuição cultural?

P3: Eu acho, porque quando você sabe alguma coisa daquela cidade, algo cultural sobre aquela cidade e você vai lá ou alguém de lá vem até você, você tem um tratamento porque você já conhece, você já tem alguma informação [...] quando chega um estrangeiro ou quando vem um estrangeiro, um gringo né, que está falando a língua inglesa, para quem não tem um conhecimento cultural, não fala a língua inglesa, acaba tendo um medo de se comunicar. Eu acho que conforme vai, se ele fizer gestos, se ele fizer mímicas, fala uma palavrinha e tentar encaminhar outra ele vai consegui se comunicar, mas para isso ele precisa sentir a vontade. É preciso ter um pouquinho de conhecimento daquilo lá, e isso eu vejo, no fundo no fundo a gente não tem. (grifos do pesquisador)

A partir do depoimento da professora 3 , pode-se inferir que 0 aspecto cultural está relacionado a uma determinada cultura que se localiza em 
um determinado espaço geográfico, ao mencionar 'lá', o 'gringo', o 'estrangeiro'. Sobre essa questão, Pennycook (2010) argumenta que precisamos repensar a língua em relação aos imperativos pós-modernos, do que tratá-la dentro de uma territorialidade. Nessa perspectiva, o conceito de múltiplos tipos de língua inglesa pode ser mais adequado. Para tanto, há uma rearticulação para um novo sentido de história e localização, evitando-se assim, as narrativas de expansão e origem que a tradição tem disseminado. Assim, essa dicotomia do lá e aqui parece não fazer mais sentido, e surge o aspecto da simultaneidade e heterogeneidade. Além disso, mesmo que houvesse o conhecimento do lá e do aqui, como apontado pela professora, não há garantias de comunicação, conforme apontado pela professora 3. Neste sentido, parece-me que a negociação de sentido na comunicação intercultural seja mais significativa do que o conhecimento da cultura propriamente dito.

Os três excertos a seguir identificam os objetivos de se ensinar inglês na escola segunda uma ótica neoliberal.

P2: Quando eu comecei a dar aula eles me disseram que o inglês ele tem que sair falando e escrevendo igual em um curso de inglês. Essa era minha angústia quando eu comecei a dar aulas em uma escola regular porque eu achava isso também, eu pensava, se eu estou na disciplina de inglês e eu tenho essa competência eu tenho que passar essa habilidade para os alunos e eles tem que demonstrar resultados, e isso foi me trazendo muita angústia, aí eu comecei a ler um pouco mais e ver qual é o real objetivo da escola. É gerar a sociedade um pouquinho também, porque é como você falou, é uma outra realidade. Aí eu acho que a gente tem que trabalhar mais com esses objetivos, com a comunidade, com os alunos, porque senão a cobrança é muita, enfim, o aluno realmente não vai saí falando e escrevendo só vai ter algumas noções [...] é trabalhar os 
outros temas, sexualidade. O inglês não está isolado, ele está num contexto.

P3: Hoje eu até coloquei para os meus alunos essa história do porque aprende inglês. A maioria fala assim: "só para aprender outra língua", a maioria responde isso né, daí você explicar que não né, que quando você aprende outra língua o mundo abre para você né. Constantemente a televisão vem mostrando várias entrevistas de personalidades estrangeiras, a Globo News mesmo é uma que tem, o GNT tem, então é muito bom. (grifos do pesquisador)

A primeira narrativa demonstra que a professora 2 relata que, no início de sua carreira, seu objetivo de ensinar inglês na escola regular era o mesmo do curso de línguas. A professora também relata sua angústia em obter resultados. Esta primeira colocação pode refletir uma formação inicial que manifestou características de concepções neoliberais e pensamento instrumental, conforme apontado por Hoveid e Hoveid (2008). Essa perspectiva de educação voltada para resultados está relacionada à qualidade na educação que é acompanhada de medidas com foco em habilidades, que são testadas e enfatizam objetivos e resultados. Contudo, o local foi determinante para a professora rever seus objetivos. O conhecimento da formação inicial começou a ser redefinido em função da resposta dos alunos e das leituras feitas pela professora e, segundo o relato, começaram a repensar questões mais locais para os alunos.

A narrativa apresentada pela professora 3 representa uma visão neoliberal associada ao discurso da globalização. Conforme Omoniyi e Saxena (2010, p. 214), a visão pró-globalização e sua tendência progressista estão "em consonância com o argumento da agenda capitalista". Essa tendência associa 
a globalização à expansão de mercado, à competição, ao livre mercado e à democracia ocidental. Essa perspectiva também é denominada de 'hiper globalista' pelos autores. Assim, saber inglês estaria ligado a possibilidade de se ter as portas do mundo abertas, como uma atividade individual de sucesso.

Após a considerações sobre mídias e acesso ao inglês fora da sala de aula, questiono a professora 3 sobre o acesso dos alunos ao que ela explica.

Não, isso eu não coloquei para eles né, isso é na minha concepção. É muito bom você estar lá, esses dias eu estava passando roupa com a TV ligada e tinha uma entrevista lá na Globo News era com uma pessoa falando inglês. E você não precisa ficar olhando lá na tela, basta ouvir e você já está entendendo o que o cara está falando. Para eles é diferente, alguns até tem a TV à cabo, outros não, mas além disso, internet hoje em dia o adolescente é movido $100 \%$ à internet né. Em toda parte que você vai, tudo lá está escrito em inglês, raramente você vê comandos em português. Aí hoje eu escrevi lá, escreva 5 palavras que você já conheça na língua inglesa, um aluno me escreveu 5 e eu perguntei onde ele tinha aprendido, e ele respondeu que jogando vídeo game, então quer dizer, eles estão em contato com essa língua, mas eles não percebem. Então isso que a gente precisa enfiar na cabeça deles, eles estão isolados. E outro motivo pelo qual eles questionam o porque de aprende inglês, eles dizem que não vão para fora, não vão para o exterior. Gente, não é por aí, eu tento coloca na cabeça deles, hoje em dia no mercado de trabalho um dos requisitos é você aprender uma língua. $A$ veja está mostrando vários sites de reportagem [...] tem vários textos que discutem a importância do inglês no mercado de trabalho. Vários concursos hoje em dia já pedem o básico do curso de inglês, [...], então é assim, não está à tão na escola. 
P2: A diferença que a gente vê é que eles não têm um objetivo, não tem um sonho, diferente dos alunos da escola particular que já vem se preparando pro vestibular e aqui não, eles estão parados naquele mundo do EM. Eles falam que não têm condições de passar na Federal, porque não tem condições de paga uma escola particular, então pra eles o vestibular não é foco. Eles dizem que o material lá é melhor, que os professores são melhores, mas os mesmos professores que trabalham lá trabalham aqui. (grifos do pesquisador)

No primeiro excerto, a professora 3 aponta a importância da mídia de massa como a internet e a televisão na aprendizagem do aluno, revelando certa dificuldade em demonstrar para o aluno o objetivo de se aprender inglês. O relato também aponta a interferência das revistas na relação aprender inglês e mercado do trabalho. A professora 2 demonstra a falta de perspectiva dos alunos sobre prestar uma prova de vestibular. As duas narrativas convergem para o aspecto da aprendizagem da língua inglesa e a relação desta no mundo do trabalho e dos estudos, como uma maneira de encontrar o sucesso profissional.

Os relatos refletem o que Lankshear (2007, p. 317) chama de a concepção liberal sobre pessoas e sociedade em que a educação valoriza a “individualização e comodificação de língua e letramento." Nessa perspectiva, a sociedade é composta de pessoas livres, iguais; o sucesso e a liberdade são produtos das suas próprias iniciativas. O letramento é comodificado, marcado por agenda de reforma que valoriza testes, validação de conhecimento, perfis, diretrizes curriculares para assegurar o resultado exigido.

Até o momento dessa discussão, as narrativas demonstram que o ensino de língua inglesa na escola investigada reflete tendência de 
representação de um modelo neoliberal da globalização sobre a função de se aprender inglês. Pode-se inferir ainda, uma visão colonial nos relatos das professoras com relação a segunda língua e cultura. As professoras demonstram desconforto em se trabalhar com salas heterogêneas, bem como a desmotivação dos alunos nas atividades propostas. Com relação à visão sobre educação, não há associação com temas que abordem o contexto local. Evidenciou-se, a partir dos relatos, que as professoras parecem valorizar mais o contexto privado em comparação com o contexto público.

Feitas tais considerações, no próximo capítulo busco investigar se há discrepâncias entre os dois documentos oficiais para o ensino da língua inglesa no segmento do ensino médio (nacional e estadual); verificar quais os conflitos que podem emergir quando se tem dois documentos voltados para 0 mesmo segmento, e ainda, verificar o que contribui para o professor ter 0 sentimento de posse ou rejeição aos documentos e, por fim, discutir o aspecto de 'emancipação' e sujetificação na formação de professores via documentos oficiais. 


\title{
CAPÍTULO III
}

\section{SERÁ QUE EU SEI O QUE É BOM PARA VOCÊำ NEGOCIANDO E (RE)CONSTRUINDO POLÍTICAS LINGUÍSTICAS E CONHECIMENTOS LOCAIS}

\begin{abstract}
P: [...] ou às vezes acontecia o contrário [...] eu sugeria um texto ou levantava algumas questões e elas falavam: Ah!Tá interessante! [...] com toda a polidez [...] A P1 principalmente. (risos). O texto é interessante, mas você não acha que talvez pra esse contexto aqui poderia ser [...] adaptado?". Isso acontecia muito [...] Então, eu propunha uma ideia, a sugestão era renegociada [...] porque eu tenho uma visão de fora, eu posso sugerir algumas questões, mas é o local que atribui sentido ${ }^{13}$.

P2: É porque a realidade de nossos alunos não é a mesma dos alunos de São Paulo, do Rio, enfim, a gente tem que trazer para nosso local, não é? Você tem que pensar no seu aluno que tá ali diante de você. Vamos trazer do global, nacional e local. Aí você contextualiza para o seu aluno, porque não adianta você pegar uma coisa que aconteceu [...] o que isso vai acrescentar para o nosso aluno? Não é melhor você trabalhar a cultura dele $[\ldots]$ ?
\end{abstract}

O título deste capítulo e os dois excertos acima podem servir de ponto de partida para se problematizar o processo tradicional de emancipação

\footnotetext{
12 "Eu sei o que é bom para você" foi uma expressão que ouvi do Prof. Dr. Lynn Mario Trindade Menezes de Souza ao questionar o posicionamento de quem emancipa quem, durante as aulas da disciplina: narrativas e identidades.

${ }^{13}$ Excerto extraído de uma palestra proferida por este pesquisador juntamente com as professoras 1 e 2 para professores da escola pública e acadêmicos do curso de Letras da UFMS, a convite da Profa. Dra. Nara Hiroko Takaki.
} 
que estabelece uma lógica de desigualdade entre o emancipador e o emancipado na formação de professores. Essa visão coloca o pesquisador em uma posição superior ao sujeito a ser emancipado [professor]. Para que a emancipação possa acontecer, o emancipado precisa ser submetido ao conhecimento do emancipador. A outra perspectiva que proponho neste trabalho parte de uma lógica horizontal que coloca tanto o pesquisador quanto o professor colaborador em posições hierárquicas não tradicionais, conforme discuto mais adiante.

Ao me referir a (re)construir ${ }^{14}$ políticas linguísticas e conhecimentos locais no título deste capítulo, tomo como base a discussão de dois documentos oficiais que oportunizam tanto este pesquisador quanto as professoras colaboradoras a olhar para a prática retomando o conceito de letramento crítico das políticas linguísticas (ressignificando Freire, 1996, 2005; Menezes de Souza, 2011), conforme abordado no capítulo anterior. Neste, amplio a discussão com base em Monte Mór (2011, 2012). Posiciono-me ainda, sobre o conceito de conhecimento local e sua interface com a formação de professores via documentos oficiais.

Para direcionar o enfoque nesta parte final do trabalho, proponho o seguinte questionamento:

\footnotetext{
${ }^{14} \mathrm{O}$ termo reconstruir também foi usado por Zakharia (2010, p. 162) - (re)constructing language policy in a Shi'i school in Lebanon - como analogia à postura de como os professores rejeitam as associações coloniais das línguas estrangeiras, isolando as de sua origem e então por meio de um processo pedagógico gerativo, reconstroem as línguas com o local, contemplando as preocupações que buscam destacar a comunidade e o mundo real. Ao mesmo tempo, as práticas pedagógicas e sociais da reconstrução possibilitam que os professores engajem os alunos para que possam cumprir os padrões educacionais exigidos pelo governo e, ao mesmo tempo, dá atenção às necessidades dos alunos em contextos de comunidades historicamente marginalizadas.
} 
De que maneira o conhecimento local pode ser reconstruído a partir da colaboração na implementação de documentos oficiais?

A partir dessa pergunta, delimito a análise com duas outras subperguntas:

1) Os documentos oficiais representam uma orientação para o ensino de língua inglesa do ponto de vista das professoras participantes?

Busco com essa indagação enfocar dois aspectos: Primeiro, investigar se há discrepâncias entre os dois documentos oficiais para o ensino da língua inglesa no segmento do ensino médio (estadual e federal); segundo: verificar quais conflitos podem emergir quando se tem dois documentos voltados para o mesmo segmento.

2) De que maneira as propostas curriculares são interpretadas, negociadas, contestadas e (re)criadas na sala de aula?

Com essa pergunta, busco verificar o que pode levar as professoras a adotar ou se distanciar de tais orientações.

Antes de buscar responder a pergunta de pesquisa deste capítulo, situo o leitor em relação aos dois documentos oficiais que nortearam as discussões dos encontros com as professoras participantes da pesquisa: 0 Referencial para o Ensino de Língua Inglesa do Estado de Mato Grosso do Sul (2008) e, em seguida, as Orientações Curriculares para o Ensino Médio Língua Inglesa (2006) propostas pelo Ministério da Educação. Para descrever o primeiro, faço uma adaptação de duas categorias apresentadas por Rizvi e Lingard (2010). Os autores propõem três critérios para a análise das políticas linguísticas: questões contextuais; questões políticas e textuais; questões de implementação e resultados. 
A primeira refere-se às questões contextuais que descrevem as origens, as razão e a relação com possíveis propostas anteriores, bem como 0 papel dos principais stakeholders envolvidos no estabelecimento de uma agenda política. A segunda remete-se às questões políticas e textuais. Nela, os aspectos discursivos da política são evidenciados. A última [questões de implementação e resultados] não será utilizada considerando-se que não busco mensurar os resultados. Em seguida, descrevo de maneira geral as Orientações Curriculares para o Ensino Médio.

\subsubsection{Referencial Curricular para o Ensino Médio: Língua Inglesa - Estado de Mato Grosso do Sul}

O Referencial Curricular para o Ensino Médio - Língua Inglesa - para - Estado de Mato Grosso do Sul foi lançado em 2008, precedido por outros dois documentos voltados para o mesmo segmento nos anos de 2004 (estadual) e 2006 (federal). Apesar dos documentos terem sido lançados em um curto espaço de tempo entre as duas últimas propostas, o referencial de Mato Grosso do Sul de 2008 não possui um aspecto de continuidade com o documento oficial do Estado lançado no ano de 2004. Esta proposta para o ensino de inglês foi pautada no ensino das obras clássicas da literatura inglesa conforme uma visão modernista de língua e cultura (Mato Grosso do Sul, 2004). O documento de 2008, por outro lado, priorizou um conjunto de competências e habilidades, seguido de uma lista de conteúdos gramaticais e lexicais. Desta maneira, nenhum dos dois documentos estaduais possui características de convergência com as Orientações Curriculares para o Ensino Médio (OCEM, 2006). O Referencial Curricular para o Estado de Mato Grosso 
do Sul foi elaborado sob a autoria de técnicos da Secretaria Estadual de Educação de MS. A estrutura do documento foi a mesma para todas as disciplinas, obedecendo a um design que contemplou listas de competências e habilidades, seguidas de um lista de conteúdos estruturais apresentados de forma gradativa distribuída em quatro bimestres (ver anexo 1).

Durante o processo de planejamento do documento, várias escolas foram consultadas como pareceristas do referencial estadual. No entanto, os relatos das professoras participantes dessa pesquisa, bem como as assembleias da Associação de Professores de Inglês do Estado de Mato Grosso do Sul apontam que as observações feitas pelos professores não foram levadas em consideração pelos técnicos da Secretaria Estadual de Educação uma vez que, segundo as professores, não houve alterações textuais no documento.

P2: Na verdade eles pediram para que cada escola pegasse 0 antigo e colocasse alguma alteração e nós fizemos isso. Eu acho que não chegou porque da maneira que veio. Não que teria que ser como nós fizemos, mas eu acho que veio totalmente sem coerência entre as competências e os conteúdos.

P1: Só que o que está no papel não está na prática, porque eles só listaram tópicos. Eu acho que eles têm que se preocupar é em transformar o profissional dando condições, fazer com que o profissional tenha condições de transformar esses tópicos em realmente situações reais que você realmente dê em uma aula.

P3: Só que eles realmente jogaram a bomba nas mãos dos professores. Porque nós nos reunimos em 2007, cada escola se reuniu por área e montou um referencial curricular da escola, ai foi mandado tudo para a secretaria, compilado, selecionado e feito isso aqui. Então a bomba foi jogada para as mãos dos professores eles selecionaram os tópicos 
P2: Mas na verdade eles mandaram essa cópia pra gente mudar não foi?

P1: Nós mudamos, só que voltou da mesma forma, não mudou. Só o que nós montamos tinha metodologia de ensino, tinha objetivo do ensino da disciplina, tinha forma de avaliação. Não foi esse referencial que eles escreveram e depois jogaram toda a responsabilidade sobre os professores.

O Referencial Curricular para o Ensino Médio direcionado à disciplina de língua inglesa do Estado de Mato Grosso do Sul surge na esteira de outros documentos lançados nacionalmente, em um processo de reestruturação das políticas educacionais como, por exemplo, os PCN, as OCEM, entre outros documentos.

Com relação à questão textual do documento, destaco dois aspectos importantes na apresentação do documento: os aspectos teóricos que buscam embasar academicamente o documento e o aspecto ideológico subjacente ao texto. Para ilustrar essa questão, tomo como base as três seções do documento: primeiro, o texto introdutório que apresenta uma lista de competências e habilidades; em seguida, a distribuição dos conteúdos feita em forma de uma lista de itens gramaticais e lexicais alocadas por bimestre e, por último, as referências bibliográficas que são contempladas.

No texto das competências e habilidades, os aspectos teóricos presentes nos objetivos transparecem as visões da pragmática, da linguística textual, da competência comunicativa e da gramática normativa, que se chocam teoricamente ao se considerar os seguintes excertos: Pragmática Contexto da interlocução, reconhecer os recursos expressivos; Estudos Culturais - Emitir juízo crítico de valores sobre diferentes culturas; Gramática normativa - Correta, norma culta, apropriados; Linguística funcionalista - 
Usuários, interlocutores, interlocução, ser capaz de compreender, para dizer enunciados corretos; Linguística textual - Textos coesos e coerentes.

Os objetivos apresentam inconsistências de conceituação de nomenclaturas teóricas, tais como: norma culta e linguagem informal, ao invés de norma culta e coloquial. Apresenta também incoerência em: produzir enunciados corretos e apropriados que parece referir-se à gramática normativa e ao mesmo tempo sugere o uso de competências, como por exemplo, a competência sociolinguística. Neste caso, abarca as outras variantes e não apenas a legitimada como "correta", porém outras apropriadas ao contexto de fala.

No que se refere ao aspecto lexical, o referencial sugere o seguinte procedimento: selecionar o vocabulário adequado para o uso oral e escrito [...] que se amplia ao longo dos três anos. No entanto, o referencial elenca, ao longo dos quatro bimestres, vocabulários e temas que contemplam listas como alfabeto, números, partes do corpo, estações do ano, cores (ver anexo 1), entre outros, de forma isolada. Esses itens não condizem com a faixa etária dos alunos do ensino médio, principalmente no que tange ao desenvolvimento do aspecto crítico, conforme apontado na apresentação.

Apesar de a palavra contexto chamar atenção no referencial pela recorrência na lista das competências e habilidades, como por exemplo, contexto de interlocução; apropriados aos seus contextos de língua; textos e seus contextos, contexto comunicativo, há uma discrepância com a forma como são apresentados. A lista de conteúdos é contemplada de forma descontextualizada e gradativa, por meio de itens gramaticais e lexicais, divididos bimestralmente. Além disso, a sugestão sobre compreensão textual 
apenas é indicada no primeiro semestre do segundo ano, embora haja indicação do desenvolvimento de competências e habilidades ao longo dos três anos, ao se referir: interpretar no contexto da interlocução, relacionar textos e seus contextos, perceber o texto como um todo coeso e coerente.

Ao analisar as sugestões teóricas nas referências bibliográficas, o professor não encontrará o suporte teórico apontado nas competências e habilidades. Para exemplificar essa afirmação, as indicações foram agrupadas de acordo com a temática. São elas: 04 sugestões de leitura sobre competências do professor; 01 indicação de parâmetro oficial, que se refere ao PCNEM-LE de 1999, sendo que dois outros documentos oficiais, posteriores a este foram publicados em 2001 e 2006. Não há referência a nenhum documento estadual anterior; 05 indicações sobre metodologia de ensino de língua inglesa no que se refere ao início da abordagem comunicativa nos anos de 1979, 1981, 1982, 1984, mostrando-se, assim, não atualizado com as principais tendências contemporâneas; 01 indicação de livro de metodologia científica que não é o foco de nenhuma discussão do documento; 01 indicação de literatura inglesa do ano de 1974; 02 referências sobre leitura que abordam aspectos cognitivos e não discursivos como presente nas referências; 04 indicações de livros sobre pedagogia; 03 indicações escritas em língua francesa sobre metodologia e psicologia.

Além dessas indicações listadas acima, que demonstram a ausência de subsídios teórico-metodológicos como insumo para que o professor pesquise ou expanda o seu conhecimento sobre as nomenclaturas presentes na seção das habilidades e competências, destaco duas indicações que chamam atenção, pelo total descompasso com o suporte teórico para a 
formação de professores, bem como para fundamentação do processo de ensino-aprendizagem de língua inglesa:

MENDELSOHN, Patrick. Suplemento de informática de L`Hebdo. Dezembro de 2007, p. 12.

Oficina criativa e análise microgenética de um projeto de modelagem em argila. Instituto de Psicologia da USP, 2000. Tese de dourado apresentada ao IPUSP, sob a orientação do Prof. Dr. Lino de Macedo.

Assim, interpreto que o eixo de teoria apresenta-se fragmentado. Identifico apenas estratégias de preenchimento com indicação de algumas expressões-chave por meio das quais o leitor pode inferir algumas correntes teóricas da linguística. Contudo, estas são incoerentes com a organização dos conteúdos do currículo que está contemplada de forma estrutural. O contrassenso também se estende às sugestões de leitura apresentadas nas referências bibliográficas, conforme pode ser observado no quadro a seguir.

\begin{tabular}{|l|l|}
\hline Competências e habilidades & Conteúdos linguísticos \\
\hline - Identificar manifestações culturais no eixo & $\mathbf{1}$ o BIMESTRE \\
temporal, reconhecendo momentos de tradição & Personal pronouns, \\
e de ruptura; & Verb to be - (all forms); \\
- Emitir juízo crítico sobre as manifestações & Short answers; \\
culturais; & There is/There are; \\
- Analisar metalinguisticamente as diversas & Demonstratives: \\
linguagens; & This/That, these/those; \\
- Ser capaz de compreender e produzir & Definite and indefinite articles; \\
enunciados corretos e apropriados a seus & Interrogative words: who, where, \\
contextos em língua estrangeira, fazendo uso & what, how; \\
de competências gramaticais, estratégicas, & Simple Present - 3 forms; \\
sociolinguísticas e discursivas; & Present continuous - 3 forms. \\
- Saber distinguir norma culta de linguagem & \\
\hline
\end{tabular}




\begin{tabular}{|c|c|}
\hline $\begin{array}{l}\text { informal e, especialmente, os contextos de uso } \\
\text { em que uma e outra devem ser empregadas. o } \\
\text { uso de gírias é apropriado, desde que o } \\
\text { contexto assim o permita. É importante, pois, } \\
\text { selecionar vocabulário adequado para o uso } \\
\text { oral e escrito, a partir de um repertório que se } \\
\text { amplia gradualmente ao longo de três anos } \\
\text { de curso; } \\
\text { - Relacionar textos e seus contextos por meio } \\
\text { da análise dos recursos expressivos da } \\
\text { linguagem verbal, segundo intenção, época, } \\
\text { local e estatuto dos interlocutores, fatores de } \\
\text { intertextualidade e tecnologias disponíveis; } \\
\text { - Perceber o texto como um todo coeso e } \\
\text { coerente, no qual certas expressões e } \\
\text { vocábulos são empregados em razão de } \\
\text { aspectos socioculturais inerentes à ideia que } \\
\text { se quer comunicar. }\end{array}$ & $\begin{array}{l}2^{\circ} \text { BIMESTRE } \\
\text { Simple present - Verbs } \\
\text { Do/does/don't/doesn't; verb to } \\
\text { have: } \\
\text { present - affirmative; } \\
\text { Possessive adjectives; } \\
\text { Prepositions and adverbs of place. } \\
\text { 3o BIMESTRE } \\
\text { Plural of nouns; } \\
\text { Possessive case of nouns: } \\
\text { Whose...? } \\
\text { Imperative; } \\
\text { Adverbs of frequency. } \\
\text { 4o BIMESTRE } \\
\text { Verbs: like, need, want }+ \text { infinitive; } \\
\text { Modals: can/may; } \\
\text { Object pronouns. }\end{array}$ \\
\hline Cor & $\begin{array}{l}\text { Jgestões } \\
\text { úmeros) }\end{array}$ \\
\hline $\begin{array}{l}\text { Durante os } 4 \text { bimestres serão trabalhados os } \\
\text { seguintes temas e vocabulários: } \\
\text { The alphabet, music, Greetings, introductions, } \\
\text { countries, nationalities, jobs or professions, } \\
\text { cardinal and ordinal numbers, days of the week, } \\
\text { months of the year, seasons of the year, ages, } \\
\text { dates, addresses, hours, family, objects, } \\
\text { clothes, colours, foods and drinks, sports, } \\
\text { subjects, parts of the house, parts of the human } \\
\text { body, likes and dislikes }\end{array}$ & $\begin{array}{l}\text { 04= sugestões de leitura sobre } \\
\text { competências do professor; } \\
01=\text { PCNEM de 1999; } \\
05=\text { abordagem comunicativa nos } \\
\text { anos de 1979,1981,1982, 1984; } \\
01=\text { metodologia científica; } \\
01=\text { literatura inglesa do ano de } \\
1974 ; \\
02=\text { aspectos cognitivos de leitura; } \\
04=\text { pedagogia; } \\
03=\text { em língua francesa sobre } \\
\text { metodologia e psicologia }\end{array}$ \\
\hline
\end{tabular}


Quadro 1: Excertos do Referencial Curricular para o Ensino Médio - Língua Inglesa Primeiro ano. (grifos do pesquisador)

Sobre a função do documento, embora o objetivo principal desse gênero seja orientar o professor e se manter atualizado com as correntes teóricas, posso inferir que há alguns excertos que tentam se aproximar de forma superficial listando apenas algumas frases que poderiam se originar dos estudos linguísticos, na linguística aplicada, nos estudos da linguagem e nos estudos culturais.

Não há no documento a preocupação com questões globais, ideológicas, culturais ou identitárias relacionadas com a língua, bem como o seu papel como disciplina formadora do currículo. Observo, ainda, a ausência de discussão sobre as novas linguagens digitais que têm sido foco de documentos oficiais que se preocupam com as novas formas de representação de sentido no contexto digital. A seguir descrevo o documento lançado pelo Ministério da Educação para o ensino da língua inglesa para o Ensino Médio.

\subsubsection{Orientações Curriculares para o Ensino Médio: língua Inglesa (MEC)}

As Orientações Curriculares para o Ensino Médio (OCEM) foram lançadas no ano de 2006, cinco anos após a versão dos Parâmetros Curriculares para o Ensino Médio + (PCNEM +), precedido dos Parâmetros Curriculares para o Ensino Médio (PCNEM) em 1999, tendo sido este último publicado um ano após os PCN do Ensino Fundamental (1998).

As OCEM, língua inglesa, salientam que as concepções de linguagem, cultura e conhecimento devam ser trabalhadas como totalidades 
abstratas. Para os autores desse documento, tais concepções deveriam basear-se em uma visão heterogênea, plural e complexa de linguagem, de cultura e de conhecimento, inserida nos contextos socioculturais, interagindo com novos insumos, podendo gerar transformações de forma crítica e eficaz. A concepção de heterogeneidade presente no conceito de letramentos visa à formação de um aprendiz capaz de compartilhar, recriar, recontextualizar e transformar, e não apenas reproduzir conhecimentos estanques. Além disso, os letramentos para a sociedade atual devem visar à preparação dos alunos para o futuro desconhecido, para agir em situações novas imprevisíveis e incertas (OCEM, 2006).

Essas orientações foram elaboradas com base nas teorias dos novos letramentos (LANKSHEAR E KNOBEL, 2003; SNYDER, 2001; GEE, 2001), multiletramentos (COPE E KALANTZIS, 2000) e letramentos críticos (LUKE E FEEBODY, 1997). A proposta sugere a reinterpretação do papel da língua inglesa no currículo escolar, com os objetivos de: discutir o papel e a importância do ensino de línguas estrangeiras para o ensino médio; apresentar as questões de inclusão e exclusão na educação, baseado na noção dos valores globais e a interface com o ensino de língua inglesa; introduzir as novas teorias de linguagem e novas tecnologias (letramentos, multiletramentos, multimodalidade e hipermodalidade) e oferecer sugestões sobre as práticas de ensino e aprendizagem de línguas estrangeiras baseadas em tais teorias.

O documento ressalta, ainda, a leitura, a escrita e a fala de uma maneira contextualizada. Contudo, as orientações não representam o renascimento da abordagem comunicativa e não são prescritivas como um currículo tradicional. Portanto, os autores propõem uma mudança de uma visão 
instrumental do ensino de línguas para uma proposta educacional de desenvolvimento de cidadãos críticos por meio das línguas estrangeiras, conforme apontado por Monte Mór (2009).

Para que as sugestões apresentadas nas OCEM possam fazer sentido para os diferentes contextos brasileiros, os autores sugerem que sejam reinterpretadas conforme o contexto local. A razão para tal se deve à percepção de que, o conhecimento e as práticas locais têm sido silenciados ou até mesmo marginalizados nos contextos tradicionais de formação de professores. Neste sentido, discuto a seguir a implicação do conhecimento local para o processo de formação de professores.

\subsection{0 conhecimento local}

Durante muito tempo, uma das questões que tem norteado a discussão no âmbito educacional tem sido compreender que tipo de conhecimento deveria ser valorizado na escola. Já nas últimas quatro décadas, de acordo com Apple (2010), essa afirmação tem tomado outro enfoque. Ao invés de se buscar valorizar apenas um determinado conhecimento, a pergunta volta-se para uma reflexão sobre "o conhecimento de quem vale mais". Essa discussão pode abrir espaço para compreender as relações entre as políticas educacionais, o currículo, o ensino, a avaliação e suas relações de poder.

Os estudos sobre as perspectivas críticas, segundo Apple (2010), têm evidenciado relações sincrônicas e diacrônicas contraditórias, entre o conhecimento e o poder, entre o estado e a educação e entre a sociedade civil e o imaginário político. Para lidar com as complexidades na educação e para compreender a relação entre a legitimação de certo conhecimento como 
canônico e outros como marginalizados, os estudos, conforme Pennycook (2007), têm se voltado para as questões globais, para o imaginário colonial e para as abordagens pós-coloniais.

A legitimação de um conhecimento sobre outro é produzida por mecanismos de controle e procedimentos de exclusão. Neste sentido, Foucault (2009, p.8) aponta que "a produção do discurso é [...] controlada, selecionada, organizada e redistribuída por certo número de procedimentos que têm por função conjugar seus poderes e perigos, dominar seu acontecimento [...]". Associando-se essa afirmação ao fortalecimento de determinado conhecimento local, a legitimação pode acontecer, conforme o referido autor, por um conjunto de práticas que reforça e valoriza um determinado saber para a sociedade por meio da pedagogia.

Como resultado, em várias esferas sociais, conforme descrito por Canagarajah (2002), o conhecimento local é tratado como exótico, sabedoria popular, paroquial, saber irracional e de menos prestígio, comparado com o conhecimento científico. No entanto, todo conhecimento pode ser considerado local e, portanto, específico a uma comunidade. O que o legitima, segundo a visão modernista, é sua relação com a economia mundial que estabelece a geopolítica dos que possuem mais ou menos prestígio, bem como a sua evolução em relação ao progresso.

As políticas públicas educacionais também frequentemente reforçam a visão de progresso e, mais recentemente, são influenciadas pelo discurso da globalização. Sobre esse aspecto, Hoveid e Hoveid (2008, p. 127) criticam que "os conceitos neoliberais e o pensamento instrumental defendem que a qualidade na educação seja concebida como algo a ser garantida pela 
avaliação dos alunos em testes pautados em habilidades, com ênfase em objetivos e resultados". Essa visão tende a reduzir a educação a algo que valoriza as soluções técnicas, tanto na educação básica, quanto no ensino superior.

Apesar de todo o movimento para desvalorizar o conhecimento local, os trabalhos dos pós-modernistas, pós-estruturalistas e pós-colonialistas têm despertado o interesse em valorizar o conhecimento local de forma crítica. Sobre as investigações realizadas, Canagarajah (2002) aponta quatro diferentes correntes nos estudos culturais e pós-colonialistas.

A primeira refere-se ao campo da sociologia. Essa perspectiva explora o conhecimento que emerge da prática de uma determinada comunidade ao longo de sua história. A segunda preocupa-se com o sentido social. Evidenciam-se, nesses estudos, as outras práticas que diferem do conhecimento oficial nas várias instituições, como nos contextos legal, fiscal e político. A terceira reporta o contexto acadêmico, no qual o conhecimento local diverge do conhecimento canônico, mas que, no entanto, coexiste nas esferas sociais. O último se detém ao sentido profissional e refere-se ao conhecimento não reconhecido pelas autoridades das áreas profissionais.

Os quatros enfoques para o estudo do conhecimento local convergem conceitualmente, segundo Canagarajah (2005), no que se refere ao conhecimento local como contextual. Assim, o conhecimento local é especifico à comunidade, é fluido e relacional, bem como é gerado nas práticas sociais do dia a dia.

Para explorar o aspecto local no contexto linguístico, Canagarajah (2009) sugere que a pesquisa utilize uma orientação etnográfica. Essa 
característica metodológica, segundo o autor, pode levantar informações sobre como a língua é praticada em contextos localizados. O enfoque investigativo desse trabalho não busca descobrir novas formas de linguagem e representações como têm sido realizados em alguns trabalhos etnográficos (Street, 2007; Barton e Hamilton, 1998, Menezes de Souza, 2007).

Conforme discutido por Canagarajah (2002, 2005), o conhecimento local deve ser reinterpretado. Nessa perspectiva, os conhecimentos locais das professoras, bem como do pesquisador, podem ser reconstruídos, a partir de um processo de reinterpretação crítica com relação às suas concepções teóricas sobre o ensino da língua inglesa. Para tanto, aproprio-me desse conceito e o reinterpreto para o estudo das políticas linguísticas e para a formação de professores. Canagarajah $(2002,2005,2009)$ também considera o conhecimento local como algo que está em constante mutação e, desta maneira, que pode ser repensado, desinventado e reconstruído. Essas considerações se assemelham às discussões sobre políticas linguísticas, apresentadas por McCarthy (2011).

Para a autora, a política linguística deveria ser vista de forma processual, dinâmica e em movimento. Assim, McCarthy (op.cit., p. 2) aponta que o estudo das políticas linguísticas "não se restringe à análise das declarações e textos [...] mas deve ser visto como parte de um sistema sociocultural maior." Ressignificando essa afirmação para a pesquisa em questão, investigar as práticas das professoras, a partir do estudo dos documentos oficiais constitui aspecto mais importante do que o estudo exclusivo na análise documental. Assim, a ênfase é dada na prática da localização, que segundo Canagarajah (2002), representa um projeto 
desconstrutivo e reconstrutivo em que um informa o outro. Para tanto, o autor propõe um compromisso contínuo que envolve desconstruir o conhecimento dominante e compreender como esse molda nossas práticas locais. Em outras palavras, isso implica em uma atividade reconstrutiva que envolve reinterpretar o conhecimento estabelecido para os interesses locais.

Além disso, o autor argumenta que o conhecimento local não se limita a localidade, mas possui o compromisso com a consciência da própria localização para o engajamento com o conhecimento de outras localizações na medida em que são desconstruídas para os próprios propósitos. Portanto, não se trata da visão binária local global, tampouco do conceito de glocal, que remete ao global no local. O termo translocal traduz melhor a discussão, conforme discutido no capítulo I, associado ao debate sobre a geopolítica da língua inglesa.

Assim, diferentemente da padronização, Norton (2010, p. 192) aponta a importância do aspecto de uma educação linguística local que leve em consideração o desenvolvimento do aspecto identitário no aluno e no professor. A autora afirma que as pesquisas nessa temática têm contribuído para situar o aprendiz em "contextos sociais, históricos, político e cultural" e que a aprendizagem possa explorar as formas de negociações e resistências a eles impostas pela língua. A seguir, faço um levantamento introdutório sobre o foco da formação de professores do Brasil.

Feitas tais considerações, retomo as perguntas de pesquisa que busca investigar se há discrepâncias entre os dois documentos oficiais para o ensino da língua inglesa no segmento do ensino médio (nacional e estadual); verificar quais os conflitos que podem emergir quando se tem dois documentos 
voltados para o mesmo segmento, e ainda, verificar o que contribui para 0 professor ter o sentimento de posse ou rejeição aos documentos e, por fim, discutir o aspecto de emancipação e sujetificação na formação de professores via documentos oficiais.

\subsection{Será que eu ainda sei o que é bom pra você? A lógica de emancipação revisitada}

Ao abordar o tema criticidade, mais especificamente o aspecto do letramento crítico das políticas linguísticas e a formação de professores, um aspecto que considero importante diz respeito à emancipação, uma vez que ocupa posição central nas teorias e práticas modernas de educação.

Nesse sentido, retomo o conceito de emancipação que sinalizei no início deste capítulo para abordar alguns aspectos relacionados à formação de professores. Durante o processo colaborativo nessa pesquisa, os participantes assumiram papeis cuja lógica da emancipação não segue o percurso comumente descrito na formação crítica de professores, sob a influência da pedagogia crítica. Para fundamentar a discussão, exponho o conceito de emancipação e sua crítica com base em Rancière (2010). Em seguida, discuto a lógica emancipatória revisitada fundamentada em Biesta (2008, 2010, 2011). Para ilustrar os posicionamentos, apresento alguns dados coletados dos encontros com as professoras participantes, durante o processo colaborativo.

\subsubsection{Emancipação e formação crítica de professores}

Mas o que significa a palavra emancipar? De acordo com o wikidicionário, duas principais definições são apresentadas: 1. tornar-se independente; libertar-se (Ex. o feminismo veio emancipar a mulher - do jogo 
masculino); 2. eximir-se do pátrio (Ex. o juiz emancipou o jovem da tutela dos tios). Partindo-se do conceito literal da palavra, quais seriam então as implicações dessas duas definições para a formação de professores e para a relação professor-aluno? Nesses dois contextos, poderíamos questionar: Quem emancipa quem? Ou ainda, quem emacipa quem em relação a que $(\mathrm{m})$ ?

Em consonância com os dois significados acima, Rancière (2010, p.27) relata que o conceito de emancipação possui suas raízes na lei romana, referindo-se a "libertar um filho ou esposa da autoridade pater familias, o pai da família". Assim, o objeto da emancipação [sujeito a ser emancipado] torna-se livre como resultado do ato da emancipação. $O$ autor descreve como isso tem ocorrido no decorrer da história: no século XVII, a emancipação esteve relacionada à tolerância religiosa; no século seguinte, à libertação dos escravos; já no século XIX, à emancipação das mulheres e dos trabalhadores.

No século XVIII, em especial, a emancipação mostrou-se ligada ao iluminismo e, consequentemente, houve reflexo na educação, principalmente pela influência de Kant. Das contribuições desse filósofo, duas se destacam: a primeira está ligada à tese de que a prosperidade e a vocação humana para libertar o pensamento não eram uma possibilidade histórica contingente, mas deveria ser vista como uma parte herdada da natureza humana. A segunda considera que o ser humano só pode se tornar humano pela educação. Assim, o iluminismo era sinônimo de emancipação. Rancière (2010) alerta que essa visão, quando adotada por um sistema ideológico, pode levar a uma forma de nazismo ou fundamentalismo como resultado de uma conversão teórica. Esse tipo de pensamento também é criticado por Todd (2009) ao discutir o termo cosmopolitismo clássico e sua imagem do humanismo universalizado e 
idealizado que tenta apagar as diferenças. A autora vê a educação como uma oportunidade de pensarmos mais sobre a responsabilidade de nossas próprias respostas em relação ao outro.

Considerando-se a vertente da educação crítica, sob influência da teoria marxista ou neo-marxista, pode-se considerar que a emancipação se detém em analisar as estruturas opressivas, as suas práticas e as suas teorias. Segundo essa corrente teórica, "para nos libertarmos dos trabalhos do poder, precisamos expor como o poder opera em nossas consciências" (RANCIĖRE, 2010, p. 30). O emancipado, nessa perspectiva, é incapaz de compreender as ideologias, bem como de identificar como o poder opera através delas e, consequentemente, perceber como suas consciências são moldadas em função disso. Sobre esse preceito, Jordão (no prelo) faz uma distinção entre pedagogia crítica e letramento crítico. Convido o leitor a reinterpretar as duas citações abaixo, bem como ressignificá-las para a formação de professores, na qual o formador assume o papel de professor e o professor a de aluno.

$\mathrm{Na}$ pedagogia crítica, cabe à escola conhecer e ensinar o funcionamento da "ideologia", entendida como um véu que oculta à suposta realidade por trás dele, e assim libertar os alunos, oprimidos pelos mecanismos ideológicos (sob o pressuposto de que o professor já se "libertou" deles) (Jordão, no prelo)

No letramento crítico, as escolas deveriam se constituir em espaços para questionamento das práticas de construção de sentidos e representação de sujeitos e saberes, para problematização dos sistemas sociais de hierarquização desses sujeitos e saberes, para investigação dos sentidos do mundo e seus processos de construção, distribuição, reprodução e transformação. (Jordão, no prelo) 
Associando as duas citações de Jordão à formação de professores, vejo que a pedagogia crítica estabelece uma relação assimétrica entre 0 professor e o pesquisador no contexto de pesquisa, cabendo ao segundo fazer as intervenções consideradas necessárias para poder descortinar os aspectos que o professor ainda não consegue enxergar. No letramento crítico, amplia-se a liberdade de discussão, dando início a um processo de agência do professor. Apesar das idiossincrasias dessas duas abordagens, tenho percebido nos trabalhos de formação continuada de natureza colaborativa dos quais participo, principalmente na fase inicial, que existe um sentimento de ansiedade ou um desejo, por parte do professor colaborador, de que o pesquisador apresente respostas para os 'problemas' do seu contexto local, conforme exemplifico nas duas narrativas abaixo:

P1: A minha dificuldade maior [...] como [...] eu tinha vindo de curso de inglês, na época, eu acho que [...] oito ou nove anos [...] e foi logo no primeiro encontro do [...] pesquisador, ele começou a falar de cidadania e pra mim, eu assim [...] falava: “Não, mas eu tenho que ensinar o conteúdo". Então, assim não foi fácil pra mim também, mas eu vi que da maneira que eu estava trabalhando [...] não tava legal, não tinha resultado (excerto extraído de palestra $\left.{ }^{15}\right)$.

P2: Quando surgiu a oportunidade de eu participar do projeto do professor pesquisador, eu falei: "Nossa!", eu já assim... queria uma inovação, algo diferente, porque eu percebi que em minhas aulas [...] eu não tinha resultado com meus alunos. [...] passei dois meses trabalhando o conteúdo, mas na hora em que o aluno tem que colocar num contexto ou numa fala ou

\footnotetext{
${ }^{15}$ As duas narrativas foram coletadas a partir de uma palestra proferida pelas duas professoras participantes da pesquisa colaborativa onde relataram o início de um trabalho entre universidade e escola pública.
} 
reconhecer um texto, ele não consegue associar com o que eu trabalhei. (palestra)

A partir do primeiro excerto, percebo que havia um sentimento de angústia da professora $2^{16}$ em relação à aprendizagem do aluno. Como havia certa relação de confiança em função de seu vínculo de formação inicial com o meu trabalho de professor formador, interpreto que a professora via em mim, pesquisador, uma pessoa externa que pudesse trazer algo que resolvesse o problema local.

Além disso, a experiência com essa pesquisa me faz refletir sobre os propósitos que lançamos no início de um trabalho colaborativo. O pesquisador, com suas amarras resultantes de suas perspectivas teóricas, também projeta muitas expectativas dentre elas a de que pode trazer contribuições por meio de uma ação intervencionista local. Sobre as amarras, Britzman (1997) afirma que somos formados por alegorias que nos amarram e nos impedem de ver outras possibilidades. Tal consideração se reflete na narrativa da professora 1. Ela relata sua experiência de professora de curso livre de línguas, que presumidamente utilizava algum tipo de metodologia que se voltava para o aspecto cognitivo com ênfase nos conteúdos gramaticais no ensino da língua inglesa. Apesar de a proposta de intervenção ter causado estranhamento, ela resolveu dar crédito ao meu trabalho como pesquisador, uma vez que, da mesma forma que a professora 1, não avaliava o resultado de sua atuação de forma positiva.

\footnotetext{
${ }^{16}$ A professora 2 foi minha aluna nos cursos de graduação em Letras e de especialização em língua inglesa, nos quais foi minha orientanda de trabalho de conclusão de curso. Esse fato talvez tenha contribuído para que se voluntariasse ao trabalho colaborativo entre universidade e escola pública.
} 
É oportuno ressaltar ainda, o fato de que, na medida em que as professoras expunham suas preocupações, reflito que, imbuído de um sentimento emancipatório naquela fase da pesquisa, busquei apresentar alternativas metodológicas para que as professoras as reinterpretassem para 0 seu contexto local. Embora houvesse o propósito de reinterpretação e não o de mera aplicação de propostas, essa postura revela uma lógica da emancipação fundamentada na desigualdade e suspeita, conforme discuto mais adiante com base em Rancière (2010).

Retomando as premissas sobre emancipação do início desta seção: se emancipar estaria relacionado a fazer com que as pessoas pensem por si mesmas, que tomem suas próprias decisões e que cheguem às suas próprias conclusões, parece-me incoerente que um externo tenha que desempenhar o papel de desvelar uma verdade ou de apontar os caminhos a serem seguidos para um contexto que não Ihe é familiar. Assim, há uma discrepância na premissa principal da emancipação. Essa lógica, segundo Rancière (2010), introduz uma noção de dependência na realização da emancipação, isso porque os emancipados permanecem dependentes da verdade e do conhecimento a eles revelados pelo emancipador.

Conforme a visão marxista que fundamenta a pedagogia crítica, a emancipação é feita por aquele que não está contaminado pelos trabalhos do poder e, no contexto das duas narrativas apresentadas, por aquele que não está contaminado com os problemas da sala de aula. Rancière (2010) exemplifica essa situação no âmbito educacional colocando em oposição os dois participantes principais: os professores sabem e os alunos ainda não sabem, sendo assim, o papel do professor é de explicar o mundo aos alunos e 
o papel dos alunos, por sua vez, é de se tornarem conhecedores como o professor. Essa lógica também pode ser transposta para a relação pesquisador-professor, na qual o pesquisador sabe o que é melhor para o professor, retomando o título deste capítulo, ou ainda para as políticas públicas curriculares ${ }^{17}$ que nem sempre consideram o conhecimento local.

Três principais contradições na lógica da emancipação são apresentadas por Rancière (2010). A primeira delas está relacionada à dependência. O emancipado é dependente da intervenção do emancipador, baseado no conhecimento que é fundamentalmente inacessível ao emancipado. A segunda refere-se à relação de desigualdade. O emancipador é quem sabe mais e pode, então, desempenhar a ação de desmistificação. 0 emancipador ocupa uma posição superior. Para que a superioridade possa existir, o emancipador precisa da inferioridade do emancipado. A última está ligada à desconfiança e à suspeita. É concebida no fato de que não devemos acreditar no que vemos ou sentimos e que precisamos de uma outra pessoa para nos dizer o que estamos presenciando e dizer quais são as alternativas.

O que essas três considerações possuem em comum? Elas partem da premissa de que crítica é algo inacessível ao emancipado. Assim, o aspecto crítico relaciona-se a um nível hierárquico superior de percepção crítica, sendo esta apenas realizada por alguns especialistas, tais como o crítico literário, o

\footnotetext{
${ }^{17}$ Um exemplo disso pode ser identificado nas visões antagônicas propostas para o contextos de âmbito nacional e estadual. As OCEM sugerem que os professores reinterpretem as orientações para os contextos locais. As Diretrizes Curriculares para o Ensino de Língua Inglesa do Estado de Mato Grosso do Sul, por sua vez, prescrevem listas de conteúdos, seguidos de ações que criam mecanismos de controle como planejamentos e plataformas online para tentar homogeneizar as práticas dos professores de Língua Inglesa, sem considerar os conhecimentos e práticas locais. (MACIEL, 2011; 2012).
} 
crítico de cinema, entre outros, conforme aponta Monte Mór (2012). Para a autora, a crítica também pode acontecer quando há uma quebra do círculo hermenêutico interpretativo ou uma ruptura no ${ }^{18}$ habitus hermenêutico com base em Ricoeur (1978). Em outras palavras, quando o professor ou o aluno, após um momento de interação no qual vários posicionamentos são colocados, diz: 'sabe que eu não pensava assim?'. Nesse momento, o elemento crítico estaria mais voltado para o aspecto de percepção crítica que pode ser feita por qualquer pessoa independentemente de sua escolaridade. Essa quebra também acontece na percepção do pesquisador ao propor uma atividade para o professor e este redefine a sugestão dizendo: mas e se fosse dessa outra maneira que poderia atender mais o meu contexto local? Nesse momento, há também uma quebra de círculo interpretativo do pesquisador, que inicialmente não havia considerado tal possibilidade.

Neste sentido, o letramento crítico das políticas linguísticas e processo colaborativo de formação continuada de professores parte

\footnotetext{
${ }^{18}$ Entendemos que habitus hermenêutico corresponde a uma prática de interpretação que assume a linguagem como sendo transparente e capaz de captar totalmente a realidade. Realidade esta concebida de forma objetiva, totalizante e mensurável. Uma das consequências dessa prática de leitura e interpretação e que parece predominar em muitos contextos de ensino de língua inglesa, dentre outros, é tomar a intenção do autor de determinado texto ou evento como verdade única, excluindo assim, a possibilidade dos aprendizes construírem outras verdades relacionadas a partir do contexto específico do qual atribuem e constantemente reatribuem significados. Esse habitus hermenêutico não permite que o leitor questione a intenção do autor e/ou a ideia central ou aquilo que está por trás das aparências do texto ou do evento [...] a ideia de ruptura significa elaborar interpretações diferentes daquelas já consagradas, historicamente, por certos grupos sociais de prestígio [...] um exemplo de ruptura nesse habitus crítico é justamente o reconhecimento de que a natureza da linguagem é maleável, paradoxial e, portanto, passível de constantes transformações e reinterpretações, conforme aponta Bakhtin (1999). (MACIEL e TAKAKI, 2011, p. 34)
} 
principalmente da premissa de que todos possuem abstração crítica, conforme defendido por Monte Mór $(2011,2012)$. Para o contexto dessa pesquisa, tanto este pesquisador, quanto as professoras colaboradoras desempenham papéis importantes no processo de percepção e ampliação crítica.

Esse fato ocorreu em vários momentos do meu trabalho com as professoras ao reiterpretarmos dois documentos oficiais (estadual e federal) para redefinição para o contexto local, segundo os preceitos da teoria dos letramentos. Tanto eu, pesquisador, quanto as professoras, nos deparávamos com quebras no processo interpretativo, ou seja, o aspecto crítico estava presente em vários momentos, dando início a um processo de agência e autoempoderamento das professoras. Essa quebra também ocorria nos momentos de interação entre as professoras com seus alunos, ou até mesmo entre os próprios alunos, na percepção de leitura de mundo ao implementar os projetos que havíamos planejado para abordar o aspecto do letramento crítico.

Um exemplo da aplicação da proposta pode ser ilustrado quando a professora abordou o letramento visual para problematizar o papel da mulher a partir de uma propaganda de carros importados, conforme a figura a seguir. 


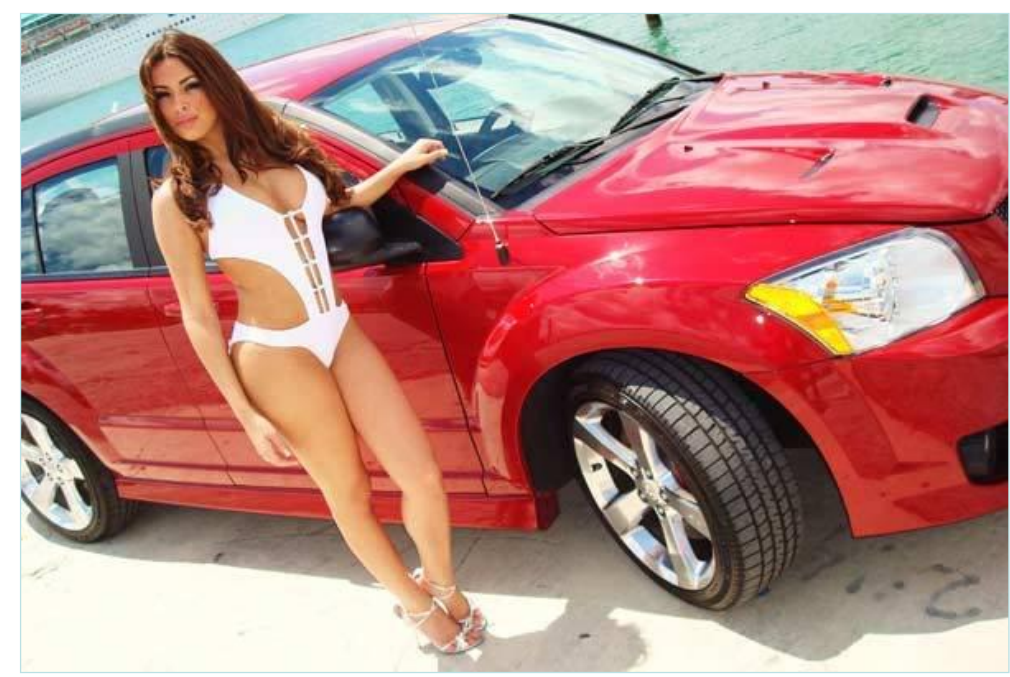

Why do they always have beautiful women next to cars?

Figura1: Slide ${ }^{19}$ apresentado pela professora 1 em MSPower Point@ para abordar o letramento visual.

$\mathrm{Na}$ ocasião, a professora presumia que no final da discussão, os alunos iriam perceber o papel ilustrativo atribuido ao gênero feminino, estabelecendo-se uma figura de consumo, para atrair a atenção do público masculino, reduzindo-se a figura feminina a um objeto de prazer e consumo, igualmente ao produto que estava sendo anunciado, e colocando-a em um patamar inferior em relação ao gênero masculino. Quando a professora questinou por que a imagem de uma mulher bonita foi utilizada na propaganda

${ }^{19}$ Além desse slide, vários outros foram utilizados pelas professoras. A imagem da mulher nesse slide foi para contemplar 0 aspecto de descrições físicas presentes nas Diretrizes Curriculares do Estado de Mato Grosso do Sul. Esse aspecto foi trabalhado, mas não como uma mera descrição de traços físicos. As professoras destacaram temas como o cuidado excessivo do corpo, o uso de anabolizantes já que vários dos alunos frequentam academias, o padrão de beleza valorizado pela mídia e o uso de imagens de mulheres em propagandas que não se referem exclusivamente a produtos voltados para elas. $\mathrm{Na}$ negociação com as professoras, foram contemplados os dois documentos oficiais: o tópico: descrição física (diretriz curricular local), mas com as visões filosóficas de linguagem e educação presentes nas Orientações Curriculares para o Ensino Médio (OCEM-LE). 
de automóvel, um dos alunos então respondeu: "Ah, professora! São dois sonhos de consumo do homem: ter um carro novo e uma mulher bonita". Nesse momento, houve uma quebra do círculo interpretativo da professora, que não esperava esse tipo de resposta.

Além disso, abriu-se espaço para que a professora e os alunos discutissem e identificassem os artefatos que produziram os efeito de sentido por meio da utilização de recursos multimodais, tais como a escolha de cores, imagens, disposição dos objetos e intertextos. A partir de então, perceberam como interpretações foram múltiplas, com suas verdades situadas dentro de cada contexto socio-histórico dos intérpretes. A discussão não se limitou à questão levantada pelo aluno, outras constatações foram feitas, inclusive ao aspecto de gênero que a professora inicialmente esperava abordar.

Outro exemplo ilustra as diferentes perspectivas, agora com as visões do pesquisador colaborador e das professoras, conforme os excertos ${ }^{20}$ abaixo. Nessa situação, negociávamos a escolha de um texto para se lidar com o tema "violência". A escolha do tema partiu do pesquisador, para oportunizar os aspecto do letramento crítico, por meio da ampliação da visão de mundo do aluno (Monte Mór, 2010).

\footnotetext{
${ }^{20}$ Parte das frases foram suprimidas, bem como algumas sequências. Meu objetivo em ilustrar a negociação durante o processo coloborativo é mostrar como as professoras possuem mais percepções críticas sobre o contexto local. Durante a pesquisa, foram utilizados vários instrumentos de coleta de dados, para registrar o trabalho colaborativo com as professoras, tais como entrevistas, gravação das reuniões em áudio e em video, elaboração de aulas. Embora o enfoque da pesquisa fosse as professoras, durante a fase de implementação, verificamos a necessidade de também ouvir os alunos, uma vez que as professoras sentiam se desconfortáveis no descolamento de determinadas práticas. Decidimos, então, distribuir cinco diários para cinco salas participantes. Além disso, os mesmos alunos e outros escolhidos de forma aleatória foram entrevistados durante e ao término do ano letivo.
} 
P2: Eu já baixei o texto [conversa via skype - texto enviado pelo pesquisador]

$P:$ [...] será que dá para trabalharmos essa questão da violência [...] como vocês gostariam de abordá-lo na escola?

P2: Por que esse texto é lá do Rio?

P: Esse texto é sobre o Rio [manchete: corrupção de policiais] P2: [...] um problema que a gente tem aqui na escola J.M.H.R. [...] é que as alunas estão brigando, ontem mesmo chamaram a patrulha porque ela [diretora] viu uma briga de menina, agora eu não sei que link a gente pode fazer desse texto com essa questão do caso da violência aqui.

$P$ : mas não precisa ser desse texto [...] vamos discutir como podemos trabalhar a questão da violência, trabalhando com aspectos de multimodalidade e do letramento crítico [...]

P2: Então, porque aí a gente pode mostrar o trailer que você falou do filme tropa de elite e entrar nesse texto, e daí desse texto a gente pode fazer um link lá e chamar mais atenção para a violência na escola

$P$ : É [...] pode começar com violência em vários contextos, talvez [...]

P2: Então, a gente pode puxar o link e trazer para cá [...] onde nós estamos [...] não temos favelas, mas nas escolas de Campo Grande têm ocorrido esse tipo de violência

P1: Quando você planeja uma coisa, quando você vai lá, na hora nunca sai como você planejou

$P$ : não tem receita né, depende do contexto

P1: Eu penso assim [...] dá pra levantar com eles algumas situações de violência e entrar com algum texto e ver qual será o caso mais recorrente e trabalhar e depois [...] a gente pode trabalhar esse também do Rio [...]

P2: E as coisas vão surgindo, eu falo uma coisa aí você fala outra coisa $[\ldots]$

Embora este pesquisador demonstrasse o conhecimento teórico sobre a proposta, as interações mostram que não houve uma relação 
hieráquica de crítica que colocasse o pesquisador em uma posição privilegiada em relação às professoras e com isso pudesse apresentar uma resposta pronta para o referido contexto. Interpreto a conversa acima como um exemplo em que a lógica de igualdade entre o pesquisador e as professoras foi mantida.

Apresento, a seguir, o relato dos alunos e suas percepções acerca da proposta das professoras.

A1: E a aula começou com duas perguntas: Qual era o conceito de violência? Que tipo de violência conhecemos? [...[ começamos a ver imagens [...] em pouco tempo, os alunos, sem perceber, já estavam dando opiniões e interagindo com a aula [...] com a participação dos colegas percebemos que [...] em filmes, desenhos, games, contém incentivos a violência [...] no final da aula todos saimos pensativos e nos perguntando [...] - Diário de campo.

A2: A turma tem aceitado muito bem as atividades, tem participado dando opiniões, fazendo perguntas, e ao mesmo tempo que discutimos um tema tão amplo e complexo nem observamos que estamos aprendendo inglês - Diário de campo.

A12: Assim [...] tipo pra pensar [...] pode colocar isso na nossa vida [...] entendeu? Que nem a violência no trânsito [...] Entrevista.

A3: Além da gente aprender, faz a gente refletir um pouco Entrevista.

A5: Fomos para a sala de video [...] tivemos uma aula muito interessante [...]acho que aulas destas deveriam ter acontecido em todas as séries do ensino fundamental e médio [...]faz os alunos refletirem [...] a violência é um tema muito polêmico [...]

- Diário de campo.

Esses excertos foram coletados dos alunos após algumas semanas de aplicação das atividades que foram elaboradas colaborativamente entre as 
professoras e este pesquisador, conforme alguns excertos mostrados anteriormente. Havia, por parte das professoras, algumas dúvidas sobre a aprendizagem dos alunos uma vez que não se adotava uma linearidade com sequencias gradativas mensuradas em atividades com respostas fechadas. Decidimos então distribuir cinco diários de campo em cada sala. Após dois meses de trabalho, os alunos que escreveram os diários foram entrevistados. O aspecto crítico foi uma das questões mais valorizadas pelos alunos que relatavam que suas percepções eram levadas em consideração, bem como percebiam que as verdades eram contingentes e situadas.

Para dar início ao processo de agência das professoras, a pesquisa não buscou uma abordagem com passos pré-definidos a serem seguidos para que as professoras chegassem a uma percepção crítica. Sobretudo, não se esperava que as professoras refletissem sobre aquilo que este pesquisador previamente havia cogitado, ou seja, você será crítico se você refletir sobre aquilo que eu gostaria que você refletisse. Caso contrário, a reflexão ocorreria apenas de forma unilateral e não haveria espaço para a auto-crítica do pesquisador. Diferentemente dessa visão, ao abordar sobre os objetivos emancipatórios na educação, bem como o seu aspecto crítico, Brydon (2012a, p. 20) afirma que "os professores não podem ser vistos apenas como implementadores de políticas produzidas em outros lugares". Mais especificamente, entendo que os professores não são meros aplicadores de teorias, nem são aqueles que possuem um nível de abstração crítica inferior ao do pesquisador.

Sob essa ótica, os professores são aqueles que informam a universidade sobre o que está acontecendo na sala de aula, não havendo, 
assim, uma separação entre a teoria que é produzida na universidade e a prática da sala de aula. Brydon (2012b) também defende a ideia de que o conhecimento é co-produzido e não é apenas produto da universidade, reconhecendo, assim, o valor de cada pessoa. Nesse mesmo raciocínio, Cummins e Davison (2007, p. 964) apontam que há uma linha de mão dupla entre teoria e prática: "prática gera teoria, que por sua vez, age como um catalizador para novas direções na prática, que então informa a teoria em um processo contínuo", ou seja, por meio de uma relação dialógica, a prática informa a teoria e a teoria informa a prática. Feitas tais considerações, discuto a seguir a noção de emancipação revisitada, como alternativa para a formação de professores e alunos.

\subsubsection{A lógica da emancipação revisitada}

Os trabalhos de Biesta e Rancière abriram espaço para que eu pudesse repensar o trabalho de formação de professores e que considerasse 0 aspecto local no qual a emancipação não está relacionada em um pensamento vertical ao se considerar o outro [as professoras]. Para tanto, dois argumentos importantes são apresentados por Biesta (2008). O primeiro é fundamentado na constatação da crítica de Rancière (2010), sobre a lógica da emancipação moderna, que visa a problematizar o papel emancipatório relacionado ao propósito de desmistificação. Nessa perspectiva, a 'velha' emancipação valoriza a forma vertical de pensamento que se preocupa em libertar as pessoas do trabalho do poder, cabendo ao emancipador descortinar as verdades como uma espécie de mestre 'explicador'. Biesta (2008) remete esse tipo de pensamento ao termo denominado por Gaston Bachelard como 'ciência do escondido'. Em outras palavras, nessa ótica, desacredita-se das 
experiências e das aparências, conforme as incoerências presentes na lógica da emancipação pela sua noção de desigualdade, dependência e suspeita, apresentadas por Rancière (2010).

O segundo argumento representa uma alternativa para responder aos problemas expostos pela crítica de Rancière. Para tanto, Biesta (2008) recorre ao conceito Faucautiano de 'eventalização'. O autor afirma que Foucault o ajudou a compreender os trabalhos do poder de uma forma diferente e mais profunda, uma vez que rejeita a ideia de que o conhecimento é usado para se combater o poder. Diferentemente da visão iluminista, Foucault considera que poder e conhecimento não são 'entidades' ontologicamente separadas e, portanto, a emancipação não consiste na 'vitória' do conhecimento sobre o poder. Não há um conhecimento puro, simples e não contaminado pelo poder.

Para Biesta (2010, p. 174), a 'eventalização' significa "complicar e pluralizar nossa compreensão sobre os eventos, seus elementos, suas relações e seus domínios de referência." Qual seria, então, a implicação disso para a educação? Não se trata de um aspecto crítico que tem como base um alto nível de abstração, não busca materializar as causas de determinados problemas, nem visa a libertar o outro das estruturas do poder, ou ainda, tornar as interpretações mais verdadeiras ou válidas. No entanto, a 'eventalização' pode, sim, validar as experiências de todos. Trata-se, portanto, de valorizar as verdades situadas ${ }^{21}$. A 'eventalização' funciona como uma lógica emancipatória contingente em um discurso de poder/conhecimento.

${ }^{21}$ Ver também Vattimo $(1985 ; 2004)$ - sobre o conceito de pensamento fraco. 
O processo de emancipação, por sua vez, estaria na ação crítica de explorar alternativas e não no propósito de se buscar uma verdade e uma autenticidade. Por essa ótica, os conceitos [verdade e autenticidade] são considerados questionáveis e, por conseguinte, entende a verdade como contingente, complexa, dinâmica e situada. Essa nova lógica poderia também estar relacionada ao aspecto de desconstrução que visa questionar o que temos como certo, para então se perceber o que se faz singular, contingente e produto de restrições arbitrárias. Valoriza-se, nesse caso, a pluralidade e a multiplicidade de explicações para os fatos, para os eventos, para as interrelações e para os domínios de diferença.

A ação crítica estaria relacionada em se perceber algo que representa apenas uma faceta das várias possibilidades. Portanto, não é o papel do emancipador [pesquisador] libertar o outro [professor], mas expô-lo a uma oportunidade igual, experimental para todos [inclusive para o próprio pesquisador], conforme atitudes ou procedimentos pedagógicos 'tradicionais' em que se preservam as relações hierárquicas de conhecimento, de experiência ou de liderança. Para Biesta, "a nova emancipação não é algo que é feito para pessoas, mas ao invés disso, é algo que é feito por pessoas $[\ldots]^{22}$ as pessoas não precisam esperar até que os emancipadores lhes digam o que podem mudar" (2008, p. 175). Em outras palavras, a emancipação não é resultante de uma relação de dependência e não funciona como a 'ciência do escondido'. Assim, ao invés de se buscar as verdades por trás das aparências, começa-se pelo que é visível. Muda-se, então, a topologia vertical para

\footnotetext{
${ }^{22}$ Grifo meu.
} 
horizontal na qual não se pressupõe uma posição de maestria (Rancière, 1995).

Pode, então, o leitor se questionar: mas isso quer dizer que não precisamos dos outros? Ryther (2008, p. 180) se remete a Rancière (1989) para dizer que "ainda precisamos dos outros para a emancipação, não para sermos desmistificados, mas para dar combustível às nossas paixões e desejos por outro mundo [...] enquanto nos emancipamos, não nos isolamos dos outros." A emancipação [revisitada, como propus no título deste trabalho] tem por objetivo, segundo Biesta (2010, p. 78), "empoderar os alunos [professores] a ter controle de suas próprias agendas educacionais." Ocupam, nesse sentido, as posições tanto de sujeito emancipador quanto de sujeito emancipado, em um processo contínuo de rupturas na relação com o outro, no qual suas experiências são reconfiguradas dando início, segundo Biesta (2010), a um processo de sujeitificação ${ }^{23}$. A partir desse estudo e da interpretação como pesquisador, entendo isso como um processo contínuo em situações educacionais como apresentadas aqui. Além disso, na emancipação horizontal não se objetiva descobrir uma verdade, confrontar o que é dito com o que é feito nos trabalhos colaborativos de formação de professores.

Essas afirmações podem ser relevantes, pois apresentam uma perspectiva para a formação de professores sem tomar como base um trabalho

\footnotetext{
${ }^{23}$ A sujeitificação "decompõe e recompõe os relacionamentos entre as maneiras de fazer, de ser e de dizer que definem a organização perceptível da comunidade" (Rancière 1995, p. 40, apud Biesta 2011, p.150). Portanto, trata-se de um processo contínuo e não é necessariamente produzido pela educação. Para aprofundar a leitura sobre sujeitificação, ver Biesta 2010, Good education in the age of measurement: ethics, politics and democracy.
} 
instrumental, neoliberal (GRAY; BLOCK, 2012; CLARK; MORGAN, 2012), de padronização de competências pré-definidas ou de reprodução em massa, conforme o modelo de formação de professores multiplicadores de perspectivas pré-estabelecidas. 


\section{CONSIDERAÇÕES FINAIS}

Diretora adjunta: Meu nome é $A$. G. C. sou diretora adjunta da E.E.J.M.H.R., situada em Campo Grande Mato Grosso do Sul num bairro de periferia [...] Desde de 2009, as professoras P1 e P2 têm desenvolvido um projeto, sob a supervisão de um professor pesquisador, sobre o letramento critico na disciplina de Inglês e de lá pra cá, muitas coisas mudaram dentro da escola. Podemos pensar que a questão primeira foi a valorização da disciplina devido à mudança de metodologia que as professoras tiveram nas suas aulas, aí houve essa valorização. Porque as professoras têm trabalhado com 0 letramento crítico do Inglês então não é somente a gramática, mas é a contextualizado, então elas tem trabalhado, por exemplo, temas como: violência, gravidez na adolescência, trânsito [...] As professoras tiveram, assim, uma iniciativa colaborativa com a escola e com elas mesmas, aquela vontade de aprender mais, de buscar, porque elas não receberam nada por isso, elas fizeram esses estudos no turno, elas trabalhavam normalmente, 40 horas e fora isso elas fizeram encontros finais de semana, a noite, enfim, os estudos foram todos além, elas não pararam de trabalhar pra fazer esses estudos. Com isso, a escola também em 2009 teve um aluno que foi premiado como jovem embaixador, foi selecionado aqui um dos alunos que foi para os Estados Unidos e ano passado em 2011 as duas alunas representantes de Mato Grosso do Sul de jovem embaixador foram aqui da escola, então a gente percebe como os alunos se interessam mais [...] elas utilizam muito os recursos midiáticos, então houve a iniciativa de montar 0 projeto e submetê-lo a uma emenda parlamentar, de um deputado aqui do estado e elas acabaram com esse projeto recebendo um data show, um notebook, para esse trabalho que ficou destinado para a língua estrangeira moderna - inglês [...] porque elas utilizam muito esse recurso [...] Gostaria também de enfatizar a importância das universidades estarem abrindo essa oportunidade para as escolas públicas, porque 
muitas vezes e fácil falar que a escola pública está derrubada, que os professores não se empenham, não é? Parece que a culpa cai muito sobre nós que estamos aqui, a direção, os professores, enfim, e nós concluímos com esse projeto que se houver iniciativa das universidades em saírem também dos muros das universidades e virem pra escola, com certeza vai encontrar um grupo muito grande de professores que querem melhorar a sua prática, sua metodologia. Eu vejo que é uma via de mão dupla, não é? Os dois segmentos ganharão: tanto as universidades, quanto a escola.

Inicio as considerações finais com o depoimento da diretora adjunta por ser uma pessoa que não estava diretamente envolvida como participante da pesquisa, mas que possui um olhar macro sobre a realidade da escola e do trabalho realizado neste estudo. Vejo neste depoimento um entre os vários discursos que fizeram com que eu ressignificasse a minha prática de professor formador e, com isso, comecei a olhar para a escola pública e seus integrantes de uma maneira diferente. Retomando parte do título desse trabalho quando me refiro a reconstruir conhecimentos e práticas locais, insiro o meu próprio conhecimento e prática no sentido de desenvolver uma postura acadêmica em relação ao outro. Destaco aqui o aspecto de saber ouvir o outro, da escuta atenta, ao mesmo tempo em que tento ler e compreender o outro, esta escuta também se remete à postura ética de ler a mim mesmo para entender 0 posicionamento do outro.

Essa minha visão está sendo reconstruída a partir do momento que começo a ver o trabalho de formação de professores que realmente considere o conhecimento local. Em geral, as pesquisas qualitativas de formação de professores, conduzidas na sala de aula, segundo Cummins e Davison (2007, 
p. 964), tipicamente enfocam "os comportamentos instrucionais, os modelos de interações entre professores e alunos, os processos de ensino-aprendizagem, os resultados associados com diferentes tipos de linguagem e atividades de letramento", ou seja, direcionam para os aspectos observáveis e, até mesmo mensuráveis por um pesquisador externo. Há, neste sentido, uma relação dialética entre sujeito e objeto, bem como a comprovação de hipóteses préestabelecidas pelo pesquisador. $\mathrm{O}$ trabalho proposto às professoras, nesta pesquisa, possui uma relação dialógica e isso tem contribuído para rever minha formação tradicional de formação de professores que estabelecia um distanciamento entre o pesquisador e o objeto sob investigação.

Com respeito à formação de professores, busquei leituras para a análise da formação das professores investigadas, levando em conta os dados obtidos. Apesar das várias orientações teóricas na formação de professores no Brasil, Paiva (2003) aponta aspectos limitadores com relação à formação préserviço que destina pouca carga-horária às disciplinas específicas de formação de professores, além da precariedade de recursos dos cursos de Letras. Cummins e Davison (2007), por sua vez, criticam a formação de professores uma vez que as pesquisas em educação e ensino de línguas têm enfatizado o uso de teorias. Os autores (op. cit., 963) apontam que pouco tem sido pesquisado sobre o papel da teoria "na mediação da relação entre a pesquisa e política e a prática." Segundo eles, é muito comum ouvir discursos de propostas apresentadas aos professores de serem 'apenas teorias'. Essa visão representa uma lacuna sobre o papel que a teoria tem sobre os fatos. Implica, ainda, que resultados de pesquisas não podem ser diretamente aplicados em 
vários contextos, mas que a teoria permite generalizações de previsões de resultados e seus efeitos de várias intervenções sobre diferentes condições.

Nesse sentido, Britzman (1991, p. 2) chama atenção para o fato de que teorizar "nos reorienta para o trabalho do professor e requer um entendimento não apenas simplesmente das estruturas escolares ou habilidades para se ensinar, mas da construção da identidade do professor." Assim, o desenvolvimento de autonomia e agência das professoras foram aspectos que emergiram nos dados desta pesquisa.

A teoria tem a função de não somente abordar questões que acontecem na sala de aula, em uma concepção mais restrita, mas também possui a função de investigar a interação da sala de aula. Essa interação é influenciada pelos discursos sociais que as cercam. Cummins e Davison (2007, p. 964) apontam que há uma linha de mão dupla sobre teoria e prática: "prática gera teoria, que por sua vez, age como um catalisador para novas direções na prática, que então informa a teoria, em um processo contínuo". Em outras palavras, por meio de uma relação dialógica, a prática informa a teoria e a teria informa a prática. Neste sentido, a leitura dos documentos oficiais (Referencial Curricular Estadual e as OCEM) e a relação com a prática contribuíram não somente para reavaliar as teorias, mas também para reorientar o trabalho local na escolha de temas, de propostas teóricas e da verificação sobre de verificar como essas questões são ressignificadas na prática.

Uma das características da pesquisa qualitativa, segundo Duff (2007) é sua possibilidade de explorar perspectivas e interpretações internas, ao invés de apenas confiar no que pode ser observado ou mensurado do lado de fora, como em paradigmas de pesquisas mais tradicionais. Professores 
como participantes internos em relações educacionais têm o potencial de "ver do lado de dentro" esses relacionamentos. Seus olhares de dentro não podem ser duplicados por aqueles que estão em uma posição externa, como é geralmente $\mathrm{o}$ caso dos pesquisadores externos. Por outro lado, durante 0 processo, podem surgir questões que não eram aparentes, mas potencialmente identificáveis por aqueles que estão distanciados. Nesse sentido, Duff (op. cit.) aponta que a pesquisa qualitativa tem o potencial de unir as micro e as macro análises, as perspectivas de dentro e de fora sobre as questões de determinados fenômenos que, de outra perspectiva, não seriam observáveis.

Seguindo essas teorias sobre pesquisa e análise, nos capítulos I e II, apresento conflito de objetivo em relação ao que deva ser ensinado nas aulas de língua inglesa. Observo esse conflito em um relato de uma professora que expressa a língua dever ser estudada segundo questões culturais, sendo estas ligadas aos países do círculo interno conforme o modelo de Kachru. Há ainda o posicionamento de uma participante da pesquisa que fala sobre o uso de estratégias e a comparação dessas com cursos de idiomas. Essa visões refletem que a expectativa de um currículo que apresente conteúdos estáveis. Sobre esse aspecto, Kress (2008, p. 255) afirma que nas práticas e pensamentos educacionais existe um senso comum de que "o currículo é constituído pelas características da sociedade que é essencial transmitir para as próximas gerações os conhecimentos ou as habilidades de valores já naturalizados." Em outras palavras, numa visão conservadora, o currículo incorpora os significados, os conhecimentos e os valores importantes para uma sociedade atual. Similarmente, Hoveid e Hoveid (2008) afirmam que na 
tradição ocidental do pensamento e do discurso educacional, o conhecimento prático (dinâmica de pensar, falar, agir, escrita pessoal) é frequentemente separado do conhecimento disciplinar. Dessa maneira, a função do currículo tem sido normatizar o que precisa ser ensinado, o que possibilita pouco espaço para reinterpretação local.

O aspecto fixo e o aspecto de controle também são característicos da filosofia humanista ocidental, conforme indicam Hoveid e Hoveid (op. cit.). Nela, toda pessoa tem uma essência única, fixa e coerente. Na visão pósestruturalista, por outro lado, o individuo é visto como diverso, contraditório, dinâmico, e que muda com o tempo histórico e espaço social. Esse aspecto dinâmico, mutante é utilizado para descrever o processo de mudanças conceituais do professor em relação ao seu papel formador na escola por meio de língua estrangeira. Os dados coletados das professoras durante os encontros previstos na pesquisa apontaram que os objetivos das professoras têm mudado da visão instrumental de ensino de língua no início do trabalho colaborativo e com o tempo elas passam a assumir um papel de formação.

Este argumento também é reconhecido por Gee (2001), ao afirmar que a identidade teórica surge em um contexto específico e que adquire múltiplas formas, quando em contato com diferentes contextos, tais como: identidade de natureza (relacionada a fatores pessoais), identidade institucional (derivada de uma posição reconhecida de autoridade), identidade discursiva (resultada do discurso dos outros), identidade de afinidade (determinada com a prática com grupos externos). Portanto, a ênfase está na natureza multifacetada de identidade e sua forma mutante em termos de ambientes externos. A agência, por sua vez, pode estar relacionada às maneiras com as 
quais os professores interagem com uma variedade de contextos educacionais, tais como o contexto escolar, a natureza da população de aprendizes, o impacto dos colegas, administração. Os dados desta pesquisa indicam que a agência não se refere apenas à autonomia na escolha dos temas e na alteração dos conteúdos propostos pelo documento oficial. Demonstra também o papel político das professoras em buscar agentes externos que possam colaborar com recursos financeiros para a aquisição de equipamentos para o uso de recursos midiáticos nas aulas de inglês, conforme relato da diretora adjunta.

A construção dos conceitos teóricos também pode se beneficiar da perspectiva pós-colonial que conforme (Bhabha, 2007) busca questionar os discursos de supremacia de conhecimento e cultura da modernidade, a visão etnocêntrica de pressupor conceitos de uniformidade, normalidade hegemônica e universalidade. Segundo o autor, essas visões são direcionadas à questão curricular, ao ensino de língua e cultura e à formação de professores.

A sociedade contemporânea possui características híbridas, metáfora usada na pós-modernidade que, de acordo com Latour (2009, p. 131), são "tão numerosas que ninguém mais entende como absorvê-las na antiga terra prometida da modernidade". Segundo o próprio autor, nem chegamos a alcançar a modernidade, mas o que a sociedade tanto valoriza são os saberes escolares herdados da visão iluminista moderna.

Neste sentido, Britzman (1997) aponta que é importante perceber que estamos ligados a uma forma de pensar que nos amarra a uma origem e que nos impede de ver outras maneiras, pois estamos presos às alegorias, uma vez que somos formados por visões de linguagens. No contexto desta 
pesquisa, as professoras relatam que começaram a ver outras possibilidades para o ensino a partir da leitura das OCEM e da negociação com o pesquisador. Essa experiência remete a Britzman que entende que talvez as professoras não conseguissem ver outras possibilidades devido às amarras de suas formações iniciais bem como o dia a dia da escola, ou seja, das amarras que tanto nos ajudam quanto nos impedem de ver. Ressalto aqui a ética de se ter consciência de que não é possível ver o outro tal como é, mesmo porque esse outro, numa visão pós-moderna é hibrido. Vários questionamentos emergem dessas reflexões durante a pesquisa.

Alguns desses questionamentos foram importantes para este pesquisador no processo colaborativo com as professoras: como eu me coloco nesse contexto como pesquisador? Como eu vejo as professoras? Como as professoras analisam os documentos impostos à escola? Como elas veem os alunos? Como os alunos relatam as mudanças ocorridas no processo?

Essas questões requerem uma ética que necessita colocar em prática o que Spivak (2005) chama de perder privilégios. Segundo a autora, essa ética disciplinaria o nosso privilégio de ter uma consciência crítica. $O$ privilégio é também um tipo de insularidade que corta o privilégio de se ter certo tipo de conhecimento do 'outro'. Assim, a visão crítica não estaria relacionada à visão de superação ou emancipação vertical.

Esse aspecto também é defendido por Britzman (1997) como uma necessidade de ética do pesquisador em relação ao seu ego, de como o pesquisador se auto-representa em suas discussões com o outro e quem é o outro nas pesquisas educacionais. A questão de representação, segundo Spivak (1993), pode correr o risco de cair no essencialismo, pois o pensamento 
pós-moderno se baseia na não estabilidade de significados, representações e experiências. Embora não abordada na tese, a "pedagogia fraca", com base em Vattimo $(1985,2004)$ emprega o conceito de contingência, segundo o qual as verdades precisam ser reconstruídas, reduzindo ao máximo a violência que começa de dentro de nós, enquanto formadores de professores que buscamos emancipar ou converter o outro segundo nossas convicções que nem sempre consideram o aspecto local. Levando em conta o conceito da contingência e sem a preocupação em buscar uma única verdade sobre a interpretação, esta pesquisa considera as proposições presentes nos relatos dos participantes como verdades contextualmente situadas e que podem sofrer alterações ao longo do processo.

Assim como iniciei as considerações finais com o depoimento da diretora adjunta, finalizo este trabalho como relato da Professora 1.

P1: Eu penso assim, Professor, um exemplo, eu tenho minha família, aí eu não gosto da minha família, mas vou levando. Eu tenho uma profissão, mas eu não gosto da minha profissão e vou levando. Muita gente é assim. Mas eu penso, que vida é essa de infelicidade? Eu tenho que acreditar no meu trabalho, eu tenho que acreditar que eu tenho uma função lá, porque se eu não acreditar que eu tenho um papel lá na escola, então eu posso me aposentar. É o trabalho, eu não vou lá só para ganhar meu salário e dar minhas aulinhas e acabou. Tem um monte de professor que pensa assim né. Eu tenho compromisso com a formação desses alunos. 


\section{REFERÊNCIAS BIBLIOGRÁFICAS}

ANGROSINO, M. Doing ethnographic and observational research. Oaks, CA: Sage, 2007.

APPLE, M. On the task of critical education scholar/activist. In: WINKLEWAGNER, R.; HUNTER, C.A.; ORTLOFF, D. H. Bridging the gap between theory and practice in educational research: methods at the margins. New York: Palgrave Macmillan, 2010.

APPADURAI, A. Grassroots globalization and the research imagination. Public Culture 12(1): 1-19. Minneapolis, MN: University of Minnesota Press, 2000.

BARTON, D.; HAMILTON, M. Local Literacies: a study of reading and writing in one community. London: Routledge, 1998.

BHABHA, H. K. The location of cuture. $5^{\text {th }}$ edition. New York: Routledge, 2007.

BHATT, R. M. World Englishes, globalization and the politics of conformity. In: SAXENA, M. E OMONIYI, T. Contending with globalization in world Englishes. Toronto: Multilingual Matters, 2010.

BIESTA, Gert J. J. Good education in the age of measurement: ethics, politics and democracy. London: Paradigm Publishers, 2010.

. Towards a new 'logic' of emancipation: Foucault and Rancière. In R. Glass et al. (eds), Philosophy of Education. UrbanaChampaign, IL: Philosophy of Education Society, pp. 169-177, 2008. 
;WINTER, Phillip. Coming into the world, uniqueness, and the beautiful risk of education: an interview with Gert Biesta by Philip Winter. Studies on Philosophy of Education. 30:537-542, 2011.

BLOMMAERT, J. The sociolinguistics of globalization - Cambridge approaches to language contact. Cambridge, C.U.P, 2010.

(Ed.). Language ideological debates. Mount de Gruyter:

Belin, 1999.

BOURDIEU. P. Contrafogos 2: por um movimento social europeu. Tradução: Andre Telles. Rio de Janeiro: Editora Zahar, 2001.

BRASIL. Orientações Curriculares para o Ensino Médio: Língua Estrangeira. Brasilia: MEC, 2006.

BRITZMAN, D. Practice makes practice: a critical study of learning to teach. Albany: State University of New York Press, 1991.

BRITZMAN, D. The tangles of implication. International Journal of Qualitative Studies in Education, vol. 10, no. 1, p. 31-37, 1997.

BRYDON, D.; COLEMAN, D. W. Renegotiating Community: Interdisciplinary Perspectives, Global Contexts. University of British Columbia Press, 2008.

BRYDON, D. Teaching English as an emancipatory literacy in local and global contexts. In: Fórum mundial da educação profissional e tecnológica. Florianópolis-SC,30/05/ 2012a.

- Reunião de grupo de pesquisa. In: I Brazil-Canada knowledge Exchange: developing transnational literacies. Aracaju-SE, 23/05/2012b. 
CANAGARAJAH, S. Reconstructing Local Knowledge. Journal of Language, Identity \& Education, 1:4,243 - 259., 2002.

. Reconstructing local knowledge, reconfiguring languages studies. In: CANAGARAJAH, SURESH. (ed.) Reclaiming the local in language policy and practice. Mahwah, NJ: Erlbaum, 2005.

After disinvention: possibilities for communication, community and competence. In: MOKONI, S. AND PENNYCOOK, A. (eds.) Disinventing and reconstituting languages. Toronto: Multilingual Matters LTD, 2006.

Ethnographic methods in language policy. In: RICENTO, T. An introduction to language policy: theory and method. $4^{\text {th }}$ edition. New York: Blackwell, 2009.

CILLIERS, P. Complexity, deconstruction and relativism. Theory, culture and society. Sage, 2003.

CLARKE, M; MORGAN, B. Education and social justice in neoliberal times: historical and pedagogical perspectives from two postcolonial contexts. In: M. HAWKINS (Eds.). Language teacher education: a social justice approach. Clevedon, UK: Multilingual Matters, 2012.

COPE, B.,KALANTZIS, M. Multiliteracies: literacy learning and the design of social futures. London: Routledge, 2000.

CUMMINS, J; DAVISON, C. Introduction: The global scope and politics of ELT: critiquing current policies and programs. In: CUMMINS, Jim; DAVISON, Chris. (Eds.). International handbook of English language teaching. Norwell: Springer, 2007.

DEWEY, M.; JENKINS, J. English as língua franca in the global context: interconnecedness variation and change. In: SAXENA, M. E OMONIYI, T. 
Contending with globalization in world Englishes. Toronto: Multilingual Matters, 2010.

DUFF, P. (2007). Qualitative approaches to second language classroom research. In: J. CUMMINS; C.; DAVISON (Eds.), Handbook of English language teaching, Part 2 (pp. 973-986) Philadelphia: Kluwer.

EDWARDS, R.; USHER, R. Globalisation and pedagogy: space, place and identity. 2 ed. New York: Routledge, 2008.

ESTADO DE MATO GROSSO DO SUL. Referencial Curricular para o Ensino Médio: Língua Inglesa. Campo Grande-MS: SED, 2008.

FABRÍCIO, B.F.; SANTOS, D. The (re)framing process as a collaborative locus of change. In: COOK,G.; NORTH,S. Eds. Applied Linguistics: a reader. London: Routledge, 2010.

FOUCAULT, M. A ordem do discurso. Tradução: Laura Fraga de Almeida Sampaio. Edições Loyola: Sao Paulo, 19 edição, 2009.

FREIRE, P. Pedagogia da autonomia: saberes necessários para à prática educativa. São Paulo: Paz e Terra, [1996], 15ª edição, 2002.

FREIRE, P. Pedagogia da tolerância. São Paulo: Editora Unesp, 2005.

GEE, J. Social linguistics and literacies: ideology in discourses. New York: Routledge, 1990.

GEE, J. Literacies, schools and kinds of people: educating people in the new capitalism. In: KALANTZIS, M.; COPE, B. (Eds.) Transformations in Language and learning: perspectives on multiliteracies. Common Ground, 2001. 
GEE, J. What video games have to teach us about learning and literacy. New York: Palgrave Macmillan, 2003.

GEE, J. Situated language and learning: a critique of traditional schooling. London: Routledge, 2004.

GEE, J. Language and learning in the digital age. New York: Routledge, 2011.

GEORVIEVA, M. ELF: from 'you sound like Dickens' to international English. In: SAXENA, M. E OMONIYI, T. Contending with globalization in world Englishes. Toronto: Multilingual Matters, 2010.

GIMENEZ, T.N. Reflexão crítica e a formação de professores de inglês. Contexturas, v. 13, p. 55-66, 2008.

GIMENEZ, T. N.; CRISTÓVÃO, V. L. L. (Orgs.) Teaching English in Context: contextualizando o ensino de Inglês. Londrina: UEL, 2006.

GIMENEZ, T.N. Diretrizes Curriculares e a sala de aula de língua estrangeira: diálogos (im)possíveis?. In: CORREA, Djane Antonucci; SALEH, Pascoalina Bailon de Oliveira. (Org.). Estudos da Linguagem e currículo: diálogos (im)possíveis. Ponta Grossa: Editora UEPG, 2009.

GRADDOL, D. English Next. Why global English May Mean the End of 'English as a Foreign Language'. Plymouth: The British Council, 2006.

GRAY, J.; BLOCK, D. The marketisation of language teacher education and neoliberalism: characteristics, consequences and future prospects. In: BLOCK, David; GRAY, John; HOLBOROW, Marnie (Eds.). Neoliberalism and applied linguistics. New York: Routledge, 2012. 
HARDT, M.; NEGRI, A. Empire. Cambridge, MA: Harvard University Press, 2000.

HEIGHAM, J.; SAKIU, K. Qualitative research in applied linguistics. New York: Macmillan Palgrave, 2010

HORNBERGER, N. (Eds.) Indigenous literacies in the Americas: language planning from the bottom up. Berlin: Mounton, 1996.

HOVEID, H.; HOVEID, M.H. Teachers' identity, self and the process of learning. Studies on Philosophy and Education. 27: 125-136, 2008.

HIGGINS, C.; NORTON, B. (Eds). Language and HIV/AIDS. Bristol, UK: Multilingual Matters, 2010.

IVES, P. Global English: linguistic imperialism or practical lingua franca? Studies in language and capitalism. 1: 121-141, 2006.

JENKINS, J. English as a lingua franca: interpretations and attitudes. World Englishes, Vol. 28, No. 2, pp. 200-207, 2009.

JÖNSSON, J.H. Beyond empowerment: changing local communities. International Social Work. 53 (3) 393-406, 2010.

JORDÃO. C.M. English as a foreign language, globalization and conceptual questioning. Globalization, Societies and Education, 7, 1: 95-107, 2009.

Abordagem comunicativa, pedagogia crítica e letramento crítico - farinhas do mesmo saco? In: ROCHA, Cláudia Hilsdorf; MACIEL, Ruberval Franco (Orgs.). Ensino de língua estrangeira, formação cidadã e tecnologia (no prelo). 
$\mathrm{KACHRU}, \mathrm{B}$. B. The alchemy of English: the spread, functions, and models of non-native Englishes. Urbana: University of Illinois Press, 1985.

KALANTZIS, M; COPE, B. Transformations in Language and Learning: Perspectives on Multiliteracies. Australia: Common Ground, 2001.

KALANTZIS, M; COPE, B. Learning by design. Melbourne: Common Ground, 2005.

KIRBY, A. Digimodernism: how new technologies dismantle the postmodern and reconfire our culture. New York: Continuum, 2009.

KUMARAVADIVELU, B. Understanding language teaching: from method to postmethod. Mahwah, NJ: Erlbaum, 2006.

KUMARAVADIVELU, B. A linguística aplicada na era da globalização. In: MOITA LOPES, L. P. (Org). Por uma Linguística Aplicada Indisciplinar. São Paulo: Parábola, 2006.

KIRKWOOD-TUCKER, T.F. (Ed.) Visions in global education: the globalization of curriculum and pedagogy in teacher education and schools: perspectives from Canada, Russia, and the United States. New York: Peter Lang., 2009.

$\mathrm{KRAMSCH}$, C. Foreign languages between knowledge and power. Applied Linguistics. 26:4, 545-567, 2005.

KRESS, G. Meaning and Learning in a World of Instability and Multiplicity. Studies on Philosophy and Education. Springer Science Business Media B.V., 2008.

KRESS, G. Literacy in the new media age. London: Routledge, 2004. 
KUNTZ , A. M. Representing representation. International Journal of Qualitative Studies. Vol. 23, N.4, July-August, 423-433, 2010.

KUROSAWA, F. Global justice as ethico-political labour and the enactment of criticial cosmopolitanism. Rethinking Marxism. 21, 1: 83-100, 2009.

LANKSHEAR, C.,KNOBEL, M. New Literacies: Changing Knowledge and Classroom Research. Buckingham: Open University Press, 2003.

LANKSHEAR, C.; KNOBEL, M. New literacies: everyday practices and classroom learning. $2^{\text {nd }}$ edition. New York: Open University Press. 2007.

LATOUR, B. Jamais fomos modernos. 2 edição. Tradução: Carlos Irineu da Costa. São Paulo: Editora 34, 2009.

LEE, E.; NORTON, B. The English language, multilingualism, and the politics of location. The International Journal of Bilingual Education and Bilingualism, 12(3), 277-290, 2009.

LINGARD, B. Global/national pressures on education systems: the Andrew Bell Public lectures. Discourse. Studies in the Cultural Politics of Education. Vo. 30, N. 3 September 235-238, 2009.

LUKE, A.; FREEBODY, P. (1997) Shaping the social practices of reading. In: MUSPRATT, S.; LUKE, A.; FREEBODY, P. (Eds.) Constructing critical literacies. St. Leonards, Australia: Allen \& Unwin, 1997.

MACIEL, R. F. Reported Implementation and Reaction of a New National Innovation in the private Sector in Brazil. The University of Reading. Reading. UK. Master Dissertation. Unpublished, 2001. 
MACIEL. R.F. Globalization, public schools and curricular proposals: challenges for teacher education in Brazil. Contexturas: ensino critico de língua inglesa. Vol. 16. São Paulo: APLIESP.

MACIEL. R.F. From innovation to language policy: towards a locus of research in Applied Linguistics. In: MACIEL, Ruberval Franco; ARAUJO, Vanessa Assis (Orgs.). Formação de professores de línguas: ampliando perspectivas. Jundiaí: Paco Editorial, 2011.

MACIEL. R.F.; TAKAKI, Nara Hiroko. Memes online: implicações para a construção do conhecimento sob a ótica dos novos letramentos. Contexturas: ensino crítico de língua inglesa. São Paulo, APLIESP, n. 18, p. 29-50, 2011.

MACIEL. R.F. Language policy and planning (round table). In: II Brazil-Canada knowledge Exchange: developing transnational literacies. Glendon CollegeToronto-CA,16/10/2012.

MAKONI, S.; PENNYCOOK, A. Disinventing and reconstituting languages. In: MAKONI, S.; PENNYCOOK, A. (eds), Disinventing and reconstituting languages. Multilingual Matters, Clevedon, 2007.

MATTOS, A. M. A.; VALÉRIO, K. M. Letramento crítico e ensino comunicativo: lacunas e interseções. Revista Brasileira de Linguística Aplicada, v. 10, n. 1, p. $135-158,2010$.

MATTOS, A.M.A. 0 ensino de inglês como língua estrangeira na escola pública: novos letramentos, globalização e cidadania. Tese de doutorado. Programa de Pós-graduação em Estudos Linguísticos e Literários de Inglês. Universidade de São Paulo, 2011.

MAY, S. Addressing the politics of language. In: MAY, S.; HORNBERGER, N.H. (Eds.). Encyclopedia of language and education, $2^{\text {nd }}$ edition, volume 1 : Language policy and political issues in education. New York: Springer, 2008. 
MaCARTY, T. Introducing ethnography and language policy. In: MaCARTY, T. (Ed.) Ethnography and language policy. New York: Routledge, 2011.

MCKLNNEY, C.; NORTON, B. Identity in language and literacy education. In: SPOLSKY, B.; HULT, M. F. (Eds.). The handbook of educational linguistics. Blackwell: Sussex, 2010.

MENEZES DE SOUZA, L. M.T. Para uma redefinição de letramento crítico: conflito e produção de significação. In: MACIEL, R. F.; ARAUJO, V. A. (Org.) Formação de professores de línguas: expandindo perspectivas. São Paulo: Paco Editorial, 2011.

MENEZES DE SOUZA, L. M.T. Language policy and planning (round table). In: II Brazil-Canada knowledge exchange: developing transnational literacies. Toronto-Canadá, 2012.

MENEZES DE SOUZA, L. M.T. Entering a culture quietly: writing and cultural survival in indigenous education in Brazil. In: MAKONI, S.; PENNYCOOK, A. (Eds.). Disinventing and reconstituting languages. Clevedon: Multilingual Matters, 2007.

MENKEN, K.; GARCIA, O. Introduction. In: MENKEN, K.; GARCIA, O. Negotiating language policy in schools: educators as policymakers. New York: Rotledge, 2010.

MORGAN, B.; RAMANATHAN, V. Critical literacies and language education: global and local perspectives. Annual Review of Applied Linguistics, Cambridge University Press, 2005, p. 151-169.

MORGAN, B. Learning how to read from students! In: MACIEL, R. F.; ARAUJO, V. A. (Org.) Formação de professores de línguas: expandindo perspectivas. São Paulo: Paco Editorial, 2011. 
MORIN, E. A cabeça bem-feita: repensar a reforma. repensar o pensamento. Rio de Janeiro: Bertrand Brasil, 2000.

MORIN, E. Ciência com consciência. Tradução: Maria de Alexandre e Maria Alice Sampaio Dória - Ed. Revista e modificada pelo autor $8^{\mathrm{a}}$ Ed., Rio de Janeiro: Bertrand Brasil, 2008.

MONTE MÓR, W. Línguas Estrangeiras. Projeto Político-pedagógico e Metodologias. IN: Salto para o futuro. Orientações curriculares para o ensino médio. SEED/MEC, 2007.

MONTE MÓR, W. Foreign languages teaching, education and the new literacies studies: expanding views. In: GONÇALVES, G.R. et. al (Orgs) New Challenges in Language and Literature. Belo Horizonte: FALE/UFMG, 2009.

MONTE MÓR, W. Critical literacies in the Brazilian university and in the elementary/secondary schools: the dialectics between the global and the local. In: MACIEL, R. F.; ARAUJO, V. A. (Eds.) Formação de professores de Línguas: expandindo perspectivas. São Paulo: Paco Editorial, 2011.

MONTE MÓR, W. Language policy and planning (Mesa redonda). In: II BrazilCanada knowledge exchange: developing transnational literacies. TorontoCanadá, 2012.

MONTE MÓR, W. Letramentos críticos e formação de professores: abordagens brasileiras (mesa redonda). In: Seminário letramentos transnacionais Brasil-Canadá. Universidade Federal de Sergipe, Aracaju, 24/05/2012.

MONTE MÓR, W. Caderno de Orientações Didáticas para EJA - Inglês. São Paulo: Secretaria Municipal de educação, 2010. Disponível em: <http://portalsme.prefeitura.sp.gov.br/Projetos/BibliPed/Documentos/publicacoe s/orienta_ing_portal.pdf $>$. Acesso em: 20/06/2012. 
NORTON, B. Identity, literacy and English language teaching. IATEFL. Cardiff, 2009. Disponível em: <http://lerc.educ.ubc.ca/fac/norton> acesso em: 01/07/2010.

NORTON, B. Language and identity. In. N. Hornberger and S. McKay (Eds). Sociolinguistics and language education. Clevedon, UK: Multilingual Matters, 2011.

NORTON, B. Identity and language learning: Gender, ethnicity and educational change. London: Longman/Pearson Education, 2000.

NORTON, B. Language, identity and the ownership of English. TESOL Quarterly. V. 31, N., Autumn, 1997.

MIGNOLO, W.D. The many faces of cosmo-polis: border thinking and critical cosmopolistanism. Public culture, 12 (3): 721-748, 2000.

MODIONO, M. Inclusive/exclusive? English as a lingua franca in European Union. World Englishes, Vol. 28, N.2, pp. 208-223, 2009.

OMONIYI, T.; SEXENA, M. Introduction. In: SAXENA, M.; OMONIYI, T. (Eds.) Contending with globalization in world Englishes. Toronto: Multilingual Matters, 2010.

PAIVA, V.L.M.O. A LDB e a legislação vigente sobre o ensino e a formação de professor de língua inglesa. In: STEVENS, C.M.T e CUNHA, M.J. Caminhos e Colheitas: ensino e pesquisa na área de inglês no Brasil. Brasília: UnB, 2003

PAKIR, A. English as a lingua franca: analyzing research frameworkds in international English, world Englishes and ELF. World Englishes, Vol 28, N.2, pp. 224-235, 2009. 
PARK, J.S.; WEE, L. The three circles redux: a market-theoretic perspective on World Englishes. In: Applied Linguistics. 30/3: 389-406, 2009.

PARKER, J. Collaborative academic work - writing in the disciplines. In: WALSH, LORRAINE E KAHN, PETER(Eds.).Collaborative working in higher education: the social academy. Routledge: New York, 2010.

PENNYCOOK, A. Nationalism, Identity and Popular Culture. In: Hornberger, N.; McKay, S. (Eds.). Sociolinguistics and Language Education. London: Multilingual Matters, UK, 2010.

PENNYCOOK, A. Rethinking origins and localization in global Englishes. In: SAXENA, M.; OMONIYI, T. (Eds.) Contending with globalization in world Englishes. London: Multilingual Matters, 2010.

PENNYCOOK, A. Global English's and transcultural flows. New York: Routledge, 2007.

PENNYCOOK, A. ELT and colonialism. In: CUMMINS, J; DAVISON, C (Eds), International handbook of English language teaching. New York: Springer, 2007.

PENNYCOOK, A. The myth of English as an international language. In: MAKONI, S.; PENNYCOOK, A (Eds.), Disinventing and reconstituting languages. New York: Multilingual Matters, 2007.

PENNYCOOK, A. Postmodernism in language policy. In: RICENTO, T. An introduction to language policy: theory and method. $4^{\text {th }}$ edition. New York: Blackwell, 2009.

PENNYCOOK, A. The Cultural Politics of English as an International Language, London: Longman, 1994. 
PHILLIPSON, R. Language policy and linguistic imperialism. In: RICENTO, T. (Eds.) An introduction to language policy: theory and method. $4^{\text {th }}$ edition. New York: Blackwell, 2009.

PHILLIPSON, R. Linguistic Imperialism. Oxford: Oxford University Press, 1992.

RAJAGOPALAN, K. The English language, globalization and Latin America: possible lessons from the 'outer circle'. In: SAXENA, M.; OMONIYI, T. (Eds.) Contending with globalization in world Englishes. Toronto: Multilingual Matters, 2010.

RAJAGOPALAN, K. The concept of 'World English' and its implications. ELT Journal. Oxford, v. 58, n. 2, p. 111-117, 2004.

RAJAGOPALAN, K. Repensar o papel da linguística aplicada. In: MOITA LOPES, L. P. (Org.). Por uma Linguística Aplicada Indisciplinar. São Paulo: Parábola, 2006.

RAJAGOPALAN, K. Politics of the English language. Claritas, v. 13, 2007.

RAJAGOPALAN, K. The English language, globalization and Latin America: possible lessons from the Outer Circle. In: Mukul Saxena, M; Omoniyi, T. (Eds.). Contending with Globalization in World Englishes. Bristol. UK: Multilingual Matters, 2010.

RANCIÈRE, J. A new logic of emancipation. In: BINGHAM, Charles; BIESTA, Gert J. J.; RANCIÈRE, Jacques (Eds.). Jacques Rancière: education, truth, emancipation. London: Continuum, 2010.

RANCIÈRE, J. On the shores of politics. London: Verson, 1995. 
ROCHA, C.H.. Práticas de letramento crítico, ensino plurilíngue e língua inglesa em contexto digital acadêmico universitário. Contexturas: ensino crítico de língua inglesa São Paulo: APLIESP, 2012.

SAID, E. Humanism and democratic criticism. New York: Columbia University Press, 2004.

RICENTO, T. An introduction to language policy: theory and method. $4^{\text {th }}$ edition. New York: Blackwell, 2009.

RICHARDS, J.; ROGERS, T. Approaches and methods in language teaching. Cambridge: Cambridge University Press, 2006.

RICOUER, J. P. O conflito das interpretações: ensaios de hermenêutica. Rio de Janeiro: Imago, 1978.

RIZVI, F.; LINGARD, B. Globalizing education policy. New York: Routledge, 2010.

ROJO, R. Letramentos múltiplos, escola e inclusão social. São Paulo: Parábola Editorial, 2009.

RYTHER, Catherine. "New" emancipation, education and the differences that make a difference. Philosophy of education, p. 178-180, 2008.

SAXENA, M.; OMONIYI, T. (Eds.) Contending with globalization in world Englishes. Toronto: Multilingual Matters, 2010.

SEIDLHOFER, B. Research perspectives on teaching english as a lingua Franca. Annual Review of Applied Linguistics. Vol. 24, p. 209-239, 2004. 
SEIDLHOFER, B. Common ground and different realities: world Englishes and English as a lingua franca. World Englishes, Vol. 28, No. 2, pp. 236-245, 2009a.

SEIDLHOFER, B.; BERNS, M. Perspectives on English as a lingua franca: introduction. World Englishes, Vol. 28, No. 2, pp. 190-191, 2009b.

SHAFIFIAN, F. Glocalization of English in world Englishes: an emerging variety among persian speakers of English. In: SAXENA, M.; OMONIYI, T. (Eds.) Contending with globalization in world Englishes. Toronto: Multilingual Matters, 2010.

SILVA, S.B. Da técnica à crítica: os letramentos críticos na formação de professores de inglês. Porto Alegre: Editora da Oficina, 2012.

SPIVAK, G. C. Scattered speculations on the subaltern and the popular, Postcolonial Studies, 8:4, 475 - 486, 2005.

SHOHAMY, E. Language policy: hidden agendas and new approaches.Rodlege, 2006.

SOUZA E SANTOS, B. Para além do Pensamento Abissal: Das linhas globais a uma ecologia de saberes, Revista Crítica de Ciências Sociais, 78, 3-46, 2007.

SOUZA, M.A.A. Investigando as questões globais e locais de dois cursos de Letras-Inglês Tese de doutorado. Programa de Pós-graduação em Estudos Linguísticos e Literários de Inglês. Universidade de São Paulo, 2011.

STREET, B. Social Literacies: Critical Approaches to Literacy in Education, Development and Ethnography. Longman; London, 1995. 
SNYDER, I. A new communication order: Researching literacy practices in the network society. Language and Education: An International Journal._15, 2 \& 3 , 117-131, 2001.

SPIVAK, G.C Scattered speculations on the subaltern and the popular. Postcolonial Studies, 8:4, 475 - 486, 2005.

SUÁREZ-OROZCO, N.M.; QIN-HILLIARD, D.B. Globalization, Culture and Education in the new millennium. Berkeley and Los Angeles: University of California Press, 2004.

TAKAKI, N.H. Leitura na formação de professores de inglês na escolar pública: a questão da reprodução de leitura no ensino de inglês. Jundiai-SP: Paco Editorial, 2011.

TODD, S. Towards an imperfect education: facing humanity, rethinking cosmopolitanism. Boulder: Paradigm Publisher, 2009.

TOLLEFSON, J.W. Critical theory in language policy. In: Ricento, T. An introduction to language policy: theory and method. $4^{\text {th }}$ edition. New York: Blackwell, 2009.

TOLLEFSON, J.W. Language planning in education. In: MAY, S.; HORNBERGER, N.H. (Eds.). Enclyclopedia of language and education, $2^{\text {nd }}$ edition, volume 1: Language policy and political issues in education. New York: Springer, 2010.

VATTIMO, G. Philosophy and the decline of the west. In: ZABALA, S. (Ed.) Nihilism and Emancipation: Ethics, Politics and Law. Columbia University Press, 2004. 
VATTIMO, Gianni. The end of modernity. Nihilism and hermeneutics in postmodern culture. Translated and with an introduction by Jon R. Snyder. Baltimore: The Johns Hopkins University Press, 1985.

. Philosophy and the decline of the west. In: ZABALA, S. (ed.) Nihilism and Emancipation: Ethics, politics and law. Columbia University Press, 2004.

WIDDOWSON, H. The ownership of English. In: COOK, G.; NORTH, S. (Eds.) Applied Linguistics: a reader. London: Routledge, 2010.

YANO, Y. English as an international lingua franca: from societal to individual. World Englishes, Vol. 28, No. 2, pp. 246-255, 2009.

ZAKHARIA, Z. (Re)constructing language policy in Shir'i school in Lebanon. In: MENKEN, K.; GARCIA, O. Negotiating language policy in schools: educators as policymakers. New York: Rotledge, 2010.

ZAMANATHAN, V. NORTON, B.; PENNYCOOK. A. In: SAXENA, M.; OMONIYI, T. Contending with globalization in world Englishes. Toronto: Multilingual Matters, 2010. 


\section{ANEXO 1:}

\section{REFERENCIAL CURRICULAR DO ESTADO DE MATO GROSSO DO SUL ENSINO MÉDIO - 2008 \\ LÍNGUA ESTRANGEIRA LÍNGUA INGLESA}

\section{COMPETÊNCIAS E HABILIDADES}

- Analisar e interpretar no contexto da interlocução.

- Reconhecer recursos expressivos das linguagens.

- Identificar manifestações culturais no eixo temporal, reconhecendo momentos de tradição e de ruptura.

- Emitir juízo crítico sobre as manifestações culturais.

- Identificar-se como usuário e interlocutor de linguagens que estruturam uma identidade cultural própria.

- Analisar metalinguisticamente as diversas linguagens.

- Ser capaz de compreender e produzir enunciados corretos e apropriados a seus contextos em língua estrangeira, fazendo uso de competências gramaticais, estratégicas, sociolinguísticas e discursivas.

- Saber distinguir norma culta de linguagem informal e, especialmente, os contextos de uso em que uma e outra devem ser empregadas. $O$ uso de gírias é apropriado, desde que o contexto assim o permita. É importante, pois, selecionar vocabulário adequado para o uso oral e escrito, a partir de um repertório que se amplia gradualmente ao longo de três anos de curso.

- Relacionar textos e seus contextos por meio da análise dos recursos expressivos da linguagem verbal, segundo intenção, época, local e 
estatuto dos interlocutores, fatores de intertextualidade e tecnologias disponíveis.

- Perceber características quanto à produção dos enunciados, os quais são reflexo da forma de ser e pensar de quem os produziu.

- Perceber o texto como um todo coeso e coerente, no qual certas expressões e vocábulos são empregados em razão de aspectos socioculturais inerentes à ideia que se quer comunicar. A percepção da coerência e da coesão textuais dar-se-á pela aquisição de competências e habilidades conquistadas em atividades de decodificação e interpretação de elementos intrínsecos à estrutura textual: conectivos (linkers), ordenação frasal (word order), uso de expressões idiomáticas, de phrasal verbs e de vocabulário adequado ao contexto comunicativo como, por exemplo, o emprego de palavras ligadas ao avanço tecnológico ou vocabulários próprios da esfera da informática.

- Compreender que a finalidade última da análise estrutural e organizacional da língua é dar suporte à comunicação efetiva e prática ou seja, a produção de sentido é a meta final dos atos da linguagem, quer se empreguem estratégias verbais, quer não-verbais.

- Perceber que o domínio de idiomas estrangeiros no ensino médio, ainda que se dê de forma parcial, permite acesso a informações diversificadas, a outras culturas e a realidades de diferentes grupos sociais. 


\section{PRIMEIRO ANO}

\section{1을 BIMESTRE}

$\checkmark$ Personal pronouns

$\checkmark$ Verb to be - (all forms); Short answers.

$\checkmark$ There is/There are

$\checkmark$ Demonstratives: This/That; these/those.

$\checkmark$ Definite and indefinite articles.

$\checkmark$ Interrogative words: who, where, what, how.

$\checkmark$ Simple Present -3 forms

$\checkmark$ Present continuous -3 forms.

\section{2을 BIMESTRE}

$\checkmark$ Simple present - Verb Do/does/don't/doesn't

$\checkmark$ Verb to have: present - affirmative.

$\checkmark$ Possessive adjectives.

$\checkmark$ Prepositions and adverbs of place.

\section{3ํㅗIMESTRE}

$\checkmark$ Plural of nouns.

$\checkmark$ Possessive case of nouns: Whose...?

$\checkmark$ Imperative.

$\checkmark$ Adverbs of frequency.

\section{4ํ BIMESTRE}

$\checkmark$ Verbs: like, need, want + infinitive. 
$\checkmark$ Modals: can/may.

$\checkmark$ Object pronouns.

Obs.: durante os 4 bimestres serão trabalhados os seguintes temas e vocabulários: The alphabet, music, Greetings, introductions, countries, nationalities, jobs or professions, cardinal and ordinal numbers, days of week, months of the year, seasons of the year, ages, dates, addresses, hours, family, objects, clothes, colours, foods and drinks, sports, subjects, parts of the house, parts of human body, like and dislikes 


\section{1음 BIMESTRE}

$\checkmark$ Prepositions: in, on, for, from

$\checkmark$ Prepositions: on, near, along, with, from, of, off, through, into, to, out of, across, beyond at

$\checkmark$ Possessive pronouns

$\checkmark$ Possessive case

$\checkmark$ To belong to

$\checkmark$ Text comprehension

\section{2을 BIMESTRE}

$\checkmark$ Past tense of regular verbs

$\checkmark \quad$ Irregular Verbs (Infinitive - Past tense - Participle)

$\checkmark$ Past tense of irregular verbs

$\checkmark$ Emprego de do, does, did, didn't.

\section{BIMESTRE}

$\checkmark$ Forma negativa: emprego de Don't / doesn't

$\checkmark$ Forma interrogativa no passado: emprego de Did

$\checkmark$ Forma negativa no passado: Did not (didn't)

$\checkmark$ Future tense: affirmative, negative and interrogative form

$\checkmark$ Condicional tense: affirmative, negative and interrogative form

$\checkmark$ Emprego do if 


\section{4ํㅗIMESTRE}

$\checkmark$ Personal pronouns: objective case

$\checkmark$ Degree of adjectives

$\checkmark$ Indefinites - Use of much / many / little / few

$\checkmark$ Question tag (com verbos auxiliares)

$\checkmark$ Question tag (com verbos não auxiliares)

$\checkmark$ Question tag: future conditional

$\checkmark$ Prepositions 


\section{TERCEIRO ANO}

\section{1을 BIMESTRE}

\footnotetext{
$\checkmark$ Prepositions (preposições e locuções prepositivas)

$\checkmark$ Comparative forms of adjectives

$\checkmark$ Superlative forms of adjectives

$\checkmark$ Future with going to

$\checkmark$ Future with present continuous
}

\section{BIMESTRE}

$\checkmark$ Future with Will

$\checkmark$ Conditional: Would

$\checkmark$ Past continuous tense

$\checkmark$ Modal verbs: must, have to, can, may, have to, should, ought to

$\checkmark$ Present perfect tense

$\checkmark$ Present perfect tense and Simple Past Contrasted

$\checkmark$ Present perfect with since or for

$\checkmark$ Present Perfect continuous

\section{BIMESTRE}

$\checkmark$ Reflexives Pronouns - Reciprocal Pronouns

$\checkmark$ Past Perfect

$\checkmark$ Relative pronouns (empregos dos principais relativos)

$\checkmark$ Passive voice (voz passiva e agente da passiva)

$\checkmark$ Emprego de since, for, also, too

$\checkmark$ Adverbs: place, doubt, affirmation, intensity

$\checkmark$ Adverbs: time, manner, frequency 


\section{4ํㅡㅁMESTRE}

$\checkmark$ Verbs: say - tell

$\checkmark$ Direct and indirect speech

$\checkmark$ Gerund

$\checkmark$ Revision 
ANEXO 2:

PARALELO ENTRE O REFERENCIAL CURRICULAR DO ESTADO DE MS E AS OCEM-MEC PARA O ENSINO DA LÍNGUA INGLESA (elaborado voluntariamente pela professora 2).

\begin{tabular}{|c|c|c|}
\hline & MS & MEC \\
\hline FINALIDADES & $\begin{array}{l}\text { Desenvolver o educando, assegurar- } \\
\text { lhe a formação indispensável para o } \\
\text { exercício da cidadania e fornecer-lhe } \\
\text { meios para progredir no trabalho e } \\
\text { em estudos posteriores. }\end{array}$ & $\begin{array}{l}\text { O aprimoramento do } \\
\text { educando como ser } \\
\text { humano, sua formação } \\
\text { ética, desenvolvimento de } \\
\text { sua autonomia intelectual e } \\
\text { de seu pensamento crítico, } \\
\text { sua preparação para o } \\
\text { mundo do trabalho e o } \\
\text { desenvolvimento de suas } \\
\text { competências para } \\
\text { continuar seu aprendizado. } \\
\text { (Art. 35) }\end{array}$ \\
\hline $\begin{array}{l}\text { ORGANIZAÇÃO } \\
\text { CURRICULAR }\end{array}$ & $\begin{array}{l}\text { Nortear o trabalho do professor de } \\
\text { forma dinâmica, objetivando uma } \\
\text { perspectiva interdisciplinar e } \\
\text { também garantir a apropriação do } \\
\text { conhecimento pelos estudantes. Os } \\
\text { conteúdos apresentados pretendem } \\
\text { ser vistos como meios de } \\
\text { constituição de competências, } \\
\text { privilegiando o raciocínio à } \\
\text { memorização, em que a teoria } \\
\text { deverá ser desenvolvida em } \\
\text { consonância com a experimentação, } \\
\text { possibilitando a formação de um } \\
\text { cidadão mais crítico, mais produtivo } \\
\text { e criativo. }\end{array}$ & $\begin{array}{l}\text { Base nacional comum, a } \\
\text { ser completada, em cada } \\
\text { sistema de ensino e } \\
\text { estabelecimento escolar, } \\
\text { por uma parte diversificada } \\
\text { que atenda } \\
\text { especificidades regionais e } \\
\text { locais da sociedade, da } \\
\text { cultura, da economia e do } \\
\text { próprio aluno. (Art. 26). } \\
\text { Planejamento } \\
\text { desenvolvimento orgânico } \\
\text { do currículo, superando a } \\
\text { organização por disciplinas } \\
\text { estanques. Integração e } \\
\text { articulação }\end{array}$ \\
\hline
\end{tabular}




\begin{tabular}{|c|c|c|}
\hline & & $\begin{array}{l}\text { documentos em processo } \\
\text { permanente } \\
\text { interdisciplinaridade } \\
\text { contextualização. }\end{array}$ \\
\hline $\begin{array}{l}\text { PARTICIPAÇÃO } \\
\text { NA } \\
\text { ELABORAÇÃO } \\
\text { DO } \\
\text { DOCUMENTO }\end{array}$ & $\begin{array}{l}\text { Profissionais em exercício, somando } \\
\text { ao trabalho que inicialmente havia } \\
\text { sido apresentado, sua experiência } \\
\text { junto ao } \\
\text { cidadão alvo de toda a mudança: } \\
\text { adolescentes, jovens e adultos. }\end{array}$ & $\begin{array}{l}\text { A proposta foi desenvolvida } \\
\text { a partir da necessidade } \\
\text { expressa em encontros e } \\
\text { debates com os gestores } \\
\text { das Secretarias de } \\
\text { Educação e aqueles que, } \\
\text { nas universidades, vêm } \\
\text { pesquisando e discutindo } \\
\text { questões relativas ao } \\
\text { ensino das diferentes } \\
\text { disciplinas. }\end{array}$ \\
\hline
\end{tabular}

